\title{
A IMPORTÂNCIA DAS NORMAS INTERNACIONAIS PARA O COMÉRCIO DA FRUTICULTURA BRASILEIRA
}

\section{Louise Antunes de Oliveira}

\author{
Dissertação apresentada à Escola Superior de \\ Agricultura "Luiz de Queiroz", Universidade de São \\ Paulo, para obtenção do Título de Mestre em Ciências, \\ Área de Concentração: Economia Aplicada.
}

P I R A C I C A B A

Estado de São Paulo - Brasil

Fevereiro - 2005 


\title{
A IMPORTÂNCIA DAS NORMAS INTERNACIONAIS PARA O COMÉRCIO DA FRUTICULTURA BRASILEIRA
}

\section{LOUise ANTUnes de OLIVEIRA}

Bacharel em Ciências Econômicas

Orientador: Profa. Dra. HELOISA LEE BURNQUIST

\begin{abstract}
Dissertação apresentada à Escola Superior de Agricultura "Luiz de Queiroz", Universidade de São Paulo, para obtenção do Título de Mestre em Ciências, Área de Concentração: Economia Aplicada.
\end{abstract}

P I R A C I C A B A

Estado de São Paulo - Brasil

Fevereiro -2005 


\section{Dados Internacionais de Catalogação na Publicação (CIP) DIVISÃO DE BIBLIOTECA E DOCUMENTAÇÃO - ESALQ/USP}

Oliveira, Louise Antunes de

A importância das normas internacionais para o comércio da fruticultura brasileira / Louise Antunes de Oliveira. - - Piracicaba, 2005.

$154 \mathrm{p}$.

Dissertação (Mestrado) - - Escola Superior de Agricultura Luiz de Queiroz, 2005.

Bibliografia.

1. Comércio - Brasil 2. Controle fitossanitário 3. Exportação 4. Fruta 5. Legislação de alimentos 6 . Normalização internacional I. Título

CDD 338.174

"Permitida a cópia total ou parcial deste documento, desde que citada a fonte - O autor" 


\section{DEDICO}

A Deus por me carregar no colo nos momentos mais difíceis de minha vida. As minhas queridas avós Maria José Scanelli (in memorian) e Bárbara Oliveira. e aos melhores pais que alguém pode ter, os meus, Luiz Carlos de Oliveira e Suely Antunes de Oliveira; pelas orações, pelo amor incondicional a mim dedicado, pelos sonhos que renunciaram para que eu pudesse realizar os meus e pela confiança que sempre depositaram em mim. 


\section{AGRADECIMENTOS}

Agradeço infinitamente a Deus que me deu a vida, caminhou comigo e me deu condições de chegar até aqui À minha família, especialmente aos meus pais e meus irmãos, Marcello e Matheus, que são as pessoas mais importantes na minha vida, sempre presentes nos meus momentos de alegria e de maiores dificuldades, me apoiando em todas as decisões, com palavras de incentivo, força moral e espiritual. Sem a fé e esse amor que recebo deles a.minha realização profissional e pessoal não seria possível.

À Profa. Heloisa Lee Burnquist, pela amizade e compreensão principalmente em momentos difíceis que passei nessa fase da minha caminhada. Sua orientação segura, ensinamentos e paciência ajudaram-me a crescer durante todo o período de elaboração desta dissertação.

Aos Profs. Ricardo Shirota, Silvia Helena Galvão de Miranda, e Mirian Rumenos Piedade Bacchi, pelas críticas e sugestões apresentadas por ocasião do exame de qualificação e pelo carinho com que me trataram. Gostaria de agradecer ainda de modo especial ao Prof. Ricardo Shirota, pelas suas palavras de pai nas horas em que delas eu. Agradecer por ter acreditado em mim e não ter permitido que eu desistisse no meio do caminho e à Profa. Silvia por ter sido uma estrela guia e um exemplo de pessoa e de profissional que levarei como modelo.

Aos professores do Departamento de Economia, Administração e Sociologia da ESALQ/USP, pelos ensinamentos recebidos. 
Aos funcionários do Departamento de Economia, Administração e Sociologia da ESALQ/USP, com destaque à Helena e Ligiana e de modo especial e muito carinhoso à Maieli por me emprestar seu amor de mãe, na ausência da minha, pela paciência, carinho e palavras de apoio nas horas desesperadora.

Aos pesquisadores da Embrapa Cláudio Buschinelli, Célia, Luiz Carlos Hermes, à coordenadora do Codex no Brasil Maria Aparecida Martinelli, pela ajuda, atenção e disponibilidade.

Aos amigos e companheiros Piracicabanos e com eterno carinho a: César Alves, Gustavo Sbrissia, Daniela Bacchi, Skarlet,Gustavo Costinha, Andréa gaúcha, Silvio, Nicolella, Leila, Ana Laura, Mariângela (Kutrali), Taciana, Carina, Naligia, Ana Maria Kefalas, Rose, Margarida, Farid 81 e 12, Jalaka, TDP, Lula, Todanu, Luciane gaúcha, Luciane Conte, Laura, Humberto, Moisés, Tziu, Kerlyng, Renata (Honda), Janete, Davi. As minhas amigas Daniela e Mariangela que mesmo de longe sempre torceram pela minha felicidade, às amigas de Bananal Paty, Bia, Beth e Vanessa.

Agradeço de modo especial aos amigos que dividiram mais de perto minhas conquistas, alegrias, tristezas e baladas enfim todos os momentos dessa caminhada: Thelma Harume Ohira (irmã gêmea), Luciana Bob (amiga incondicional), Andréa Ferro (irmã e conselheira mais centrada) Kuxis (Mariana, pela eterna amizade, paciência e ouvidos emprestados) Fran (irmãzinha caçula, que surgiu de última hora nessa jornada para me emprestar o gás que necessitava), Froid (Carlos, por ser meu irmão sempre presente).

À grande mestra e amiga Chemune Nader, pelos ensinamentos, palavras de carinho e correções à "toque de caixa" sem os quais não chegaria ao resultado final.

Ao meu companheiro, amigo e grande amor Rodolfo F.L. Aquino, pela compreensão, força, ajuda e principalmente seu amor paciente durante toda essa jornada. 
A cada chamada da vida o nosso coração relutante tem que estar pronto para a despedida e recomeço. Tem que estar pronto para dar outros laços sem tristeza, mas com coragem. Por isso é com carinho que eu digo obrigada a todas as pessoas. Que, direta ou indiretamente, removeram pedras e facilitaram o meu caminhar. Os momentos partilhados e as mais simples alegrias, guardarei para sempre no meu coração como preciosas lembranças. 


\section{SUMÁRIO}

Página

LISTA DE FIGURAS ............................................................................ ix

LISTA DE TABELAS .............................................................................. ix

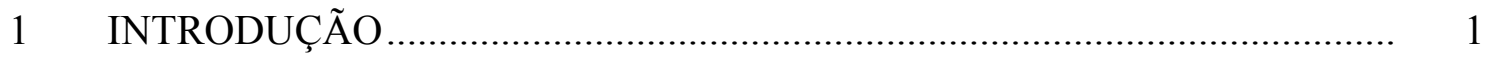

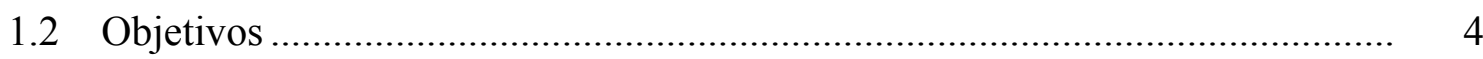

1.2.1 Objetivos específicos ........................................................................... 5

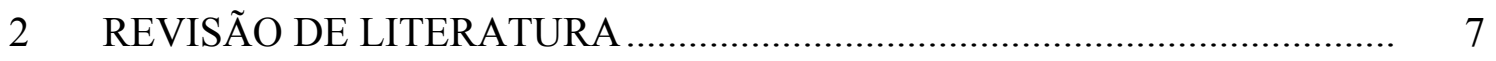

2.1 Importância da fruticultura para a economia brasileira................................... 7

2.1.1 Avanços tecnológicos e modernização da agricultura ...................................... 17

2.1.2 Histórico da produção integrada de frutas (PIF) ............................................ 19

2.1.5 Análise das principais Frutas do Sistema de Produção Integrada segundo dados tirados do Ministério da Agricultura e Embrapa, 2004, que já cumprem os objetivos, metas e começam a apresentar resultados................... 31

3.2 Protocolo europeu de boas práticas agrícolas (Eurep Gap) .......................... 41

2.3 Organismos internacionais importantes para a comercialização de frutas........ 45

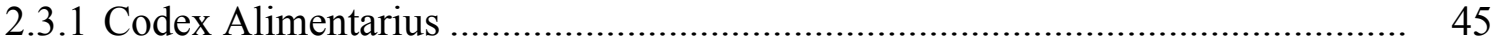

2.3.2 HACCP: análise de perigos e pontos críticos de controle (APPCC) sua importância no Brasil e no mundo .............................................................. 47

2.3.3 Animal and Plant Health Inspection Service (APHIS) ................................. 50

2.3.4 Food and Drugs Administration (FDA) .............................................. 53

2.4 Discussões sobre os acordos internacionais relevantes para a comercialização de frutas .................................................................... 53

2.4.1 Notificações: instrumento para transparência no comércio internacional .......... 59

2.4.2 Acordo TBT, descrição e importância ......................................................... 59 
2.4.3 Medidas técnicas relevantes no contexto da produção de frutas brasileiras ....... 65

2.4.4 Discussões sobre o Acordo SPS................................................................. 68

2.4.5 União Européia: exigências técnicas e sanitárias........................................... 73

2.4.6 Estados Unidos: exigências técnicas e sanitárias ............................................ 75

2.5 Conscientização mundial para normas......................................................... 77

2.5.1 A importância da utilização de conceitos para a normalização e certificação de alimentos entre os países ......................................................................... 79

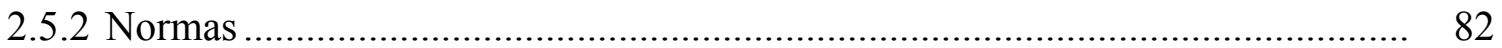

3 MATERIAL E MÉTODOS ................................................................. 93

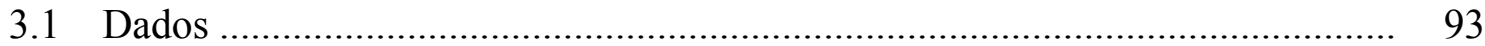

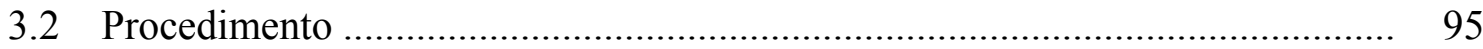

4 RESULTADOS E DISCUSSÃO ......................................................... 99

4.1 Análise das notificações e verificação de possíveis tendências no comercio

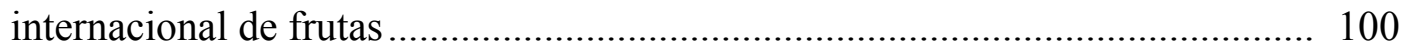

4.2 Análise da equivalência entre as normas e regulamentos das notificações e as normas do Codex Alimentarius .............................................................. 103

4.3 Análise da equivalência entre as normas e regulamentos das notificações e as normas do Codex Alimentarius para os Estados Unidos ............................ 105

4.4 Análise da equivalência entre as normas e regulamentos das notificações e as normas do Codex Alimentarius para a União Européia ............................ 108

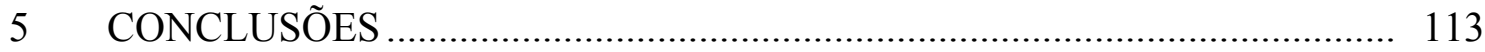

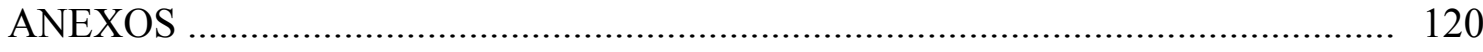

REFERÊNCIAS BIBLIOGRÁFICAS ....................................................... 147 


\section{LISTA DE FIGURAS}

Página

1 Taxa de crescimento (geométrica) das exportações de frutas do Brasil para o Mundo, num período compreendido entre 1996 e 2003 .................................. 13

2 Taxa de crescimento (geométrica) das exportações de frutas do Brasil para a União Européia, num período compreendido entre 1996 e 2003 ...................... 14

3 Taxa de crescimento (geométrica) de exportação de frutas do Brasil para os

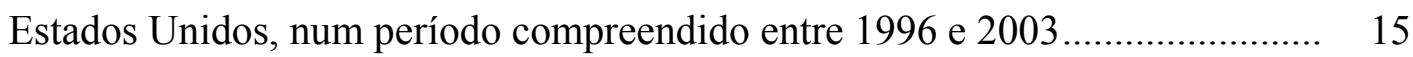

4 Exportação de frutas do Brasil para os Estados Unidos, União européia e Resto do Mundo em valor e volume ........................................................ 16

5 Processo de Aplicação do Programa PIF no Brasil ........................................ 24

6 Distribuição geográfica. de projetos MAPA/CNPq/Embrapa para frutas .......... 30

7 Evolução Anual do percentual das notificações feitas pelos Estados Unidos e União Européia para frutas em relação ao total das notificações feitas por estes países num período de janeiro de 1995 a outubro de 2004

8 Comparativo das notificações sobre frutas e LMR com objetivo: número de notificações feitas pelos Estados Unidos verificando-se quais constam no Codex e quais não constam no Codex, no período de 1995 a outubro de 2004 .. 107

9 Comparativo das notificações feitas pela União Européia referentes a frutas e LMR diferenciadas quanto a observação das que constam no Codex daquelas que não constam. Período de 1995 a outubro de 2004. 


\section{LISTA DE TABELAS}

Página

1 Comparativo das exportações brasileiras de frutas frescas 2001/2002/2003 em valor (milhões) US\$ FOB ..................................................................... 10

2 Comparativo das exportações brasileiras de frutas frescas 2001/2002/2003 em

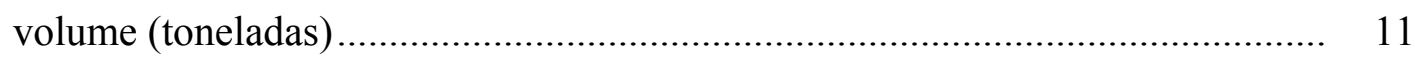

3 Evolução da produção integrada de frutas (PIF) no mundo.............................. 21

4 Principais frutas do sistema de produção integrada que já cumprem os

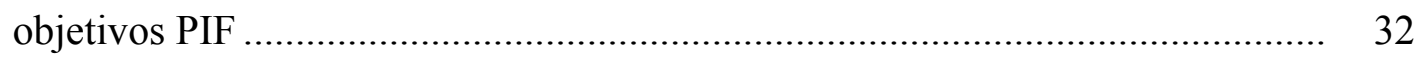

5 Indicadores de redução de agroquímicos - resultados parciais em (\%) .............. 35

6 Espécies de frutas priorizadas na PIF ................................................... 37

7 Quantificação dos dados das frutas aderidas ao programa PIF ......................... 38

8 Número de notificações SPS apresentadas à OMC pelos Estados Unidos e União Européia, classificadas como: total de notificações; notificações referentes a frutas; notificações referentes a LMR relacionadas a frutas.

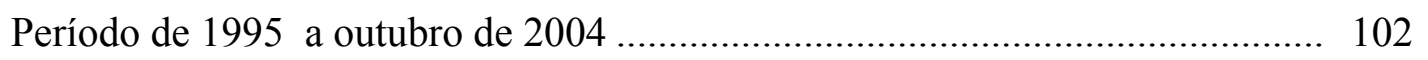

9 Notificações de LMR referentes a frutas apresentadas à OMC pelos Estados Unidos. Período de 1995 a outubro de 2004 ................................................. 106

10 Notificações de LMR referentes a frutas apresentadas à OMC pela União Européia. Período de 1999 a outubro de 2004 


\title{
A IMPORTÂNCIA DAS NORMAS INTERNACIONAIS PARA O COMÉRCIO DA FRUTICULTURA BRASILEIRA
}

\author{
Autor: LOUISE ANTUNES DE OLIVEIRA \\ Orientador: Profa. Dra. HELOISA LEE BURNQUIST
}

\section{RESUMO}

Padrões e regulamentações técnicas, sanitárias e fitossanitárias são utilizadas com o objetivo autêntico de mitigar o risco à vida e à saúde humana, das plantas e animais, além de preservar o meio ambiente. Além disso, constituem normas comuns para as características dos produtos, tal como a qualidade. No entanto, tem sido cada vez mais freqüente o emprego dessas medidas como instrumentos de política comercial para proteger mercados da importação estrangeira. Tem-se observado que esses requisitos técnicos vêm assumindo importância cada vez maior na restrição do acesso de produtos exportados in natura, como é o caso das frutas, pelos países em desenvolvimento para os mercados de países desenvolvidos. O presente trabalho buscou identificar a importância dessas exigências na definição do volume de exportações brasileiras de frutas para grandes mercados importadores, como é o caso dos Estados Unidos e da União Européia. O estudo enfocou, a princípio, a Produção Integrada de Frutas (PIF) brasileira, tendo-se conduzido uma análise descritiva, acompanhada da interpretação de seus objetivos, metas, contexto institucional, procedimentos e desenvolvimentos recentes. Essa avaliação visou destacar os principais aspectos que podem vir a estimular a exportação de frutas para mercados de países desenvolvidos, mais exigentes quanto a aspectos de qualidade e sanidade dos produtos. Concluiu-se que a forma de condução da 
produção integrada para as frutas no Brasil atende, em grande parte, aos requisitos exigidos nos principais mercados importadores. No entanto, para que a iniciativa venha a se constituir em uma forma efetiva para diferenciar os produtos nos mercados estrangeiros, ainda é necessário conquistar o reconhecimento internacional. Para a PIF, a análise sugere que embora importantes desenvolvimentos técnicos já tenham sido alcançados, falta um maior empenho político para que a iniciativa venha a ser reconhecida no âmbito legal por instituições internacionalmente reconhecidas, para a obtenção de um selo que ateste sua adequação à normalização internacional. Procurou-se também identificar tendências futuras para as exigências de segurança alimentar nos países selecionados, onde os consumidores são mais conscientes e exigentes quanto à qualidade e inocuidade dos alimentos. Para tanto, realizou-se um levantamento e análise das notificações apresentadas à OMC pelos EUA e União Européia, no âmbito do Acordo SPS/OMC, a partir de 1995, quando esse passou a prevalecer. Essa pesquisa enfocou as notificações referentes às frutas. Uma análise prévia indicou que as medidas referentes aos agroquímicos eram mais freqüentes na regulamentação internacional sobre a produção e comercialização de frutas. Foram selecionadas, portanto, as notificações relacionadas a limites máximos de resíduos (LMR), para fins de comparação com os padrões desenvolvidos pela Comissão do Codex Alimentarius, organismo de referência internacional. Essa avaliação buscou verificar se as exigências apresentadas pelos países importadores estavam de acordo com as normas estabelecidas por esse organismo. Os resultados indicaram que grande parte das notificações para frutas relacionadas a LMR, tanto para os EUA, como para a UE, continha medidas que não constavam no Codex, o que sugere que esses países vêm se empenhando, de forma pró-ativa no desenvolvimento de novas normas sanitárias e fitossanitárias. Isso foi interpretado como uma resposta às exigências dos respectivos mercados consumidores. Essa avaliação indicou que um importante gargalo da Produção Integrada de Frutas no Brasil, que deve ser observada pelos técnicos e regulamentadores, é a baixa compatibilidade entre o uso de agroquímicos e seus resíduos, aos padrões internacionalmente aceitáveis, devendo-se buscar um aumento na justaposição, tanto ao tipo do produto como ao nível em que esses são empregados na produção. A análise das 
notificações indicou ainda, que uma tendência da regulamentação fitossanitária dos países analisados enfatiza o uso de defensivos agrícolas. Isso permite concluir que um aspecto de importância fundamental para a expansão das exportações brasileiras de frutas para os principais mercados importadores, constitui-se no desenvolvimento de análises de risco, adequação e desenvolvimento de mecanismos para a certificação de que os produtos atendem aos requisitos estabelecidos pelos mercados internacionais. 


\section{THE IMPORTANCE OF INTERNATIONAL STANDARDS FOR TRADE OF THE BRAZILIAN FRUIT SECTOR}

Author: LOUISE ANTUNES DE OLIVEIRA

Adviser: Prof. Dr. HELOISA LEE BURNQUIST

\section{SUMMARY}

Sanitary and phytosanitary norms and regulations are used, in principle, with the legitimate objective to mitigating any risk to human, plant and animal health and life, while preserving the environment. In addition, these can be used to constitute common patterns for products, such as quality. However, it has been increasingly frequent the use of these measures as a trade policy instrument to protect market from imports. It has been observed that technical requirements have been increasingly important to restrict market access to exported fresh products, as fruits, by developing countries to developed countries markets. This work identifies the importance of these requirements to define the Brazilian export volumes of fruits to the major importing markets, such as the United States and European Union. The study primarily focused the Brazilian Integrated Fruit Production system in terms of its objectives, targets, institutional framework, and recent developments. This evaluation was conducted to stress the major aspects that may stimulate fruit exports for developed countries' markets, which are more demanding with respect to quality and sanitary aspects of the products. It was concluded that the procedures employed in Brazilian integrated food production fulfill a great part of the requirements of the most important importing markets mentioned above. However, the initiative will only become effective to differentiate products in the external markets, when international recognition is reached. The analysis suggests that despite reaching 
important technical developments, there is still a need of greater political efforts for the recognition of the initiative by international organizations. The work has also identified future trends for food safety requirements in the countries selected for the analysis, where consumers are more aware and demanding with respect to safety of food. This was conducted by researching the SPS notifications presented by the United States and European Union to the World Trade Organization (WTO), in the context of the SPS Agreement, starting from 1995, when it became effective. A previous analysis indicated that the measures related to limits upon agricultural chemicals were the most frequent objective of international regulation applied to production and trade of fruits. Therefore the notifications about Maximum Residual Levels (MRLs) were selected and compared to the patterns developed by the Commission of Codex Alimentarius, an institution for international reference, as established by the SPS Agreement of the WTO. The requirements presented by the importing countries in the notifications to the WTO were confronted with the Codex patterns. The results indicated that a great part of the notifications for fruits related to MRL, either for the USA or for the EU, included measures that were different from the Codex patterns. This was interpreted as a suggestion that these countries have been strongly involved in developing sanitary and phytosanitary norms in a proactive manner. This was considered a result of the demands and requirements of the countries' consumers. This evaluation indicated that an important bottleneck of the Brazilian Integrated Fruit Production, which should be observed by policymakers and technicians, is the low compatibility between the agrochemical products used and the authorized residuals, with the international accepted patterns. This requires efforts to match both, the product as the level by which these are applied in production. The analysis of the notifications also indicated that there is a trend in the phytosanitary regulation that emphasizes the use of agricultural chemicals. This leads one to conclude that an aspect of fundamental importance for the expansion of Brazilian fruit exports for the major importing markets is the development of mechanisms that certify that these products are according to their requirements. 


\section{INTRODUÇÃO}

A exportação de alimentos processados para países desenvolvidos tem-se apresentado como uma forma promissora para os países em desenvolvimento incrementarem suas vendas no mercado externo. Essa tendência vem sendo destacada por diversos autores ${ }^{1}$ que ressaltam, no entanto, os vários desafios que deverão ser enfrentados pelos países em desenvolvimento para ampliar sua participação nesses mercados.

De maneira geral, tem-se enfatizado que a penetração nesses mercados é condicionada à habilidade dos países em atender a padrões de segurança cada vez mais rigorosos impostos aos alimentos em países desenvolvidos (Athukorala \& Jayasuriya, 2003). Esses mesmos autores destacam diversos aspectos que têm dificultado o acesso a esses mercados pelos países em desenvolvimento. Tem-se indicado que, de maneira geral, os padrões adotados para produtos agro-alimentares nos países desenvolvidos são bem mais altos que os prevalecentes em países em desenvolvimento, envolvendo custos mais elevados. Além disso, as exigências referentes a aspectos de segurança e qualidade destes produtos têm-se alterado com freqüência, devido à maior velocidade com que novas tecnologias são desenvolvidas e adotadas, tanto para a obtenção de produtos mais adequados ao consumo, como para o controle da qualidade desses produtos nos vários estágios de produção, processamento e comercialização.

O desenvolvimento do conhecimento científico a respeito de riscos à saúde, melhorias na tecnologia de processamento, associado à elevada elasticidade renda dos

\footnotetext{
${ }^{1}$ Athukorala \& Jayasuriya (2003); Deodhar (2001); Henson et al. (2000)
} 
consumidores por padrões de segurança mais elevados, são aspectos que acentuam essas dificuldades (Athukorala \& Jayasuriya, 2003).

Ao longo das duas últimas décadas, a população vem mostrando uma maior conscientização quanto à importância das questões sociais e ambientais relacionadas à produção e comércio de produtos agrícolas. $\mathrm{O}$ atendimento às exigências quanto à forma como são obtidos os produtos deve ser comprovado.

Essa maior percepção do consumidor tem resultado em um aumento no número de padrões estabelecidos, bem como de iniciativas de certificação e/ou rotulagem (Dankers, 2003). A maior complexidade do sistema de normalização passou a envolver um número crescente de instituições de natureza diversificada, com a participação crescente da iniciativa privada e Organizações Não Governamentais (ONGs), além das instituições governamentais, essas últimas com poder de regulamentação.

Em suma, essas mudanças são positivas, pois devem estimular uma maior organização, transparência e eficiência na oferta de produtos agro-alimentares mais seguros para a alimentação humana. Tem sido comum, no entanto, a proposição de exigências bastante restritivas que suscitam fortes suspeitas quanto à sua legitimidade (Thornsbury et al., 1999; Thornsbury et al., 2004; Roberts et al., 1999; Jaffé \& Henson, 2004; Wilson, 2001; Jensen, 2001). Nesses casos, as exigências parecem ter o objetivo de dificultar o acesso aos mercados domésticos ao invés de se tornarem instrumentos para proteger a saúde humana, de plantas e de animais, com a devida fundamentação científica (Roberts et al., 1999; Jensen, 2001; Burnquist et al., 2002; Athukorala \& Jayasuriya, 2003). De fato, tem-se registrado que a redução do emprego de políticas de proteção comercial, comumente na forma de tarifas, negociada ao longo das várias rodadas do General Agreement on Tariffs And Trade (GATT), vem aumentando a visibilidade do emprego de instrumentos protecionistas e estimulando a restrição do uso de tarifas e de outras barreiras tradicionais ao comércio, tais como as quotas e as Restrições Voluntárias à Exportação (RVE). Essa maior transparência dos instrumentos 
protecionistas tradicionais, que tem sido proporcionada pelos acordos multilaterais firmados ao final da Rodada do Uruguai, estimulou, no entanto, o emprego de formas alternativas para manter - senão aumentar - a proteção aos mercados domésticos. As barreiras tradicionais tornaram-se progressivamente substituídas pelo uso de normas e regulamentos técnicos como instrumentos de política comercial.

Nesse contexto, as barreiras técnicas (BTs) foram se tornando um refúgio protecionista importante para os países que buscavam manter seus mercados protegidos da concorrência internacional (Jensen, 2001; Roberts et al., 1999).

A preocupação com o emprego progressivo de práticas protecionistas por meio de medidas de natureza técnica e sanitária levou os países membros da Organização Mundial do Comércio (OMC) a estabelecer, ao final da Rodada do Uruguai, em 1994, dois acordos - o Acordo sobre Barreiras Técnicas ao Comércio e o Acordo sobre Medidas Sanitárias e Fitossanitárias - ambos com o objetivo de estabelecer regras claras para impedir o emprego de medidas técnicas como instrumentos protecionistas. As oportunidades de explorar o desenvolvimento dos mercados de produtos agro-alimentares tornaram-se condicionadas, portanto, à observação desses dois acordos. Esses acordos legitimaram o direito de parceiros estabelecerem restrições baseadas em aspectos da segurança de alimentos e preocupações quanto à qualidade desses produtos.

No entanto, os benefícios que esses acordos podem trazer para os países em desenvolvimento, dependem da implementação de melhorias de seus sistemas de normas e controle de qualidade e segurança dos alimentos (Jensen, 2001). Esse aspecto é particularmente relevante para produtos que são consumidos in natura, como é o caso das frutas, que se constituem no objeto de análise do presente estudo. $\mathrm{O}$ trabalho representa uma contribuição para o desenvolvimento de análises aplicadas às barreiras "dentro das fronteiras", com ênfase na avaliação do impacto de padrões e regulamentações técnicas e sanitárias sobre as exportações brasileiras de frutas. $\mathrm{Na}$ definição do contexto analítico selecionou-se a Produção Integrada de Frutas brasileira, 
em função da importância que esse sistema de produção tem assumido nesse âmbito das exportações, conforme se caracteriza ao longo do trabalho.

A análise conduzida é de natureza qualitativa, visando identificar a compatibilidade desse programa com as exigências confrontadas com maior freqüência pelos exportadores de frutas nos principais mercados importadores brasileiros, que compreendem os países da União Européia (UE) e os Estados Unidos (EUA). Considerando-se que a questão das barreiras técnicas e sanitárias encontra-se em evolução, optou-se ainda por uma abordagem analítica envolvendo aspectos correntes e prospectivos.

A qualidade dos produtos agro-alimentares, particularmente os consumidos in natura, pode afetar a saúde dos consumidores. É importante ressaltar ainda, que a definição da qualidade do produto tem demandado a consideração dos procedimentos envolvidos nas várias etapas da produção, incluindo-se desde as atividades agrícolas, o processamento, industrialização, os serviços de comercialização até que o produto é adquirido pelo consumidor. Sabe-se que a qualidade duvidosa de um produto pode trazer prejuízos à saúde do consumidor, além de diminuir a credibilidade de empresas e países exportadores, que podem vir a sofrer, dessa forma, restrições de vendas no mercado internacional.

\subsection{Objetivos}

Em termos gerais, o presente estudo visa contribuir à análise sistemática de barreiras fitossanitárias para as exportações. Para tal, conduz-se uma análise qualitativa relacionada à Produção Integrada de Frutas (PIF) brasileira, no que tange à sua contribuição ao desenvolvimento do comércio internacional do setor. A análise da PIF conduzida neste trabalho compreende uma avaliação da compatibilidade e adequação desse programa com as exigências técnicas e sanitárias identificadas para o grupo dos 
principais países importadores das frutas brasileiras, compreendendo os Estados Unidos e os países da União Européia.

A avaliação é conduzida observando-se duas perspectivas: a adequação da PIF à solução de problemas correntes e problemas potenciais, sendo que esses últimos são avaliados como base nas exigências que vêm sendo desenvolvidas pelos países importadores enfocados pelo estudo.

\subsubsection{Objetivos específicos}

Os objetivos específicos do trabalho podem ser apresentados como:

1) Desenvolver uma análise crítica quanto à adequação da PIF, observando-se: (i) se a maneira como esse programa de produção integrada vem sendo implementada na fruticultura brasileira é adequada às exigências feitas pelos principais mercados importadores de frutas; (ii) as principais vantagens no contexto do comércio exterior e os desafios mais destacados confrontados pela indústria brasileira de frutas no processo de adequação à PIF.

2) Como respaldo para a análise da PIF, o estudo apresenta um detalhamento de organismos internacionais importantes para a comercialização de frutas, conceitos relevantes ao processo de normalização de produtos, descrição do processo de implantação da PIF e sua atual atuação no Brasil, visando mostrar os principais pontos de estrangulamento. Esse detalhamento é considerado útil para propor uma interpretação consolidada para a fruticultura, de modo que venha a constituir em referência básica para o desenvolvimento de análises sistemáticas no âmbito das barreiras fitossanitária ao comércio internacional.

3) Conduzir uma à análise das notificações apresentadas pelos EUA e países da UE à $\mathrm{OMC}$, considerando-as indicativas das tendências da normalização e principais preocupações prevalecentes nesses países com respeito às frutas. Essa investigação das notificações visa auxiliar a definição e o estabelecimento de ações corretivas. 
Concomitantemente, busca -se identificar as tendências em termos de regulamentações e padrões para a categoria Limite Máximo de Resíduos (LMR) relacionados a frutas, tanto pelo lado da demanda, quanto pelo lado da oferta, para o mercado internacional de frutas, visando a maior inserção do produto brasileiro nesse mercado.

4) Desenvolvimento de um contexto analítico teórico que sustenta a preocupação das autoridades em coibir o emprego de barreiras técnicas como medida protecionista, embora essa deva ser estimulada, sempre que estritamente necessária para proporcionar proteção à saúde humana, animal e das plantas, além da preservação do meio ambiente. 


\section{REVISÃO DE LITERATURA}

\subsection{Importância da fruticultura para a economia brasileira}

O Ministério da Agricultura, Pecuária e Abastecimento (MAPA), vem divulgando que o agronegócio é responsável por 33\% do Produto Interno Bruto (PIB), $42 \%$ das exportações totais e $37 \%$ dos empregos brasileiros. Estima-se que o PIB do setor chegue a US\$180,2 bilhões em 2004, contra US\$165,5 bilhões alcançados no ano de 2003. Entre 1998 e 2003, a taxa de crescimento do PIB agropecuário foi de 4,67\% ao ano. No ano de 2003, as vendas externas de produtos agropecuários renderam ao Brasil US\$ 36 bilhões, o que equivale a pouco menos que $22 \%$ do PIB no ano representando um superávit de US\$25,8 bilhões (Brasil, 2004a).

Num período de dez anos (1993 a 2003), o país dobrou o faturamento com as vendas externas de produtos agropecuários e teve um crescimento superior a $100 \%$ no saldo comercial. Esses resultados levaram a Conferência das Nações Unidas para o Comércio e Desenvolvimento (Unctad) a prever que o país será o maior produtor mundial de alimentos na próxima década (Brasil, 2004a).

O Brasil é um dos líderes mundiais na produção e exportação de vários produtos agropecuários. Já assume a posição de o maior primeiro produtor mundial e exportador nos mercados de café, açúcar, álcool e sucos de frutas. Além disso, lidera o ranking das vendas externas de soja, carne bovina, carne de frango, tabaco, couro e calçados de couro. As projeções indicam que o país também será, em pouco tempo, o principal pólo mundial de produção de algodão e biocombustíveis (feitos a partir de cana-de-açúcar e óleos vegetais) milho, arroz, cacau, castanhas, nozes, suínos e 
pescados, além das frutas frescas, objeto deste trabalho. As frutas frescas vem mostrando ser uma das atividades capaz de assegurar um percentual significativo de volume de produção e da pauta de exportação brasileira (Brasil, 2004b).

A produção mundial de frutas em 2004 foi em torno de 540,0 milhões de toneladas, correspondendo ao montante de US\$162,0 bilhões. O Brasil, depois da China e Índia (55,6 milhões e 48,1 milhões de toneladas, respectivamente), é o $3^{\circ}$ maior produtor de frutas do mundo (38 milhões de toneladas ano 2003) (Brasil, 2004a).

Verifica-se que a fruticultura tem se mostrado um importante setor para o agronegócio brasileiro. Com um superávit de US\$ 267 milhões em 2003, o setor ocupa uma área de 3,4 milhões de hectares. Atualmente, o mercado interno absorve 21 milhões de toneladas/ano e o excedente exportável é de cerca de 17 milhões de toneladas, segundo o Ministério da Agricultura, Pecuária e Abastecimento (Brasil, 2004a). Em 2003, as vendas externas de frutas frescas alcançaram US\$ 335,3 milhões, com um aumento de 39\% em comparação aos US\$ 241 milhões obtidos em 2002. Neste ano, devem crescer em torno de $15 \%$, chegando a US\$ 375 milhões, tentando atingir uma meta de exportação de 1 bilhão de dólares em frutas frescas até 2010. (Brasil, 2004b).

Pode-se analisar a evolução das exportações de frutas brasileiras nos últimos anos, reforçando a afirmação acima mencionada, nas Tabelas 1 e 2 . 
Tabela 1. Comparativo das exportações brasileiras de frutas frescas 2001/2002/2003 em valor (milhões) US\$ FOB

\begin{tabular}{|c|c|c|c|c|c|}
\hline Fruta & $\begin{array}{c}\text { Jan. a Dez. } \\
2003\end{array}$ & $\begin{array}{c}\text { Jan. a Dez. } \\
2002\end{array}$ & $\begin{array}{c}\text { Jan. a Dez. } \\
2001\end{array}$ & $\begin{array}{c}\text { Variação (\%) } \\
2003 / 02\end{array}$ & $\begin{array}{c}\text { Variação (\%) } \\
\text { 2002/01 }\end{array}$ \\
\hline Manga & $73.394,4$ & $50.849,0$ & $50.814,0$ & 44,3 & 0,1 \\
\hline Uva & $59.938,7$ & $33.788,8$ & $21.563,0$ & 77,4 & 57,0 \\
\hline Melão & $58.315,5$ & $37.778,0$ & $39.297,0$ & 54,4 & 4,0 \\
\hline Maçã & $37.833,6$ & $31.403,1$ & $18.139,0$ & 20,5 & 73,0 \\
\hline Banana & $30.013,3$ & $33.573,9$ & $16.036,0$ & $-10,6$ & 109,0 \\
\hline Mamão & $29.213,7$ & $21.623,8$ & $18.503,0$ & 35,1 & 17,0 \\
\hline Limão & $16.948,5$ & $9.891,1$ & $7.635,0$ & 71,4 & 30,0 \\
\hline Laranja & $13.347,7$ & $8.125,1$ & $27.538,0$ & 64,3 & 70,0 \\
\hline Tangerina & $6.197,1$ & $7.016,1$ & $6,697,0$ & $-11,7$ & 5,0 \\
\hline Melancia & $3.473,1$ & $2.756,8$ & $2.299,0$ & 26,0 & 20,0 \\
\hline Abacaxi & $2.848,4$ & $1.790,8$ & $3.408,0$ & 59,1 & 47,0 \\
\hline Figo & $1.673,9$ & $1.092,8$ & $1.086,0$ & 53,2 & 1,0 \\
\hline Outras & 561,7 & 416,1 & 190,0 & 35,0 & 119,0 \\
\hline \multicolumn{6}{|l|}{ frutas } \\
\hline Outros & 389,9 & 63,2 & 17,0 & 516,5 & 274,0 \\
\hline \multicolumn{6}{|l|}{ Cítricos } \\
\hline Framboesa & 340,1 & 307,1 & 372,0 & 10,8 & 17,0 \\
\hline Morango & 318,0 & 133,0 & 413,0 & 139,0 & 68,0 \\
\hline Abacate & 301,9 & 276,4 & 345,0 & 9,2 & 20,0 \\
\hline Coco & 138,4 & 61,2 & 125,0 & 126,3 & 51,0 \\
\hline Airelas e & 29,4 & 23,2 & 69,0 & 23,0 & 65,0 \\
\hline \multicolumn{6}{|l|}{ Mitrilos } \\
\hline Pêra & 14,2 & 10,8 & 4,0 & 30,6 & 180,0 \\
\hline Pomelo & 4,6 & 7,3 & 16,0 & $-36,9$ & 56,0 \\
\hline Kiwi & 2,8 & 20,5 & 11,0 & $-86,7$ & 93,0 \\
\hline
\end{tabular}


Tabela 1. Comparativo das exportações brasileiras de frutas frescas 2001/2002/2003 em valor (milhões) US\$ FOB

\begin{tabular}{lrrccc}
\hline Fruta & Jan. a Dez. & Jan. a Dez. & Jan. a Dez. & Variação (\%) & Variação (\%) \\
& 2003 & 2002 & 2001 & $2003 / 02$ & $2002 / 01$ \\
\hline Ameixa & 2,1 & 21,8 & 5,0 & $-90,3$ & 315,0 \\
Pêssego & 239,0 & 10,9 & 6,0 & $-97,8$ & 85,0 \\
Groselha & 19,0 & 0 & & - & \\
Total & $335.301,8$ & $241.042,4$ & $214.590,0$ & 39,1 & 12,0 \\
\hline
\end{tabular}

Fonte: Brasil (2004f)

Tabela 2. Comparativo das exportações brasileiras de frutas frescas 2001/2002/2003 em volume (toneladas)

\begin{tabular}{lrrccc}
\hline Fruta & Jan. a Dez. & Jan. a Dez. & Jan. a Dez. & Variação (\%) & Variação (\%) \\
& \multicolumn{1}{c}{2003} & \multicolumn{1}{c}{2002} & \multicolumn{1}{c}{2001} & $2003 / 02$ & \multicolumn{2}{c}{$2002 / 01$} \\
\hline Manga & $133.329,7$ & $103.598,0$ & $94.291,0$ & 28,7 & 10,0 \\
Uva & $37.600,7$ & $26.357,0$ & $20.660,0$ & 42,7 & 28,0 \\
Melão & $149.758,4$ & $98.689,9$ & $99.434,0$ & 51,7 & 1,0 \\
Maçã & $76.465,8$ & $65.927,2$ & $35.786,0$ & 16,0 & 84,0 \\
Banana & $220.770,8$ & $241.038,1$ & $105.112,0$ & $-8,4$ & 129,0 \\
Mamão & $39.492,3$ & $28.540,8$ & $22.804,0$ & 38,4 & 25,0 \\
Limão & $34.011,6$ & $21.826,1$ & $14.811,0$ & 55,8 & 47,0 \\
Laranja & $68.015,6$ & $40.373,6$ & $139.582,0$ & 68,5 & 71,0 \\
Tangerina & $18.311,7$ & $19.553,7$ & $17.258,0$ & $-6,4$ & 13,0 \\
Melancia & $16.364,1$ & $12.250,5$ & $13.698,0$ & 33,6 & 11,0 \\
Abacaxi & $12.096,1$ & $8.660,4$ & $14.457,0$ & 39,7 & 40,0 \\
Figo & 815,3 & 621.7 & 633,0 & 31,2 & 2,0 \\
Outras & 629,1 & 444.8 & 238,0 & 41,5 & 87,0 \\
frutas & & & & &
\end{tabular}


Tabela 2. Comparativo das exportações brasileiras de frutas frescas 2001/2002/2003 em volume (toneladas)

\begin{tabular}{lrrrcc}
\hline Fruta & $\begin{array}{r}\text { Jan. a Dez. } \\
\text { Jan. a Dez. }\end{array}$ & Jan. a Dez. & Variação (\%) & Variação (\%) \\
& \multicolumn{1}{c}{2003} & \multicolumn{1}{c}{2002} & \multicolumn{1}{c}{2001} & $2003 / 02$ & \multicolumn{1}{c}{ 2002/01 } \\
\hline Outros & 456,8 & 54.4 & 1,0 & 739,8 & 4021,0 \\
Cítricos & & & & & \\
Framboesa & 58,1 & 59,6 & 64,0 & $-2,6$ & 6,0 \\
Morango & 129,6 & 67,0 & 228,0 & 93,1 & 71,0 \\
Abacate & 514,8 & 596,6 & 606,0 & $-9,6$ & 6,0 \\
Coco & 604,7 & 166,6 & 384,0 & 262,5 & 57,0 \\
Airelas e & 4,5 & 4,1 & 10,0 & 11,2 & 58,0 \\
Mitrilos & & & & & \\
Pêra & 7,7 & 5,2 & 3,0 & 47,2 & 64,0 \\
Pomelo & 18,9 & 23,4 & 49,0 & $-19,0$, & 53,0 \\
Kiwi & 7,6 & 34,9 & 13,0 & $-78,2$ & 168,0 \\
Ameixa & 4,7 & 19,7 & 5,0 & $-76,1$ & 264,0 \\
Pêssego & 200,0 & 19,1 & 8,0 & $-99,0$ & 131,0 \\
Groselha & 22,0 & 0,0 & & - & \\
Total & $809.468,7$ & $668.906,0$ & 580,1 & 21,0 & 15,0 \\
\hline
\end{tabular}

Fonte: Brasil (2004f)

O comportamento das exportações brasileiras de frutas para o mundo e para os principais importadores, UE e EUA, pode ser observado considerando-se a taxa de crescimento (geométrica) das exportações totais de frutas frescas do Brasil, plotadas nas Figuras 1,2 e 3.

Verifica-se que o valor das exportações totais de frutas do Brasil para mundo, no período 1996 a 2003, oscilou na faixa dos US\$ 300 a US\$ 500 milhões, com 
uma taxa de crescimento de $6,6 \%$ ao ano e de $166,0 \%$ acumulado no período considerado, sendo que no ano de 2003 foi um dos mais expressivos.

A análise da taxa de crescimento em volume apresenta uma tendência mais significativa, de 300 mil toneladas e chegando a quase 900 mil toneladas no período, com uma taxa de crescimento anual de $17,23 \%$ e um crescimento total no período considerado de $356,7 \%$.

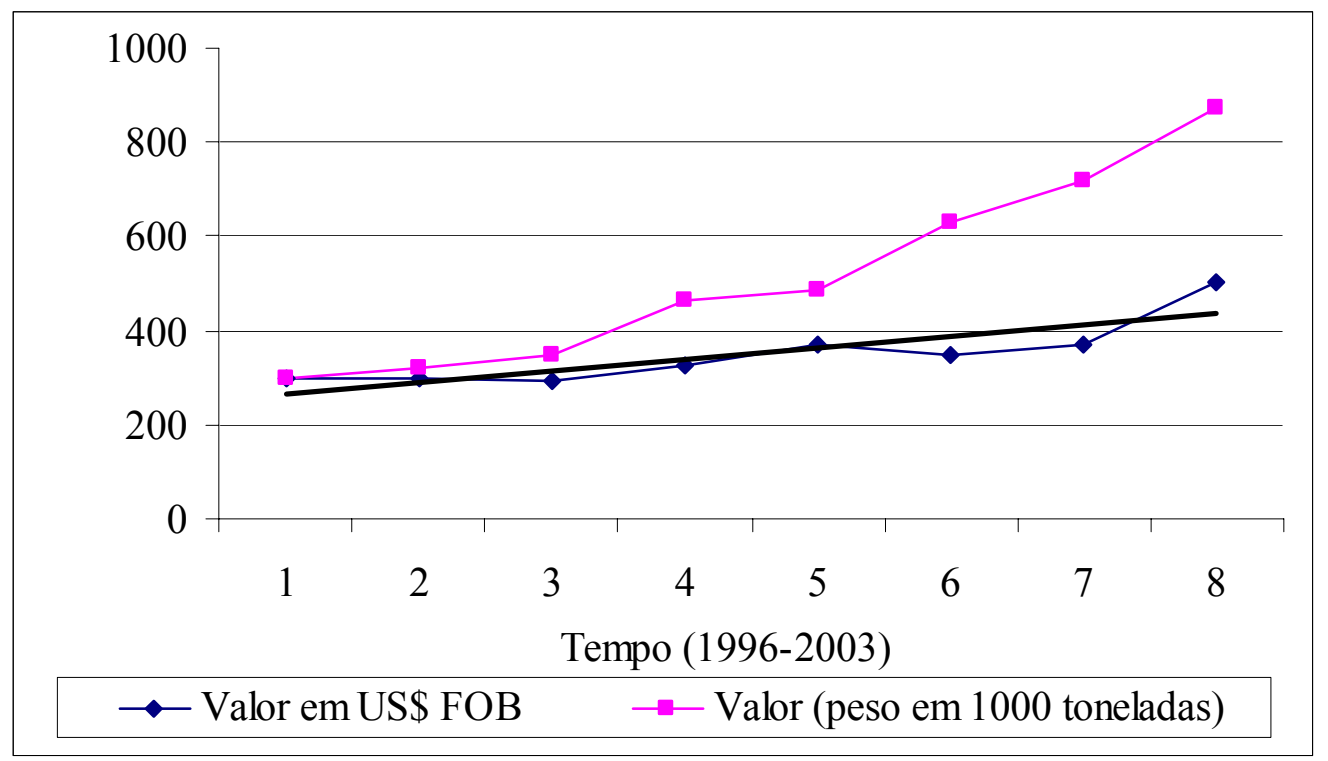

Figura 1 - Taxa de crescimento (geométrica) das exportações de frutas do Brasil para o Mundo, num período compreendido entre 1996 e 2003

Fonte: Brasil (2004e)

No que se refere às exportações de frutas frescas do Brasil para a União Européia, a taxa de crescimento anual foi de $14,36 \%$ e o crescimento total do período foi de $292,61 \%$. Em volume, as taxas de crescimento anual e total, foram de $17 \%$ e $365,82 \%$, respectivamente. 


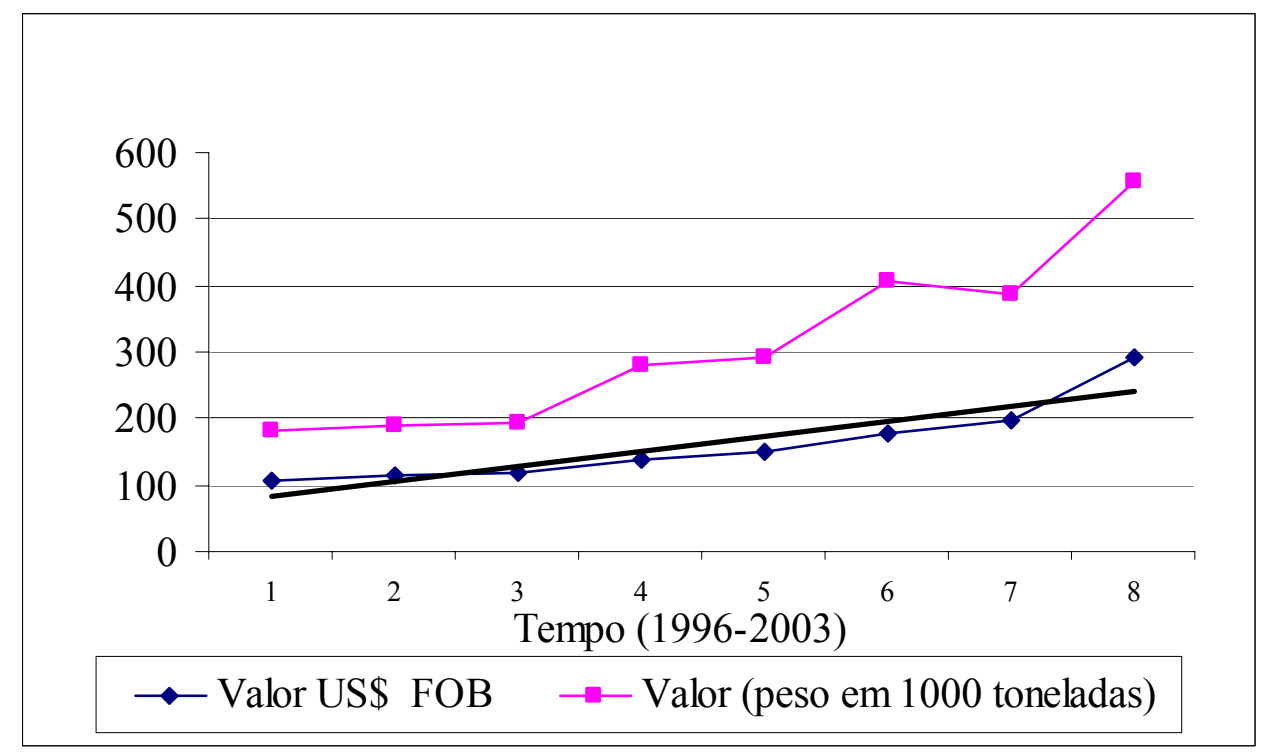

Figura 2 - Taxa de crescimento (geométrica) das exportações de frutas do Brasil para a União Européia num período compreendido entre 1996 e 2003

Fonte: Brasil (2004e)

Em relação aos Estados Unidos, o comportamento das taxas de crescimento das exportações de frutas brasileiras, diferencia-se pouco do verificado para União Européia e para o Resto do Mundo. Percebe-se uma taxa de crescimento anual com valor negativo $(-0,9 \%)$ e a taxa de crescimento total no período, é bastante inferior relativamente às da União Européia e Mundo, sendo de 92\%. Já a taxa de crescimento em volume também é inferior, mas não tanto quanto a taxa em valor, apresentando um valor anual de $12 \%$ e uma taxa de crescimento acumulada no período analisado de $255 \%$. 


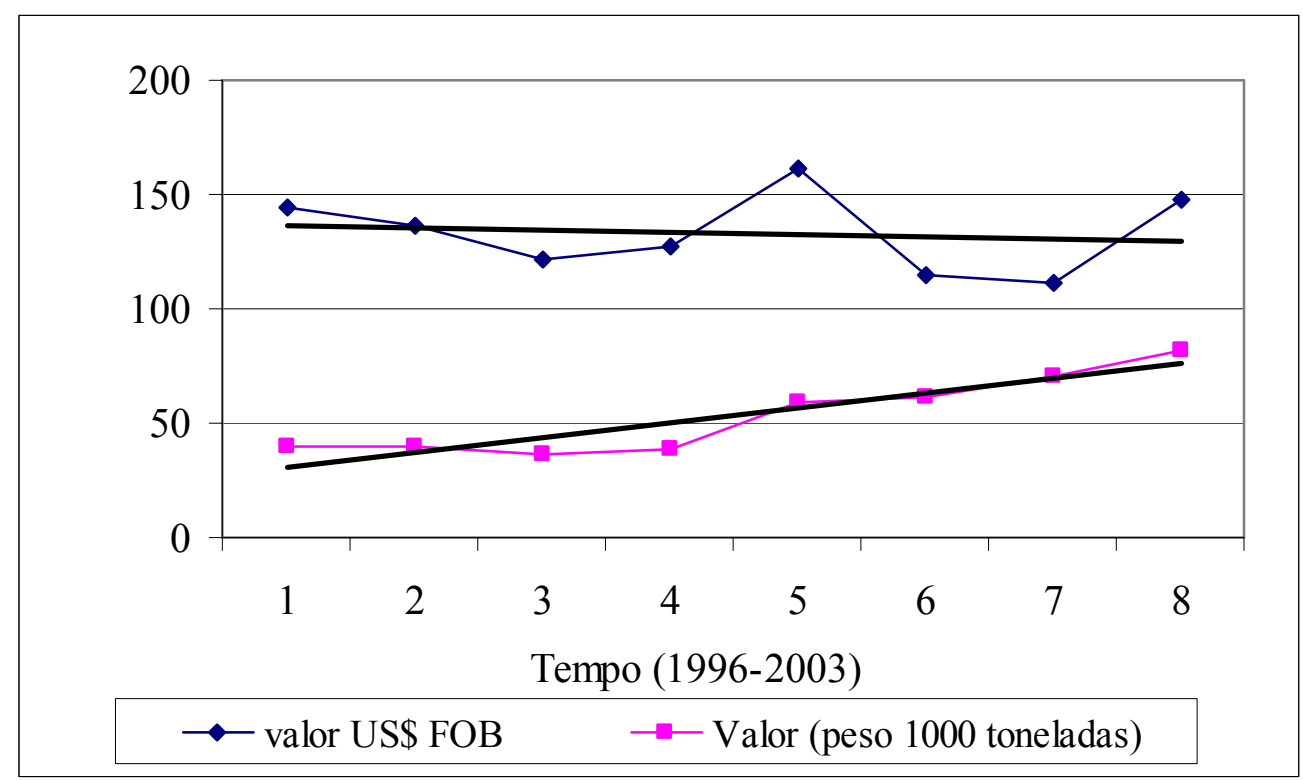

Figura 3 - Taxa de crescimento (geométrica) de exportação de frutas do Brasil para os Estados Unidos, num período compreendido entre 1996 e 2003

Fonte: Brasil (2004e)

Verifica-se, a partir dos dados acima mencionados, que uma média de $65 \%$ das exportações totais de frutas brasileiras vai para países da União Européia, como mostra a Figura 4. 


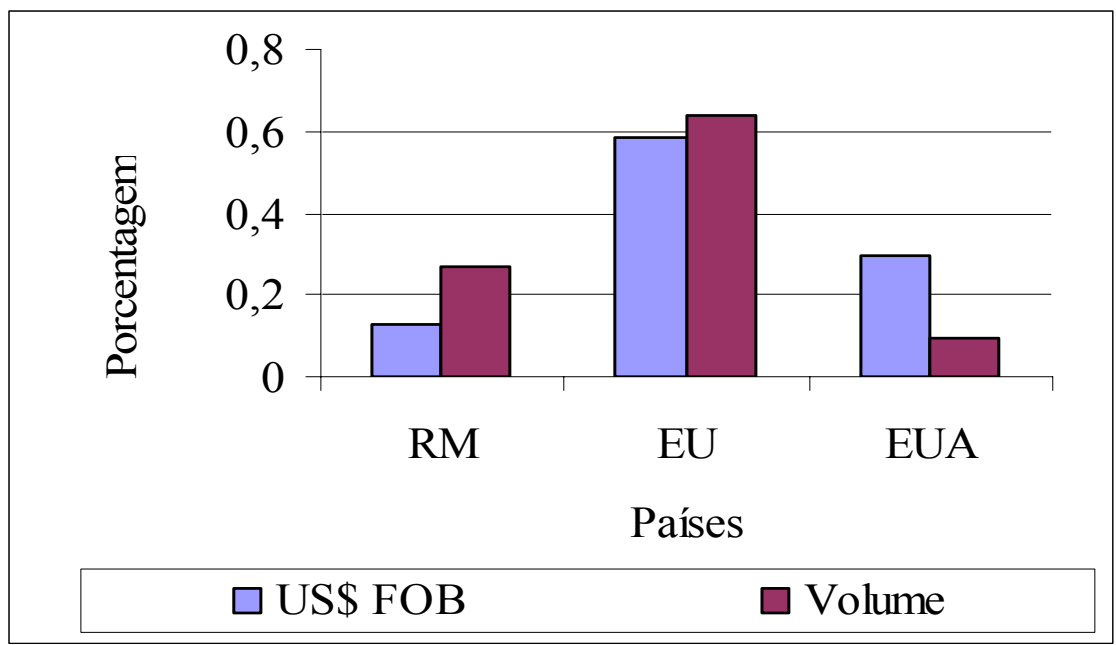

Figura 4 - Exportação de frutas do Brasil para os Estados Unidos, União Européia e Resto do Mundo em valor e volume

Fonte: Brasil (2004g)

Considerando que esse potencial brasileiro na área de fruticultura, pode levar a uma ampliação de participação do mercado internacional, o MAPA e os produtores do setor passaram a investir em um sistema de cultivo de frutas de alto padrão de qualidade e sanidade que é a Produção Integrada de Frutas (PIF). Essa sistemática visa assegurar que os produtos sejam obtidos empregando-se práticas ecologicamente corretas, minimizando efeitos indesejáveis devido ao uso de agroquímicos, para aumentar a proteção do meio ambiente e melhorar a saúde humana. (Embrapa, 2004a). 


\subsubsection{Avanços tecnológicos e modernização da agricultura}

Considerando produtos agrícolas como vendas importantes do século $\mathrm{XX}$, o "pacote tecnológico" da Revolução Verde ${ }^{2}$ criou uma estrutura de crédito rural subsidiado e, paralelamente, uma estrutura de ensino, pesquisa e extensão rural associadas a esse modelo. A partir da década de 60, no entanto esse modelo de agricultura, começou a dar sinais de sua exaustão devido aos impactos que passaram a ser associados às práticas introduzidas tais como: desflorestamento, diminuição da biodiversidade, erosão e perda da fertilidade dos solos, contaminação da água, dos animais silvestres e dos agricultores por agrotóxicos, que passaram a ser decorrentes da produção agrícola (Ehlers, 1993).

Com o avanço tecnológico e a agilidade das informações, os consumidores passam por um processo de conscientização para aquisição de alimentos, com requisitos de qualidade do produto, além de exigências de caráter ambiental, social e econômica. Porém, particularmente nos países em desenvolvimento, percebeu-se uma continuidade do avanço da agricultura convencional, com o agravamento dos danos ambientais.

No início dos anos 70, a oposição ao padrão produtivo agrícola convencional concentrava-se em um amplo conjunto de propostas "alternativas", movimento que ficou conhecido como "agricultura alternativa". Em 1972 foi fundada em Versalhes, na França, a International Federation on Organic Agriculture (IFOA), cujas principais atribuições passaram a ser a troca de informações entre as entidades associadas, a harmonização internacional de normas técnicas e a certificação de alimentos, alimentos in natura e produtos orgânicos (Ehlers, 1993).

\footnotetext{
2 "Revolução Verde", implantada na América Latina em meados da década de 1960, defendeu a idéia de se adaptar plantas de clima temperado a regiões de clima tropical e subtropical, por meio de controle e modificação biológica, determinando rendimento, estrutura física e períodos de maturação, baseadas na forte aplicação de insumos industrializados, irrigação e mecanização agrícola, fomentado pelo alarde de uma crise mundial de produção de grãos alimentícios, forte aumento da população mundial, uma perspectiva pessimista quanto à disponibilidade de alimentos no mundo e uma possível redenção econômica dos países do $3^{\circ}$ mundo por meio da exportação em massa desses grãos. A realidade foi a da desigualdade social e o aparecimento de problemas irreversíveis no tocante à sustentabilidade econômica e ecológica da produção agrícola no longo prazo.
} 
De modo geral, é possível afirmar que, na década de 80 , o interesse da opinião pública pelas questões ambientais e a adesão de alguns pesquisadores ao movimento alternativo, sobretudo em função dos efeitos adversos dos métodos convencionais, tiveram alguns desdobramentos importantes no âmbito da ciência e da tecnologia.

As características mais marcantes destes desdobramentos são: a busca de fundamentação científica para as suas propostas técnicas e, no caso da agroecologia o firme propósito de valorizar os aspectos sócio-culturais da produção agrícola. A principal meta da agroecologia é resolver os problemas da sustentabilidade (Ehlers, 1993).

Em 1992, na Conferência Mundial da ECO92, no Rio de Janeiro - Brasil, desenvolveu-se um conceito formal para sustentabilidade, manifestando uma nova ordem mundial que expressa a vontade das nações em conciliar (ou reconciliar) o desenvolvimento econômico e o meio ambiente, e integrar a problemática ambiental ao campo da economia. Mais do que um conceito que orienta de maneira imediata a ação e decisão, a sustentabilidade manifesta, a princípio, uma problemática de aspectos múltiplos (científico, político e ético) oriunda da emergência de problemas ambientais em escala mundial e principalmente da percepção do risco subjacente. Emergem com isso, os processos de certificação ambiental dos produtos agrícolas, com diversas iniciativas para certificar partindo de organizações não governamentais, que garantem a qualidade dos alimentos.

Globalmente, pode-se dizer que a agroecologia surgiu como uma nova visão de mundo levando a agricultura a um novo patamar supondo uma diferenciação social. $\mathrm{O}$ recurso às tecnologias sustentáveis requer um investimento em equipamentos e técnicas específicas e por um acesso privilegiado à informação. Nesse ponto, cabe a seguinte questão: "Estarão todas as formas de agricultura tanto em países desenvolvidos como em países em desenvolvimento, em posição de igualdade diante de tais desafios?” Embora algumas iniciativas semelhantes venham sendo desenvolvidas, como é o caso da 
PIF, que teve sua origem na Europa em 1974 e começou a ser introduzida no Brasil em 1998, trata-se de um assunto complexo que merece uma análise mais detalhada quanto à compatibilidade e abrangência das iniciativas existentes.

\subsubsection{Histórico da produção integrada de frutas (PIF)}

Conforme mencionado acima, a PIF surgiu como uma extensão do Manejo Integrado de Pragas (MIP), quando se considerou que tal sistema de produção era necessário para reduzir o uso de pesticidas e obter maior respeito ao ambiente, no Norte da Itália nos anos 70. Nesta época, os produtores de maçãs da região verificaram que os ácaros da macieira tinham adquirido resistência aos acaricidas. Com auxilio de pesquisadores, esses produtores iniciaram um programa de manejo integrado de ácaros, usando monitoramento e técnicas alternativas de controle. A experiência levou os produtores, a decidirem que deveriam promover mudanças profundas em todo o sistema, dado que as práticas isoladas para o controle de uma praga ou doença não se mostraram eficazes. Com isso, passou-se a desenvolver práticas culturais integradas. Essas iniciativas passaram a ser registradas, historicamente, como base para a PIF (Fachinello, 2004b).

A adesão à PIF teve um grande impulso a partir dos anos 80 mantendo-se nos anos 90, pelo resto do mundo, devido à demanda pelos consumidores das frutas sadias, com qualidade e sem agrotóxicos. Desenvolveu-se uma consciência ecológica visando proteger e conservar o meio ambiente. Dessa forma, o uso de produtos químicos, de moléculas ativas de fertilizantes capazes de poluir o solo, água, ar e deixar resíduos tóxicos na cadeia alimentar foram drasticamente restritos (Fachinello, 2004b).

O mercado internacional vem sinalizando que o aspecto qualitativo e o respeito ao meio ambiente na produção de bens são aspectos que podem afetar o acesso a determinados mercados, particularmente em países desenvolvidos. Os principais países importadores das frutas brasileiras, representados pela UE e EUA e as principais frutas 
exportadas pelo Brasil (manga, uva, maçã, melão banana), sinalizam o grande potencial de mercado a ser explorado. $\mathrm{O}$ acesso a esses mercados tem sido condicionado, no entanto,, às seguintes transformações: (i) consumidores mais exigentes, principalmente os europeus, quanto à qualidade e sanidade das frutas e hortaliças, requerendo produtos sem resíduos de agroquímicos e (ii) cadeias de distribuidores e de supermercados europeus, representados pelo EUREPGAP ${ }^{3}$, que têm pressionado exportadores de frutas e hortaliças para o estabelecimento de regras de produção que levem em consideração: resíduos de agroquímicos, meio ambiente e condições de trabalho e higiene (Andrigueto, 2004).

No Brasil, o MAPA, criou o Programa de Desenvolvimento da Fruticultura (PROFRUTA) como prioridade estratégica, e estabeleceu como objetivo principal elevar os padrões de qualidade e competitividade da fruticultura brasileira ao patamar de excelência requerido pelo mercado internacional. A base desse programa foi o sistema integrado de produção, sustentabilidade do processo, expansão da produção e emprego e renda (Brasil, 2004b).

\footnotetext{
${ }^{3}$ EUREPGAP: O protocolo europeu EUREPGAP leva em consideração as Boas Práticas Agrícolas (BPAs) e APPCC. O manejo integrado de pragas, MIP e a produção integrada (PI) são consideradas pelo EUREPGAP como essenciais para promover a sustentabilidade das produções agrícolas, com objetivo de garantir a segurança alimentar dos produtos in natura destinados ao mercado europeu.
} 
Tabela 3. Evolução da Produção Integrada de Frutas (PIF) no mundo

\begin{tabular}{lcc}
\hline Local & Ano de início & Espécies \\
\hline Europa & 1974 & Macieira e pereira \\
Argentina & 1993 & Macieira e pereira \\
África do Sul & 1994 & Macieira e pereira \\
Nova Zelândia & 1996 & Macieira \\
USA & 1997 & Macieira e pereira \\
Chile & 1998 & Macieira e pereira \\
Brasil & 1998 & Macieira \\
Brasil & 1999 & Pessegueiro \\
\hline
\end{tabular}

Fonte: Embrapa (2004a)

Uma das ações prioritárias do PIF no Brasil consiste no desenvolvimento de um sistema de produção orientada e de livre adesão por parte dos produtores e empacotadoras, que poderá ser utilizado como importante diferencial para concorrer nos mercados nacional e internacional. No Brasil, o MAPA em parceria com o Conselho Nacional de Desenvolvimento Científico e Tecnológico (CNPq) viabilizou a implementação de 57 projetos em diferentes pólos de produção de frutas, dos quais 27 projetos são de Produção Integrada de Frutas, 25 de matrizeiros e 5 em fitossanidade de suporte a PIF (Embrapa, 2004c).

As frutas cultivadas no sistema de produção integrada vão para o mercado com um selo de conformidade, atestando a sua qualidade e sanidade. Na prática, tem-se verificado que desde que foi implantada, a PIF do Brasil permitiu uma redução de $63 \%$ no uso de agrotóxicos nos pomares de manga; de 50\% no mamão; de 32\% na uva; e de 30\% na maçã.(Embrapa, 2004a). Esse é um aspecto de extrema importância uma vez que o limite dos resíduos em cultivos vem-se mostrando como um aspecto de grande importância para o consumidor. 
Os princípios básicos que regem a PIF estão amparados, principalmente, na elaboração e desenvolvimento de normas e orientações de comum acordo entre os agentes da pesquisa, ensino e desenvolvimento (como o $\mathrm{CNPq}$ ); extensão rural e assistência técnica (como a Embrapa); associações de produtores; base produtiva; e autoridades do país (como o MAPA), por meio de um programa multidisciplinar, objetivando com isto, assegurar que a produção da fruta seja conduzida de acordo com a sistemática definida pelo Modelo de Avaliação da Conformidade adotado.

\subsubsection{A produção integrada de frutas (PIF) no Brasil}

A implementação da PIF no Brasil teve um desafio de ser interpretada e aplicada com 04 pilares de sustentação (organização da base produtiva, sustentabilidade, monitoramento do sistema e informação). A Produção Integrada está colocada no ápice da pirâmide como o nível mais evoluído em organização, tecnologia, manejo e outros, num contexto onde os patamares para inovação e competitividade são estratificados por níveis de desenvolvimento ${ }^{4}$, como mostrado na Figura 5.

Para atingir o nível 4, Produção Integrada, os produtores brasileiros primeiramente passaram por um processo de conscientização, desafio assumido pela Embrapa, que buscou conseguir o maior número possível de adesão de produtores ao programa. A princípio, os produtores visados eram os que adotavam o que se chama de modo convencional de produção, que não envolve, necessariamente, a atenção a regras de Boas Práticas Agrícolas (BPA).

Com o apoio da Embrapa Meio Ambiente os produtores começaram a adotar as BPA, que inclui o Procedimento Padrão de Higiene Operacional (PPHO), exigidos atualmente, pelos maiores mercados importadores de frutas. A partir desse passo, formou-se uma equipe técnica que passou a verificar e inspecionar todo o fluxo de

\footnotetext{
${ }^{4}$ BUSCHINELLI, C.; MAGANHOTTO, C.M.; HERMES, L.C. (Embrapa Meio Ambiente, Jaguariúna).
} Comunicação pessoal, 2004. 
produção, conhecido como sistema de Análise de Perigos e Pontos Críticos de Controle (APPCC), identificado como o nível 2 do processo.

No nível 3, o produtor passou a ser monitorado pelas exigências dos mercados importadores, usando o Sistema Codex Alimentarius como referência o uso de Limites Máximos de Resíduos (LMR), aumentando seu cuidado com a produção,de forma a atender a cada exigência específica do importador (europeu ou americano).

Como a União Européia é o importador brasileiro de frutas mais significativo, conforme mostrado na Figura 4, a PIF brasileira apresenta uma forte preocupação em se adequar às exigências européias, buscando atender não apenas ao EUREPGAP, como ao BRC (Consórcio de varejistas ingleses) ${ }^{5}$ e à UNE (espanhola).

5 Britsh Retail Consortium (BRC). O Consórcio de Varejistas Ingleses tem sido inestimável no fortalecimento de entendimentos de detalhes essenciais que afetam indústrias inglesas, ajudando-as a desenvolver continuamente os serviços oferecidos aos consumidores e varejistas. Sendo assim, o porta-voz das indústrias inglesas faz um elo entre Governo e varejistas, onde o governo apóia tanto grande como pequenos industriais. 


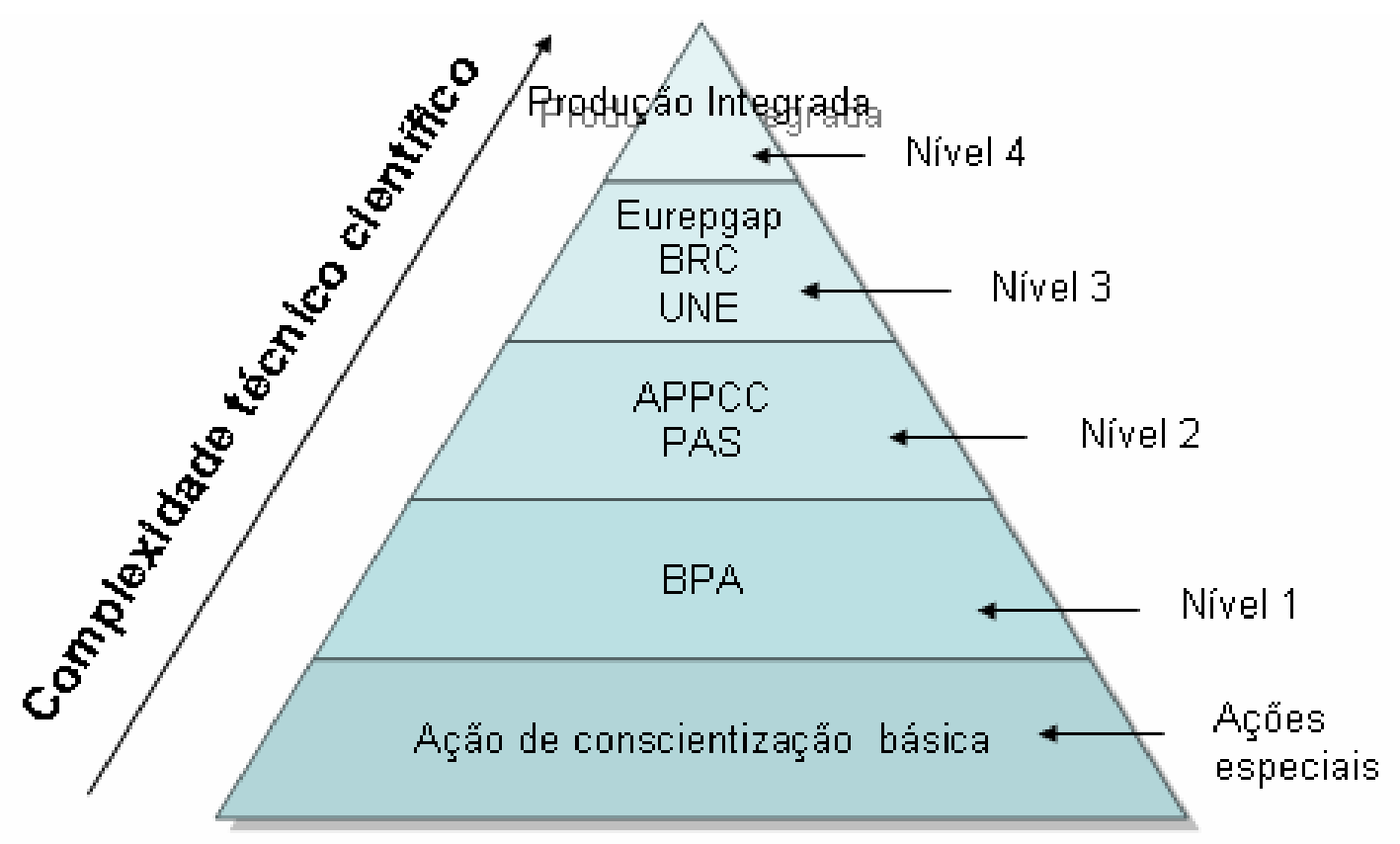

Figura 5 - Processo de aplicação do Programa PIF no Brasil

Fonte: Embrapa (2004c)

Nota: EUREP - GAP: Protocolo Europeu de Boas Práticas Agropecuárias

BRC : Britsh Retail Consortium

UNE: conjunto de normas espanholas para certificação de produtos ${ }^{6}$

APPCC: Análise de Perigos e Pontos Críticos de Controle

PAS: Programa de Alimentos Seguros

BPA: Boas Práticas Agropecuárias

Um exemplo das exigências da UE caracterizou-se pela proibição das exportações de maçãs produzidas através de sistema convencional, a partir de 2003. A partir de 2005, esse banimento deve se estender a outras espécies. Atualmente, na Suíça e Dinamarca, quase já não existem mercados para as frutas produzidas seguindo um sistema convencional (Andrigueto, 2004).

\footnotetext{
${ }^{6}$ ASSOCIACIÓN ESPAÑOLA DE NORMALIZACIÓN Y CERTIFICACIÓN (AENOR). Normas. http://www.aenor.es/desarrollo/normalizacion/quees/descripcion.asp (31 Jan. 2005)
} 
O Brasil já possui seu Marco Legal da Produção Integrada composto de Diretrizes Gerais e Normas Técnicas Gerais para a Produção Integrada de Frutas oficializada por intermédio da Instrução Normativa $N^{\circ} 20$, publicada no Diário Oficial da União (DOU), no dia 15 de outubro de 2001, Regulamento de Avaliação da Conformidade (RAC), Definições e Conceitos do programa PIF, Regimento Interno da Comissão Técnica-CTPIF, Formulários de Cadastro (CNPE) e outros componentes de igual importância, documentos estes, resultantes da parceria entre o MAPA, o Instituto Nacional de Metrologia, Normalização e Qualidade Industria (INMETRO) e o Ministério do Desenvolvimento, Indústria e Comércio Exterior (MDIC) (Moraes, 2002).

\subsubsection{Funcionamento do Programa PIF no Brasil}

O programa PIF, iniciado em 1998 no Brasil, constitui-se em uma parceria do MAPA com o Inmetro, para estabelecer critérios de segurança alimentar, social, ambiental e econômico, para a produção frutícula. Esses visam impedir que o país venha a se deparar com barreiras técnicas e fitossanitárias nos grandes mercados consumidores: Estados Unidos e União Européia.

Dessa forma, a PIF objetiva também estabelecer uma relação de confiança para o consumidor de que o produto está conforme os requisitos especificados em Normas Técnicas Específicas para cada espécie frutífera. Conceitualmente, é um sistema de produção de frutas de alta qualidade, priorizando princípios baseados na sustentabilidade, aplicação de recursos naturais e regulação de mecanismos para substituição de insumos poluentes, utilizando instrumentos adequados de monitoramento dos procedimentos e a rastreabilidade de todo o processo. Isso o torna economicamente viável (pelo fato de reduzir os custos com agrotóxicos), ambientalmente correto e socialmente justo. A adoção do programa PIF traz importantes vantagens tanto para o produtor/empacotadora, como para o consumidor. 
A adesão ao programa é voluntária, porém requer que o produtor esteja disposto a seguir as normas técnicas da PIF. As maiores vantagens da adesão ao PIF para o produtor, podem ser expressas, segundo Andrigueto (2004), como:

1) Agregação de valor à fruta (e/ou produto final processado);

2) Padronização e aumento da qualidade da fruta;

3) Organização da base produtiva;

4) Valorização do produto à maximização dos lucros;

5) Redução dos custos de produção decorrentes de desperdícios e uso de insumos agrícolas e através da maior eficiência do manejo dos recursos naturais;

6) Obtenção de um produto diferenciado, já que as frutas produzidas através da Produção Integrada possuem preferência de compra dentro das grandes cadeias de comercialização em relação aos sistemas convencionais, Oliveira (2002).

Os fatores mencionados levam a uma participação no mercado de forma competitiva, mantendo a permanência do produtor no mercado, podendo até aumentar fatia de mercado (interno e externo).

Além das vantagens para o consumidor, que passa a ter oferta de frutas saudáveis e com qualidade, as tecnologias utilizadas na produção agridem menos o meio ambiente e a saúde humana. A tecnologia empregada assegura que os Índices de Resíduos sejam mantidos de acordo com os padrões nacionais e internacionais, assegurando, ainda, a sustentabilidade do processo de produção e pós-colheita, o que é um aspecto de grande relevância ${ }^{7}$.

${ }^{7}$ BUSCHINELLI, C.; MAGANHOTTO, C.M.; HERMES, L.C., op. cit., p.22. 
O Inmetro é responsável pela seqüência do processo, realizando o credenciamento (acreditação) dos órgãos que avaliam a conformidade PIF, com o objetivo de avaliar viabilidade técnica e econômica do Sistema de Produção Integrada.

Quando implementada, um dos objetivos da produção integrada de frutas era de que a partir de 2003, já fossem comercializadas frutas com o selo PIF, que representaria a garantia do sistema de controle de acompanhamento completo, desde semeadura até a fase final, com a rastreabilidade do produto. Esperava-se que o programa fornecesse ao Brasil título de maior fornecedor de frutas tropicais do mundo, (Inmetro, 2004).

A produção de frutas no Brasil desenvolveu-se aplicando insumos químicos, de forma intensa visando o aumento de produção. O novo cenário mercadológico passa a visar a manutenção da capacidade competitiva.

Em 1997, a Embrapa Uva e Vinhos aplicou a PI desencadeando o processo para aprimorar segmentos da cadeia produtiva da maçã, lançando a primeira versão das Normas de Produção Integrada de Frutas, com o objetivo de avaliar a viabilidade técnica e econômica do Sistema de Produção Integrada da maçã. Foi um projeto pioneiro, que levou a um bom desempenho técnico, juntamente com as pressões do mercado externo, que se tornava cada vez mais competitivo e seletivo.

Outras cadeias começaram a organizar as produções integradas, que privilegia a sustentabilidade ambiental e segurança alimentar, fatores que são prérequisitos para realizar conversão de propriedade em sistema convencional para sistemas agroecológicos de produção (Embrapa, 2004a).

O programa de produção Integrada de Frutas no Brasil foi baseado nas normas do EUREPGAP (Embrapa, 2004a). Atualmente tem-se o apoio do Ministério da Agricultura para pêssego, uva, manga, citros, mamão e banana, que representa um salto qualitativo, como desenvolvimento de sistemas pós-colheita, certificação de origem e rastreabilidade de produção. Tornando-se necessário adequar a oferta a novos padrões de 
qualidade e sanidade dos mercados externos e internos, e rede varejista, com procedimentos padronizados de pós-colheita e implantação de certificação de origem e de rastreabilidade a produção.

Segundo Moraes (2002), a PIF pode ser tornar um "mercado" estratégico para a produção agroecológica no Brasil.

No país, os objetivos do programa agregam:

i) produção econômica de frutas e aumento da qualidade;

ii) métodos ecologicamente corretos, dando ênfase à proteção do meio ambiente;

iii) minimizar efeitos secundários indesejáveis e uso de agroquímicos;

iv) proporcionar frutas de qualidade interna e externa superior, para competir no mercado interno e externo;

vi) diminuir a resistência de pragas, diminuindo assim o uso de agrotóxicos;

vii) melhorar a imagem do produtor perante a sociedade;

viii) aumento da consciência ecológica.

Outro importante exemplo dentro da PIF é o estímulo dado pela Embrapa Meio Ambiente na região Nordeste, subsidiando a produção integrada de frutas quanto à avaliação e gestão ambiental das unidades de produção. O Vale do São Francisco é o maior produtor de mangas e uvas finas de mesa do país. Para este desafio é necessário obter conhecimentos e informações sobre o processo produtivo, que possam ser facilmente recuperadas mediante sistemas informatizados de rastreabilidade em tempo real $^{8}$

${ }^{8}$ MAGANHOTO, C.M. (Embrapa Semi-Árido, Petrolina). Comunicação pessoal, 2004. 
O Laboratório de Gestão Ambiental da Embrapa Meio Ambiente foi pioneiro no país na busca do conceito de rastreabilidade dos itinerários técnicos das cadeias produtivas para o agronegócio hortifrutícola, por meio de um código universal denominado Ecoterra (Embrapa, 2004b)

A PIF é uma forma moderna de se praticar agricultura, com enfoque principal apoiado no conhecimento holístico do sistema agrário adotado pela Unidade de Produção, equilibrando o uso de métodos biológicos, químicos e a tecnificação, considerando a produção e qualidade do meio ambiente, a rentabilidade e as demandas sociais.

O método utilizado pela Embrapa Meio Ambiente, para a tipificação dos produtores que desejem aderir à PIF, é baseado no nível tecnológico e faz uso de métodos estatísticos multivariados para a obtenção dos agrupamentos pretendidos. Isto é, os agrupamentos devem atender aos diferentes estágios dos produtores rurais, abrangendo desde aqueles que ainda não têm tecnificação, até os que já detém um estágio de alto desenvolvimento tecnológico ${ }^{9}$. A intenção é elevar o nível tecnológico dos produtores, utilizando ações compatíveis com cada um, permitindo que ele escale os degraus necessários (mostrados na Figura 5) para chegar à qualidade total no campo. Esta forma de abordagem permitirá que os produtores se adequem a PIF com mais facilidade do que nas atuais condições.

Segundo a Embrapa, tal fato é aliado às tecnologias empregadas, que permite a obtenção de ciclos sucessivos de produção, de forma que ocorre colheitas em qualquer época do ano, com produtividades acima da média nacional juntamente com um importante incentivo relacionado à legislação de cultivares, cuja implementação tem atraído o capital privado, principalmente das grandes cadeias de distribuição, para atividades de pesquisa.

${ }^{9}$ BUSCHINELli, C.; MAGANHOTTO, C.M.; HERMES, L.C., op. cit., p.22. 
O melhoramento e a obtenção de novas variedades do cultivo de frutas, associados à irrigação, tem permitido estender o período de produção praticamente para o ano inteiro, possibilitando o desenvolvimento desses cultivos em regiões como o Nordeste brasileiro e contribuindo para alterar seu perfil de região com problemas (para o cultivo agrícola) para região com soluções para o cultivo de frutas. No Nordeste, a fruticultura tem potencial para alcançar importância econômica com avanço tecnológico.

Verifica-se a evolução da implantação da PIF no Brasil, na Figura 6, a partir de um projeto inicial de reeducação do MAPA, Embrapa junto aos produtores com adesão voluntária por parte destes. A Figura 6 também nos mostra a localização dos principais matrizeiros (de frutas) e de projetos de fitossanidade.

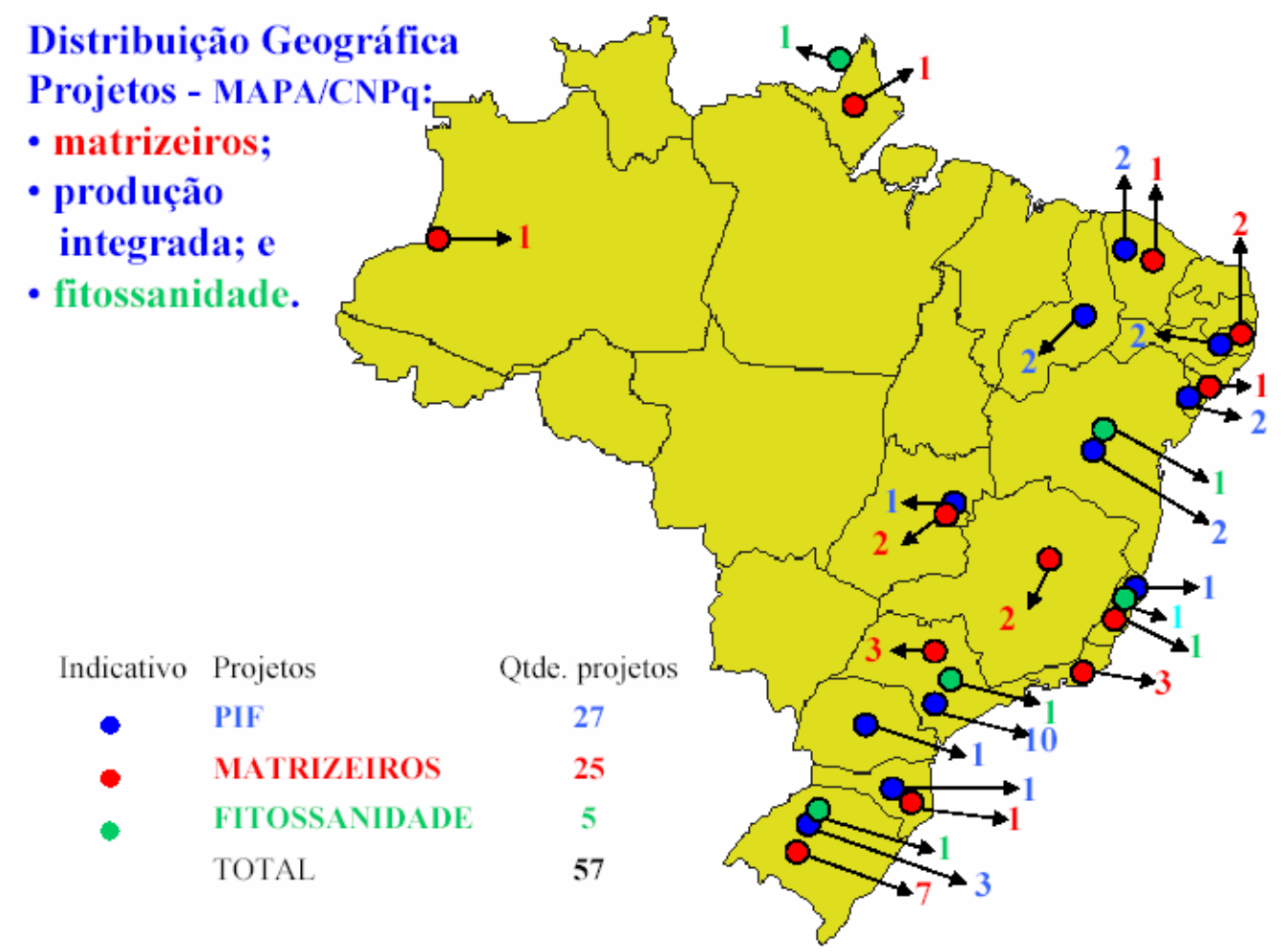

Figura 6 - Distribuição geográfica de projetos MAPA/CNPq/Embrapa para frutas Fonte: Andrigueto (2004) 


\subsubsection{Análise das principais Frutas do Sistema de Produção Integrada segundo dados tirados do Ministério da Agricultura e Embrapa, 2004, que já cumprem os objetivos, metas e começam a apresentar resultados}

A implantação do Sistema de Produção Integrada para maçã, manga, uva, citrus, pêssego, banana, já atendem às normas fundamentais do Programa PIF como a determinação dos componentes técnicos e econômicos da produção integrada constituindo um conjunto de informações que a fundamenta, tais como: realização da análise do impacto ambiental e de custo/benefício dos dois sistemas de produção e comparação dos resultados; promoção da formação de técnicos multiplicadores e executadores juntamente com a confecção de caderneta de campo para monitoramento do processo produtivo; produção de publicações técnicas para fundamentar os cursos de treinamento; formação de parcerias entre os produtores e ONGs para apoiar ações de regulamentação e de desenvolvimento de infra-estrutura que viabilize a implementação do programa PIF no país atendendo as exigências dos mercados consumidores e estabelecendo normas de produção; produção de frutas com níveis de resíduos abaixo do Limite Máximo; certificação da qualidade das frutas produzidas; definição de metodologias para determinação de níveis críticos para intervenções químicas para controle de pragas e doenças; levantamento dos agroquímicos permitidos pelos países importadores.

Pode-se conferir algumas normas gerais na Tabela 4. 
Tabela 4. Principais frutas do Sistema de Produção Integrada que já cumprem os objetivos PIF

\begin{tabular}{|c|c|c|c|c|c|c|c|}
\hline & & Maçã & Manga & Uva & Citrus & Pêssego & Banana \\
\hline Redução de Pesticidas & & $\begin{array}{l}10 \mathrm{a} \\
30 \%\end{array}$ & $30 \%$ & $\begin{array}{l}\text { Houve } \\
\text { redução }\end{array}$ & $\begin{array}{l}\text { Houve } \\
\text { redução }\end{array}$ & $10 \%$ & $\begin{array}{l}\text { Houve } \\
\text { redução }\end{array}$ \\
\hline \multirow{4}{*}{$\begin{array}{l}\text { Área Plantada com } \\
\text { Programa PIF (em ha). }\end{array}$} & 2000 & 3300 & 2512 & $*$ & - & 52 & - \\
\hline & 2001 & 6000 & 3014 & $*$ & 115 & 200 & 1666 \\
\hline & 2002 & 8000 & 3600 & $*$ & 1150 & 600 & 1666 \\
\hline & 2003 & 10000 & 4300 & $*$ & 12000 & 1200 & $*$ \\
\hline \multirow[t]{4}{*}{ Produção PIF (toneladas) } & 2000 & 132.000 & 67.824 & $*$ & - & 780 & - \\
\hline & 2001 & 240.000 & 81.300 & * & 2300 & 3000 & 58,33 \\
\hline & 2002 & 320.000 & 97.600 & * & 2300 & 9000 & 58,33 \\
\hline & 2003 & 400.000 & 117.120 & $*$ & 2400 & 18000 & $*$ \\
\hline $\begin{array}{l}\text { Confecção de caderneta de } \\
\text { campo para monitoramento }\end{array}$ & & + & + & + & + & + & + \\
\hline
\end{tabular}


Tabela 4. Principais frutas do Sistema de Produção Integrada que já cumprem os objetivos PIF

\begin{tabular}{|c|c|c|c|c|c|c|}
\hline & Maçã & Manga & Uva & Citrus & Pêssego & Banana \\
\hline $\begin{array}{l}\text { Metodologia para } \\
\text { determinar níveis críticos } \\
\text { para intervenção química } \\
\text { para o controle de pragas }\end{array}$ & + & + & + & + & $\begin{array}{l}+(\mathrm{a} \\
\text { partir } \\
\text { de } \\
2001)\end{array}$ & + \\
\hline $\begin{array}{l}\text { Levantamento de } \\
\text { agroquímicos utilizados e } \\
\text { monitoramento dos níveis } \\
\text { de resíduos }\end{array}$ & + & + & + & + & + & + \\
\hline $\begin{array}{l}\text { Capacitação de técnicos e } \\
\text { produtores }\end{array}$ & + & + & + & + & + & + \\
\hline $\begin{array}{l}\text { APPCC - Campo e ISSO } \\
14.000\end{array}$ & + & + & + & + & + & + \\
\hline $\begin{array}{l}\text { Agregação de valor à fruta } \\
\text { e aumento da } \\
\text { competitividade visando } \\
\text { atender exigências dos } \\
\text { mercados consumidores. }\end{array}$ & + & + & + & + & + & + \\
\hline $\begin{array}{l}\text { Análise da qualidade das } \\
\text { águas; análise dos solos } \\
\text { (metais pesados e } \\
\text { salinidade); geo- } \\
\text { referenciamento; }\end{array}$ & + & + & + & + & + & + \\
\hline
\end{tabular}

Fonte: Embrapa (2004a)

+ frutas que cumprem com os regulamentos do PIF

* dados não disponíveis

De modo mais amplo, as principais metas da PIF se resumem em caracterização dos recursos naturais e sócio-econômicos, monitoramento do uso de agrotóxicos e da ocorrência de pragas e seus agentes naturais e de controle. 
São implantados sistemas de produção com manejo do solo, nutrição de planta e controle de pragas e doenças em conformidade com técnicas que levem ao manejo da produção integrada, de modo que no futuro se possa ter uma fruticultura com produtos mais competitivos em termos de qualidade a nível nacional e internacional produzido de modo a preservar o ecossistema.

O arcabouço técnico operacional de suporte ao sistema é composto por Normas Técnicas Específicas (NTE), para todas as frutas (15 Áreas Temáticas), Grade de Agroquímicos, Cadernos de Campo e Pós-Colheita e Listas de Verificação - Campo e Empacotadora. A implantação do sistema de PIF no Brasil tem apresentado outros resultados de destaque como: i) aumento de emprego e renda na ordem de 3,0\% (PIF Maçã); ii) diminuição dos custos de produção na maçã (40,0\% em fertilizantes e 25,0\% em inseticidas) e, no mamão, em torno de 44,0\% da totalidade - campo e pós-colheita; iii) indicadores de redução em pulverizações; iv) diminuição de resíduos químicos nas frutas; e v) melhoria da qualidade do produto consumido, da saúde do trabalhador rural e do consumidor final (Embrapa, 2004).

Segundo Kossoski (2004), no Brasil as frutas das áreas que estiverem de acordo com o programa PIF, receberão um selo oficial que tem respaldo do MAPA e do Inmetro. Com esta conquista, acredita-se que aumenta o potencial de aceitação das frutas brasileiras no mercado internacional. O programa PIF facilita a colocação de produtos nacionais em mercados exigentes, como a França, em função do selo de qualidade Inmetro.

Segundo o mesmo autor, essa prática não é uma iniciativa da pesquisa, tendo-se constituído em resposta a uma exigência do mercado. Um dado relevante diz respeito à redução do uso de agroquímicos, nesse novo sistema produtivo. Em 1999, empregava-se 71,7 quilos de defensivo por hectare, sendo que ao final de 2002 esse volume tinha se reduzido a 3,4 quilos. Da mesma forma, no método da PIF pode ser constatada redução de $40 \%$ no custo de produção em relação aos pomares 
convencionais, com vantagem também para o sistema produtivo como um todo, Embrapa (2004c).

Tabela 5. Indicadores de redução de agroquímicos: resultados parciais em (\%)

\begin{tabular}{lllllll}
\hline & Maçã & Manga & Uva & Mamão & Caju* & Melão* \\
\hline Inseticidas & 25,0 & 43,3 & $53,0^{* *}$ & $30,0^{* *}$ & 25,0 & 20,0 \\
Fungicidas & 76,0 & 60,7 & 43,3 & 67,0 & 30,0 & 10,0 \\
Herbicidas & -- & 80,0 & 60,5 & 29,5 & - & - \\
Acaricidas & -- & -- & -- & $*$ & $*$ & 20,0 \\
\hline
\end{tabular}

Fonte: Embrapa (2004a)

*Previsão média 2003/2004

**Inseticida + Acaricida

Portanto, os produtores e empacotadoras de maçãs, uvas de mesa, mangas, mamão, caju e melão, que comprovarem ter experiências em Produção Integrada, de no mínimo um ciclo agrícola, poderão aderir ao sistema e serem avaliados por meio de Organismos de Avaliação da Conformidade (OAC) (instituições independentes de $3^{\mathrm{a}}$ parte), credenciados pelo Inmetro, a receberem um Selo de Conformidade da fruta, contendo a logomarca PIF Brasil e a chancela do MAPA e Inmetro.

O Acordo de Reconhecimento no Fórum Internacional de Acreditação (IAF) reconheceu e credenciou instituições dos mais diversos países do mundo para efetuar o credenciamento de Organismos na execução de tarefas relacionadas com a Avaliação da Conformidade e Certificação de Sistemas de Qualidade - no caso do Brasil é o Inmetro.

Os selos de Conformidade, contendo códigos numéricos, serão aderidos às embalagens das frutas, possibilitando a qualquer pessoa obter informações sobre: (i) procedência dos produtos; (ii) procedimentos técnicos operacionais adotados; e (iii) 
produtos utilizados no processo produtivo, dando transparência ao sistema e confiabilidade ao consumidor.

A execução de todo o sistema garante a rastreabilidade do produto, por meio do número identificador estampado no selo, que indica os registros obrigatórios das atividades de todas as fases envolvendo a produção e as condições em que foram produzidas, transportadas, processadas e embaladas. As frutas poderão ser identificadas desde a fonte de produção até o seu destino final, a comercialização.

Com a Produção Integrada de Frutas implantada e os Organismos de Avaliação da Conformidade em funcionamento, o Brasil está em condições de competitividade e igualdade para comercializar em qualquer mercado internacional e disponibilizar, no mercado interno, frutas de qualidade idênticas às exportadas, o que estimula iniciar, neste momento, a ampliação de articulações, estudos e implantação de outras espécies vegetais, tais como: olerícolas (batata, tomate e outras), flores, grãos (café, arroz), plantas medicinais, raízes e outras. No caso dos projetos de Produção Integrada de Morango e de Coco para o Estado do Espírito Santo, o governo local está patrocinando estes projetos por conta do erário estadual, via Secretaria de Estado da Agricultura, iniciativa pioneira neste caso. ${ }^{10}$

Pode-se dizer que o programa PIF é uma espécie de ferramenta disponibilizada ao setor produtivo com a intenção de manter os produtores de frutas nos mercados e possibilitar abertura a novas oportunidades com intuito de aumento de fatia de mercado.

A Tabela 6 apresenta um panorama da evolução da PIF na fruticultura brasileira. São indicadas na tabela: as frutas que já possuem o selo (logomarca) PIF Brasil, com as normas de cada fruta já elaboradas; as frutas cujas normas estão em processo de elaboração, mas que já se aderiram ao Programa PIF; e as frutas que estão se

\footnotetext{
${ }^{10}$ BUSCHINELLI, C.; MAGANHOTTO, C.M.; HERMES, L.C., op. cit., p.22.
} 
aderindo ao programa. Esse conjunto mostra que, desde 1998, os produtores vêm aderindo ao programa de modo voluntário, mostrando-se cada vez mais conscientes da necessidade da padronização e certificação da frutas brasileira, dada as exigências dos consumidores.

Tabela 6. Espécies de frutas priorizadas na PIF

\begin{tabular}{lcc}
\hline $\begin{array}{c}\text { Frutas que já } \\
\text { obtém o selo PIF }\end{array}$ & $\begin{array}{c}\text { Frutas que estão na } \\
\text { Produção Integrada, mas } \\
\text { que ainda estão no } \\
\text { processo de certificação. }\end{array}$ & $\begin{array}{c}\text { Frutas que estão na fase de } \\
\text { reeducação do produtor } \\
\text { para entrarem na produção } \\
\text { integrada }\end{array}$ \\
\hline Maçã & Coco & Caqui \\
Manga & Banana & Goiaba \\
Uva & Maracujá & Figo \\
Melão & & Abacaxi \\
Pêssego & & \\
Citrus & & \\
Mamão & & \\
Caju & & \\
\hline
\end{tabular}

Fonte: Andrigueto (2004)

Contudo, dentre os desafios para a sustentabilidade do programa PIF a fruticultura deve proporcionar: frutas de boa qualidade; preços acessíveis; cumprir normas de proteção ambiental; eliminação de agrotóxicos (extremamente tóxicos); diminuição das quantidades de pulverizações/ano; menor uso de herbicidas e acaricidas; diminuição da pressão seletiva sobre predadores das pragas; diminuição dos riscos de contaminação do solo, água, fruto e próprio homem; aumento da profissionalização dos produtores; racionalização das práticas e do uso de energia; maior eficiência das plantas e sustentabilidade do sistema de produção. 
Com tais vantagens a Tabela 7 mostra que muitos produtores no Brasil já se conscientizaram e aderiram ao PIF, aumentando cada vez mais a produção de frutas com a marca PIF Brasil e a área plantada de modo ecologicamente correto.

Tabela 7. Quantificação dos dados das frutas aderidas ao Programa PIF

\begin{tabular}{|c|c|c|c|}
\hline Espécie & $\begin{array}{ll}\text { Número } & \text { de } \\
\text { produtores } & \end{array}$ & Área (ha) & Produção $(\mathrm{t})$ \\
\hline Maçã & 211 & 13.196 & 461.186 \\
\hline Manga & 187 & 7.025 & 172.221 \\
\hline Uva & 104 & 3.042 & 91.263 \\
\hline Mamão & 18 & 1.200 & 120.000 \\
\hline Citrus & 95 & 2.038 & 37.065 \\
\hline Banana & 119 & 2.678 & 77.729 \\
\hline Pêssego & 105 & 520 & 6.240 \\
\hline Caju & 15 & 1.500 & 1.800 \\
\hline Melão & 30 & 3.560 & 96.176 \\
\hline Goiaba & 27 & 75 & 300 \\
\hline Figo & 25 & 120 & 1.093 \\
\hline Caqui & 23 & 84 & 3.000 \\
\hline Maracujá & 30 & 56 & 5.500 \\
\hline Coco & 12 & 414 & 20.368 \\
\hline Abacaxi & - & - & - \\
\hline Total & 1001 & 35.508 & 1.094 .615 \\
\hline
\end{tabular}

Fonte: Andrigueto (2004)

No Brasil, a PIF procura incorporar técnicas compatíveis com o agroecosistema; atenta à saúde dos trabalhadores e consumidores; frutas de qualidade; rentabilidade; preços diferenciados dos produtos. Além da convicção do produtor, no 
entanto, é preciso dispor de formas para convencer também o consumidor das vantagens que o consumo desses produtos representa para a sua saúde, bem como a importância do respeito ao meio ambiente.

No mercado internacional, atualmente, frutas advindas do PIF possuem preferência na comercialização, em relação ao sistema convencional. A partir desta preocupação o Brasil desenvolveu um sistema de Avaliação de Conformidade ${ }^{11}$ que fosse compatível com exigências internas e principalmente externas. O modelo de Avaliação de Conformidade do Programa PIF indicado no Anexo B, desenvolvido junto ao MAPA e CNPq, tendo como objetivo geral a elaboração de um modelo conceitual, estratégico e operacional dos sistemas de Avaliação de Conformidade e do Cadastro Nacional de Produtores e Empacotadoras sob o regime da PIF (Andrigueto, 2004).

A Certificação de Qualidade no Campo (no caso do Brasil) poderá ser efetivada por meio da utilização de normas ou protocolos. O "Protocolo Europeu de Boas Práticas Agrícolas" (no Brasil utiliza-se o EUREPGAP) associado ao ISO 9001 (BRC Qualidade do Produto), trata da normalização das práticas agrícolas de produção e certificação do produto final. $\mathrm{O}$ protocolo reconhece as ações mais fomentadas e implantadas por produtores e implementa o sistema de boas práticas agrícolas na agricultura, atendendo à minimização de impactos ambientais adversos.

O conhecimento das Boas Práticas, com base no uso das Normas sugeridas pelo EUREPGAP+BRC (ISO 14001), servirá a profissionais da área de agronomia e afins envolvidos diretamente no Programa de Produção Integrada de Frutas brasileira, uma vez que EUREPGAP é um passo anterior à certificação da PIF. Espera-se com isso que o processo de certificação de qualidade do campo e da produção integrada das frutas

\footnotetext{
${ }^{11}$ O Sistema "Modelo de Avaliação da Conformidade da Produção Integrada de Frutas" (exposto no anexo B) foi lançado em $01^{\circ}$ de agosto de 2002 e oficializado pelo Ministro do MAPA, em 11 de setembro de 2002, em conjunto com a Logomarca PIF Brasil, Produção Integrada de Maçã (PIM) e o Selo de Conformidade da Maçã. A PIF em 2003 apresentou resultados significativos em relação ao número de adoções de produtores, área em PIF e montante da produção (Andrigueto, 2004).
} 
destinadas a exportação seja agilizado, principalmente aqueles em curso nas Unidades de Produção contempladas pela Embrapa ${ }^{12}$.(Pessoa e Silva, 2004; Embrapa, 2004).

O MAPA, através do Programa PIF, auxilia os produtores com recursos financeiros e provê suporte técnico através de especialistas da Embrapa. Esses agrônomos, em parceria com o Serviço Brasileiro de Apoio a Micro e Pequenas Empresas (SEBRAE) e a Companhia de Desenvolvimento dos Vales do São Francisco e do Parnaíba (CODEVASF), mantêm uma equipe técnica agrícola que promove a transferência da tecnologia para o programa PIF, visando particularmente a exportação de frutas. Em Petrolina, por exemplo, já existe em torno de 150 a 200 produtores de uva e manga que recebem essa assistência técnica, gratuitamente do governo, para que sua fruta receba a logomarca PIF $^{13}$.

Para que o produtor consiga a logomarca PIF respaldada pelo MAPA, tem que atender aos seguintes procedimentos: primeiramente, este tem que ter conhecimento do Marco Legal (que está no Inmetro ou Embrapa) e obter uma adesão junto MAPA e Inmetro fazendo um período de quarentena para os seus produtos. Essa etapa é uma espécie de ciclo de cultura, onde o produtor tem que fazer uso das Boas Práticas Agrícolas do Marco Legal constituído de quinze espécies temáticas, desde práticas culturais, fertilizantes até o meio ambiente.

Uma vez concluído esse ciclo de cultura, o produtor contrata uma certificadora (dispêndio do produtor), que mandará um auditor para verificar se as exigências foram integralmente atendidas, de acordo com as normas do Marco Legal (basta a identificação de um item que não esteja em ordem, para impedir que o produtor receba a certificação) para depois de toda a inspeção o auditor recomendar a certificação.

\footnotetext{
${ }^{12}$ BUSCHINELLI, C. (Embrapa Meio Ambiente, Jaguariúna). Comunicação pessoal, 2004.

${ }^{13}$ BUSCHINELLI, C.; MAGANHOTTO, C.M.; HERMES, L.C., op. cit., p. 22.
} 
Para que o selo tenha valia tanto no mercado nacional, como internacional, a certificadora contratada tem que ser autorizada pelo Inmetro. Ou seja, esta tem que ser acreditada (o que significa que passou pelo Processo de acreditação PIF, EUREPGAP, ISO 14001). Esta certificadora dará uma declaração de que o produtor segue as normas da Produção Integrada descritas no Marco Legal respaldado pelo MAPA.

A partir desse momento as frutas que vão para as empacotadoras ("packing house") serão acreditadas e receberão o selo PIF, para então sua embalagem sair da empacotadora com a logomarca $\mathrm{PIF}^{14}$.

Para que todo este processo seja realizado, o produtor precisa de informações sobre as normas internacionais, os protocolos internacionais vigentes para frutas como exemplo o EUREPGAP, conhecer os organismos internacionais importantes para a comercialização de frutas, saber a importância da normatização no comércio internacional, como mostrado a seguir, além de procedimentos ou requisitos fundamentais na comercialização de frutas como: Ensaio, Certificação, Avaliação de Conformidade, Regulamentação Técnica, Normas, Acreditação, que se encontram num glossário no Anexo C.

\subsection{Protocolo europeu de boas práticas agrícolas (EUREPGAP)}

O EUREPGAP teve início em 1997, por varejistas do Euro-Retailer Produce Working Group (EUREP) ${ }^{15}$. Vem se desenvolvendo através de uma parceira entre produtores e consumidores "varejistas". O objetivo é desenvolver padrões e procedimentos da certificação global do Good Agricultural Practices (GAP), (EUREPGAP, 2004).

\footnotetext{
${ }^{14}$ FARIA, A.C. (Bureau Veritas Quality International - BVQI, Belo Horizonte). Comunicação pessoal, 2005.

15 Este protocolo foi elaborado no âmbito de um grupo de trabalho, coordenado pelo EUREP, representativo de todos os estágios envolvidos no processo de produção e comercialização de frutas e vegetais na Europa. Foi resultante de vários encontros realizados em 1999 e em 2000, onde mais de 600 pessoas de mais de 25 países do mundo participaram de ambos.
} 
Tecnicamente, o EUREPGAP visa ser reconhecido pelos critérios de certificação internacional como o "ISO 65". Representantes de todo o mundo e de todas as cadeias alimentícias estão envolvidos no desenvolvimento destes documentos. Agregando a visão dos industriais, dos consumidores e das organizações ambientais e governamentais para a formação dos Protocolos. A opinião de todos estes elos das cadeias produtivas tem produzido um notável protocolo que fazendeiros do mundo todo podem operar em conformidade com o GAP (EUREPGAP, 2004).

A versão mais recente deste protocolo, publicada em março/2001, define elementos essenciais para o desenvolvimento de boas práticas para a produção global de produtos hortifrutícolas. Essas diretrizes definem o padrão mínimo aceitável para conduzir grupos de produtores Europeus, que apresentam um mínimo dos requisitos exigidos pelo Protocolo. Esse não estabelece métodos a serem utilizados para as ações obrigatórias nem para as ações recomendadas, porém reconhece as ações mais fomentadas e implantadas por produtores, grupos de produtores e organizações de produtores, em esquemas local e nacional, em desenvolvimento e implementando o sistema de boas práticas agrícolas na agricultura. Esse sistema, por sua vez, atende à minimização de impactos ambientais adversos (Silva et al., 2004).

O "GAP" incorpora práticas do Manejo Integrado de Pragas (MIP) e o Manejo Integrado da Cultura (MIC), essenciais segundo os membros do EUREP, para a melhoria contínua e produção agrícola sustentável.

O protocolo também encoraja o uso do Hazard Analysis and Critical Control Points (HACCP $)^{16}$, estabelecendo diretrizes para: armazenamento de registros, variedades e porta-enxertos, histórico do local e gerenciamento local, Manejo de solo e substrato, Uso de fertilizantes, Irrigação, Proteção da Cultura, Colheita, Tratamentos Pós-Colheita, Manejo de lixo e poluição, reciclagem e reuso, Saúde dos trabalhadores, segurança e bem-estar, temas ambientais e formulário de acompanhamento.

\footnotetext{
${ }^{16}$ No Brasil foi traduzido como: Análise de Perigos e Pontos Críticos de Controle (APPCC).
} 
Para a obtenção de certificação EUREPGAP é realizada uma verificação de quanto uma operação e/ou um local, isto é, uma fazenda ou propriedade, está de acordo com todos os pontos de controle estabelecidos em um "checklist". O resultado da inspeção é um resumo instantâneo (tipo cumpre ou não cumpre), não uma avaliação de um sistema de manejo de qualidade (QMS) e nem a operação de um QMS sob um período de tempo (Exemplo: um inspetor vai a fazenda e preenche um "checklist" do EUREPGAP. O relatório do inspetor será assinado por ele e pelo fazendeiro ou pessoa responsável pela operação). As regras que conduzem as inspeções estão de acordo com a norma Européia EN45004 (Silva et al., 2004; Checkplant, 2004).

Organizações de produtores podem solicitar um reconhecimento de equivalência com os padrões EUREPGAP e, por meio disso, facilitar o comércio global e a harmonização dos critérios técnicos (EUREPGAP, 2004). Sendo este um fato muito importante para o Brasil no caso da PIF.

O objetivo principal do EUREPGAP é tranqüilizar os consumidores. Depois de problemas com alimentos pouco seguros, como se observou no caso da "vaca louca", questões importantes como pesticidas e a rápida introdução de produtos geneticamente modificados, fizeram com que os consumidores mundiais passassem a se interessar e questionar a forma adotada para a produção do alimento.

Com a adoção de boas práticas agrícolas, acredita-se que irá reduzir os riscos da produção agrícola, onde o EUREPGAP fornece as ferramentas para, que possa, objetivamente, verificar as melhores práticas agrícolas através de certificações relevantes para alimentos embalados e processados, num sistemático e consistente caminho em todas as partes do mundo (Chaim, 2004).

Outro ponto é providenciar um fórum para melhoramentos contínuos. Os comitês técnicos e de padrões, composto por produtores e varejistas, têm um programa formal de trabalho para revisar questões de emergências e riscos de tributo/quota. Este é um processo rigoroso, seguindo os princípios do HACCP, e envolve especialistas para revisar as versões do protocolo (EUREPGAP, 2004). 
O sistema EUREPGAP fornece ferramentas, através dos protocolos e os critérios de preocupação com as práticas nas unidades produtoras (uma vez que os produtos estejam de acordo com o controle de outros códigos de conduta e certificações relevantes para alimentos embalados e processados).

Tais protocolos definem um conjunto de regras de Boas Práticas Agrícolas (GAP) para a produção de frutas e legumes, promovendo: a adoção de técnicas de produção integrada; a redução do uso de agroquímicos; a implementação de um sistema fidedigno de rastreabilidade dos produtos agrícolas, desde o produtor ao consumidor; o estabelecimento de um único protocolo, reconhecido por todos e submetido a uma certificação independente; a comunicação com os consumidores e principais parceiros, incluindo agricultores, exportadores e importadores (EUREPGAP, 2004).

Para obter a certificação de conformidade, no EUREPGAP ${ }^{17}$, o produtor deve implantar todos os requisitos previstos nas normas:

a) Cumprir os requisitos legais nacionais e internacionais aplicáveis às suas atividades;

b) Estabelecer uma Gestão Ambiental que garanta a minimização dos seus impactos ambientais, incluindo o aproveitamento racional dos recursos naturais;

c) Garantir o uso e o manuseio adequado de defensivos agrícolas;

d) Estabelecer uma Gestão Ocupacional que vise a redução e controle dos perigos e riscos aos quais os trabalhadores rurais estão sujeitos;

e) Estabelecer uma Gestão de Qualidade do processo produtivo, de forma a garantir a segurança dos alimentos produzidos;

${ }^{17}$ EUREPAGAP. Fruits and vegetables. http://www.eurep.org (20 Nov. 2004) 


\subsection{Organismos internacionais importantes para a comercialização de frutas}

\subsubsection{Codex Alimentarius}

A Comissão do Codex Alimentarius (único organismo competente para elaboração das normas, códigos de práticas, diretrizes e recomendações), foi criada em 1962 por decisão da FAO e da OMS. Significando "Código de Alimentos", o Codex se tornou uma referência essencial para os envolvidos da área de alimentos e que buscam a inocuidade e a melhora da qualidade dos alimentos. O principal objetivo dessa Comissão é tornar eqüitativo o comércio de alimentos e, obviamente, a saúde dos consumidores, sendo a produção agropecuária um dos setores de grande importância na padronização para exportação de muitos países em desenvolvimento (Codex, 2004).

Tal ferramenta é relevante para o crescimento do comércio mundial, criando possibilidades para a expansão da produtividade econômica, implicando em crescimento do comércio entre países, o que pode também significar uma maior probabilidade de transmissão de doenças (entre países). Isso leva à geração de normas adequadas para a proteção da saúde da população.

Essas normas são adotadas visando eliminar conflitos, via harmonização, de maneira que possam, em última instância, eliminar o uso de regulamentos técnicos como barreiras.

Em relação à $\mathrm{OMC}$, as normas Codex foram estabelecidas como referência no âmbito do Acordo sobre a Aplicação de Medidas Sanitárias e Fitossanitárias, onde estas normas são reconhecidas como padrão de referência que atende requisitos do Acordo como não discriminação, elaboração de exigências fundamentadas com base científica, restringindo a utilização de barreiras não justificadas (cientificamente) ao comércio (FAO, 2004).

Assim sendo, o Codex passa a ser ponto de referência aos consumidores, produtores e processadores de alimentos e agências nacionais de controle de alimentos e 
comércio internacional. A Comissão Codex atua e se caracteriza como um órgão internacionalmente reconhecido.

O Codex é uma comissão intergovernamental cujo objetivo é o desenvolvimento de normas a serem adotadas internacionalmente. Resulta de uma coordenação com todas as organizações internacionais governamentais e não governamentais que atuam na área de alimentos e que buscam ter como base de apoio centros de excelência (Codex, 2004). Atualmente o Codex é composto por 169 membros e participação de observadores como representantes das industrias e de organizações de consumidores.

No Brasil, as atividades do Comitê Codex Alimentarius do Brasil (CCAB) são coordenadas pelo Inmetro. Este comitê possui como membros órgãos do governo, indústrias, entidades de classe e órgãos de defesa do consumidor (INMETRO, 2004).

A necessidade de cooperação do governo para a elaboração e aperfeiçoamento das normas relativas aos alimentos para o consumo humano é reconhecida. Também se reconhece a necessidade da formulação e adoção de normas internacionais similares a fim de facilitar e proteger o intercâmbio dos produtos entre os países (Codex, 2004).

Durante os últimos anos, a indústria de alimentos do mundo inteiro foi diretamente afetada por um grande aumento de legislações e regulamentos. A partir disso, desenvolveu-se no Codex Alimentarius da Organização Mundial de Saúde (OMS), o HACCP, que tem sido cada vez mais usado na indústria de alimentos no mundo exigindo que um sistema de segurança de alimentos efetivo seja estabelecido através da aplicação de uma abordagem sistemática às analises de perigo e risco (FAO, 2004).

Cada vez mais, empresas que fazem parte da Cadeia de Fornecimento de alimentos devem ser capazes de demonstrar que possuem um sistema HACCP eficaz, de acordo com as variantes de requisitos internacionais, nacionais e locais. Atender aos 
regulamentos locais de higiene para alimentos e a aplicação de técnicas de análise de risco auxilia aqueles que fazem parte da Cadeia de Fornecimento de alimentos a enfrentar processos complexos. Através do HACCP é possível adotar uma abordagem normalizada para garantir a segurança dos alimentos, ajudando a empresa a demonstrar seu compromisso no cumprimento das exigências da legislação e dos clientes, podendo dar maior sustentação a uma defesa caso alguma diligência seja recebida pela empresa (Codex, 2004).

\subsubsection{HACCP: análise de perigos e pontos críticos de controle (APPCC) sua importância no Brasil e no mundo}

Dentro do escopo das normas, diretrizes e recomendações do Codex Alimentarius consta o "Código de Práticas Internacionais Recomendadas em Princípios Gerais de Higiene Alimentar". Este código é reconhecido mundialmente como essencial para garantir a inocuidade e a segurança dos alimentos, sendo recomendado aos governos, indústria e consumidores. Como resultado da citação da Comissão do Codex Alimentarius nos Acordos Internacionais de Barreiras Técnicas (TBT), Sanitárias e Fitossanitárias (SPS), devidamente explicados logo a seguir, o HACCP passou a ser referência para as exigências internacionais de inocuidade alimentar.

Segundo Fermam (2003), o sistema HACCP, que possui fundamentação científica, consiste em etapas seqüenciais para identificar, avaliar e controlar perigos de contaminação de alimentos, da produção até o consumidor. Seus objetivos são prevenir, reduzir ou minimizar os perigos associados ao consumo de alimentos, estabelecendo deste modo os processos de controle para garantir um produto inofensivo. Tem como base a identificação dos perigos potenciais para a inocuidade do alimento e as medidas preventivas para controlar as situações que criam os perigos.

É crescente a aceitação do Sistema HACCP em todo o mundo, por indústrias, governos e consumidores. O conceito de HACCP aplica-se a todos os 
estágios da cadeia de produção do alimento, desde o plantio, cultivo, colheita, processamento, criação animal, fabricação, distribuição e comercialização, até o seu preparo para consumo. Recomenda-se a adoção, a mais completa possível, do HACCP por toda a cadeia alimentar para garantir-se a obtenção de um produto inofensivo ao consumidor.

Embora sejam incontestáveis os benefícios oriundos de sua adoção, o sistema HACCP deve atender, obrigatoriamente, aos requisitos constantes dos Acordos TBT e SPS, para que possa ser reconhecido como válido pela comunidade internacional. Assim, o HACCP é analisado sob a coordenação destes Acordos, com a finalidade de determinar se a sua adoção, por parte dos países-membro da OMC, constituir-se-á ou não, em um obstáculo desnecessário ao comércio. Tal fato torna relevante o conhecimento e a informação pelos países exportadores sobre as medidas que vêm sendo exigidas nos países importadores.

Portanto, o setor da indústria de alimentos nacional, que vinha redirecionando seus sistemas de gestão de qualidade desde a década de 80 no intuito de utilizar um sistema reconhecido internacionalmente, foi pioneiro ao adotar a partir de 1991 o Sistema APPCC adotado mundialmente, compatível com a série ISO 9000 e o sistema de "Qualidade Total”, por garantir confiabilidade e transparência ao processo de controle, segurança alimentar, qualidade aos produtos alimentícios, redução de custos e aumento de lucratividade (Pessoa e Silva, 2004).

Segundo o MAPA, entende-se por "Perigo": "causas potenciais de danos inaceitáveis, que possam tornar um alimento impróprio ao consumo e afetar a saúde do consumidor, ocasionar a perda da qualidade e da integridade econômica dos produtos. Genericamente o perigo é a presença inaceitável de contaminantes biológicos, químicos ou físicos na matéria prima ou nos produtos semi-acabados ou acabados e não conformidade com o Padrão de Identidade e Qualidade (PIQ) ou Regulamento Técnico estabelecido para cada produto" (Brasil, 2004a). 
Para prevenir riscos e, portanto, gerar produto de qualidade, além de conhecimento dos fatores que ocasionam perigos e seus pontos mais críticos, existe a necessidade de investir em conhecimento, prevenção e controle dos produtos agropecuários nacionais.

A APPCC está associada às Boas Práticas de Fabricação (BPF) e estabelece programas de boas práticas ligadas à fabricação (indústria) estabelecendo diretrizes para minimizar perigos, monitorar, estabelecer ações corretivas e emergenciais, procedimentos de verificação e de registros.

A qualidade de produto, segundo a APPCC, está baseada no conhecimento de elementos de microbiologia, perigos químicos e físicos que podem ocorrer, exigências do Codex Alimentarius para as boas práticas de fabricação, aspectos de higiene pessoal e comportamento no trabalho; procedimentos de limpeza e sanificação de superfícies, controle de pragas problemáticas para a indústria de alimentos; qualidade da água utilizada para abastecimento e limpeza; seleção de fornecedores com qualidade assegurada; controle metrológico visando medições confiáveis; planos de amostragem para análise microbiológica; e controle estatístico de processo $^{18}$ (Silva, 2004).

O programa PIF no Brasil segue todas as normas do Codex Alimentarius para Limite Máximo de Resíduos (LMR) na produção de frutas e os produtores que estão aderidos ao programa PIF todos possuem o sistema APPCC ${ }^{19}$.

${ }^{18}$ Determinação de limites críticos a serem empregados no monitoramento dos Pontos Críticos de Controle - PCC. A responsabilidade de implantação do Sistema APPCC cabe ao Serviço de Inspeção do Pescado e Derivados (SEPES), do Departamento de Inspeção de Produtos de Origem Animal.

${ }^{19}$ BUSCHINELLI, C.; MAGANHOTTO, C.M.; HERMES, L.C., op. cit., p.22. 
Como Boas Práticas Agropecuárias no contexto da APPCC segmento campo, foram levantadas as atividades no contexto da Produção Integrada de Manga e Uva realizadas pelas Embrapa Meio Ambiente, Embrapa Semi-Árido e Valexport no Sub-Médio São Francisco, que conta com o KIT-APPCC frutas, as atividades de fruticultura irrigada (abacaxi, banana, caju, coco, limão, melancia, manga, cajá e bacuri) realizadas pela Embrapa Meio Norte, as pesquisas da EMDAGRO da Secretaria de Estado da Agricultura, do Abastecimento e da Irrigação de Sergipe para acerola, citros, banana, mamão, mangaba, caju anão precoce e coqueiro anão; da Estação Experimental de Citricultura de Bebedouro (Bebedouro/SP), voltadas para citricultura e produção integrada de citros; da Embrapa Semi-Árido para programas de manejo integrado de pragas de banana, uvas sem sementes, manga, pupunha e coco, da Embrapa Tabuleiros Costeiros para a produção de coco; da Embrapa Hortaliças relacionadas às Boas Práticas de Produção de Hortaliças e aplicação dos conceitos de APPCC na produção; da Embrapa Uva e Vinho relacionada à Produção Integrada de Maçã; da Embrapa Agroindústria Tropical relacionada à aplicação do sistema APPCC na Produção de polpa congelada, entre outros de frutas frescas e hortaliças; da GEDAGRO voltados para a qualidade total rural e para a capacitação rural voltados para leite, derivados de cana-deaçúcar, frutas e hortaliças, café, etc.; da Embrapa Gado de Leite, relacionados a produção, armazenamento e transporte de leite cru; do SENAR voltados para a formação do profissional rural, promoção social e educação a distância, entre outros ${ }^{20}$ (Pessoa e Silva, 2004).

\subsubsection{Animal and Plant Health Inspection Service (APHIS)}

O Serviço de Inspeção para saúde animal e da planta é responsável por proteger e promover a segurança agrícola dos Estados Unidos. A APHIS é uma parte integral do departamento de agricultura (USDA) que tenta prevenir a nação com a segurança dos alimentos disponíveis, como por exemplo, a mosca da fruta mediterrânea, pestes agrícolas entre outros (APHIS, 2004).

${ }^{20}$ BUSCHINELLI, C.; MAGANHOTTO, C.M.; HERMES, L.C., op. cit. p. 22. 
O Serviço de Inspeção da Saúde Animal e planta, no United States Departament of Agriculture (USDA), dos EUA, é uma ação da agencia que trabalha com outras agencias Federais, Congresso e Estados, interessados em agricultura. (publico em geral). Para proteger a saúde e valores da agricultura Americana e seus recursos naturais (Dehaven, 2004).

O APHIS usa vários métodos de proteção que assegurem seus consumidores guardando-os contra a introdução de doenças e pestes de plantas e animais que poderia limitar a produção ou arriscar trazendo perigos para o mercado exportador. Ao mesmo tempo o APHIS monitora e responde pelas ações potenciais de bioterrorismo na agricultura, espécies de doenças entre plantas, humanos, animais domésticos e selvagens. Também se destina às barreiras sanitária e fitossanitárias ao comércio, com o objetivo de resguardar tratamento humano e animal. Finalmente esta também assegura a biotecnologia derivada de produtos agrícolas assegurando a segurança do meio ambiente (APHIS, 2004).

No sistema de proteção, sua missão é fazer de modo cuidadoso a provisão de leis federais especifica. Muitas ações recentes estão incluindo Proteção da Planta em 2000; Proteção da saúde animal, em 2002 e proteção as saúde e segurança por conta do bioterrorismo em 2002 (APHIS, 2004).

O sistema é baseado na estratégia de salvaguardar a saúde humana, de animais e plantas, fazendo um ecossistema seguro, possibilitando um comércio agrícola seguro, e reduzindo as perdas de recursos agrícolas e naturais. Os principais objetivos da APHIS são:

1) Assegurar a segurança e saúda de animais e plantas e ecossistemas nos Estados Unidos;

2) Facilitar a segurança do comércio agrícola; 
3) Assegurar a $\backslash$ efetividade e eficiência do gerenciamento de programas para alcançar a missão do APHIS;

Segundo Dehaven (2004), a Globalização, o livre acordo de comércio, o transporte ou troca de tecnologias tem aumento o risco para a introdução de espécies exóticas e nocivas á saúde humana e agrícola, aumentando as doenças e pestes de plantas e animais. O APHIS assegura o rigor científico avaliando o potencial tratamento para a saúde, e ao mesmo tempo tentando não impedir o comércio. O APHIS também desenvolve regulamentos para a importação de produtos agrícolas e juntamente tentando assegurar a agricultura norte americana, deixando sem obstáculos para restrições sanitárias e fitossanitárias do comércio entre seus parceiros. Sendo visto como um líder internacional onde padrões SPS são desenvolvidos e aplicados e onde são prioridades capacitando com respaldo científico a construção dos resultados.

As prioridades do APHIS entre os anos de 2003-2008 são:

1) Assegurar a pesquisa segura e biotecnologia agrícola;

2) Coordenação nacional de pestes e doenças e fiscalização e detecção dos sistemas;

3) Sistemas de saúde responsável por animal e plantas;

4) Resolver o problema de barreiras ao comércio relatando regras sanitárias e fitossanitárias (SPS);

5) Desenvolver alianças e posições de políticas norte americanas. Redução de tratamento domésticos aumentando diretamente a proteção da regulamentação fiscal, avaliando a redução do risco das atividades;

6) Gerenciamento de regras e objetivos relatados para recursos da saúde de animais e plantas (norte americanos) e conflitos agrícolas. 
Resumindo o objetivo futuro do APHIS é o mesmo do passado, ou seja, a proteção das fronteiras norte-americanas, assegurando a saúde da agricultura americana. (APHIS, 2004). Pode-se verificar um modelo de normas APHIS direcionadas ao Brasil no Anexo D.

\subsubsection{Food and Drugs Administration (FDA)}

O FDA é responsável pela proteção da saúde pública assegurando a saúde, eficácia e segurança de remédios humanos e veterinários, produtos biológicos, equipamentos, planos e artifícios médicos, nossa oferta de alimentos, cosméticos e produtos que emitam radiação.

O FDA também é responsável por avançar a saúde publica pelo auxilio da rapidez das inovações feitas pela medicina e para os alimentos mais efetivamente. Auxiliando o público com embasamento científico e informação que necessitem para melhorar a segurança de alimentos e remédios.

\subsection{Discussões sobre os acordos internacionais relevantes para a comercialização de frutas}

Desde a criação da OMC, em 1995, as regras que regem o comércio entre os países têm se tornado mais rígidas. Estas regras são o objetivo de Acordos Internacionais, que são assinados pelos países quando sua adesão a OMC. Entre estes acordos, figuram o Acordo de Barreiras Técnicas ao comércio (TBT) e o Acordo de Barreiras Sanitárias e Fitossanitárias (SPS).

Barreiras técnicas (TBT) e Medidas Sanitárias e Fitossanitárias (MSPS) são crescentemente importantes no comércio de produtos agrícolas, sendo implementadas 
para garantir que o alimento seja seguro para o consumidor, prevenindo ao mesmo tempo a expansão de doenças e pestes entre animais e plantas.

É crescente a preocupação do consumidor, principalmente em países desenvolvidos, com a qualidade dos alimentos e conseqüente redução dos riscos. A partir disso, segurança alimentar e segurança do alimento passou a ser um assunto importante no ranking dos países desenvolvidos (Jensen, 2001). Tal tema tem sido utilizado nas negociações como uma das justificativas da manutenção do protecionismo e de subsídios à produção e às exportações. A sensibilidade do tema é justificada, havendo consenso sobre sua importância entre todos os membros da Organização Mundial do Comércio.

È importante ressaltar uma diferença existente na tradução de segurança alimentar. Segundo Kassouf e Spers (1996), segurança alimentar no sentido "food security" pode ser visto do ponto de vista quantitativo, a qual é obtido através do aumento da renda familiar, conjuntamente com uma oferta adequada de alimentos via aumento da produção interna ou aumento da importação de alimentos. Outro sentido, segundo os mesmo autores, de segurança alimentar é "food safety", que tem crescido em importância juntamente com os novos processos de industrialização e com as novas tendências de comportamento do consumidor, sendo entendido do ponto de vista qualitativo, ou seja, a garantia do consumidor em adquirir um alimento com atributos de qualidade, entre os quais destacam-se os atributos ligados à saúde.

A segurança alimentar do ponto de vista qualitativo, pode ser entendida como aquisição, pelo consumidor, de alimentos de boa qualidade, livres de contaminantes de natureza química como pesticidas, fungicidas, acaricidas, ou qualquer outra substância que possa acarretar problemas à saúde (Kassouf e Spers, 1996).

O presente trabalho trata da segurança das frutas para o consumidor, ou seja, de uma garantia que o consumidor possa ter quando adquirir determinada fruta. Que esta esteja certificada como um alimento saudável para ele, estando livre de agrotóxicos, de contaminantes biológicos como organismos patogênicos, isenta de problemas físicos 
(como vidros, pedras, ou queimaduras e rachaduras provocadas por tempo de maturação). $\mathrm{O}$ alimento quando passa por um processo de certificação e recebe um selo de garantia dá ao consumidor mais tranqüilidade quanto a sua segurança, garantindo-lhe que está seja saudável e é inócua à sua saúde.

Através do presente trabalho procurar-se-á mostrar a preocupação dos produtores de frutas brasileiras com esse tema; a sua procura de informação e adequação às novas exigências do mercado interno e externo e adesão ao Programa PIF (do Brasil) que dará ao seu produto um "selo" de garantia da inocuidade da fruta.

Além disso, organismos como Embrapa, Ministério da Agricultura, CNPq, entre outros (como organismos não governamentais), têm se preocupado com as discussões existentes nas negociações internacionais tentando colocar o comércio brasileiro de alimentos, neste caso, com um foco em frutas, a par do que acontece com os Acordos internacionais (TBT e SPS), com as discussões levadas à OMC e com as possíveis tendências para as quais o mercado de alimentos pode se direcionar num futuro próximo, pois o Brasil terá que estar preparado e organizado, para atender o mercado.

Segundo o Ministério da Agricultura (Brasil, 2004b), a questão da segurança alimentar pode ser vista, de maneira geral, através de duas óticas: i) da disponibilidade física de alimentos que atendam em termos de quantidade, preço e qualidade as necessidades das populações; e, ii) do acesso econômico e físico de determinadas populações e países a esta oferta. Pode-se ainda afirmar que essas óticas se refletem em problemas distintos para diferentes países, sendo que a primeira preocupa primordialmente os países desenvolvidos enquanto que a segunda, em particular o acesso do ponto de vista econômico, os países em desenvolvimento e de menor desenvolvimento relativo. Para alguns países desenvolvidos existe ainda a preocupação de garantia de acesso físico aos alimentos como componente essencial de sua segurança alimentar.

Assim, a questão da segurança alimentar (alimento seguro para o consumo) se apresenta de forma distinta para os países desenvolvidos e em desenvolvimento, não 
sendo possível dispor de uma proposta única para os diferentes problemas de segurança alimentar com a qual os membros se defrontam. Há uma contradição fundamental quando alguns membros buscam apoio à medida que distorce a produção e o comércio entre os países em desenvolvimento e os países de menor desenvolvimento relativo, onde o problema da segurança alimentar é mais sério e real. Essas propostas, tendo como justificativa a busca da segurança alimentar, são na verdade inconsistentes com os objetivos de uma efetiva garantia de segurança alimentar, em particular para aqueles membros da OMC que são afetadas de forma dramática pelo problema.

No entanto, medidas TBT e principalmente SPS podem ser usadas como artifício de protecionismo para manter competidores estrangeiros fora do comércio. $\mathrm{O}$ Acordo SPS da OMC foi criado para diferenciar estas duas funções de medidas. Segundo Jensen (2001), do ponto de vista dos países em desenvolvimento, acredita-se que estes têm a maior demanda para um acordo efetivo desse gênero, mas na prática, o que acontece é que há grandes dificuldades quando estes usam o Acordo. Poucos países de renda média aparecem com benefícios claros em relação ao Acordo SPS e a maioria dos países em desenvolvimento não possue recursos financeiros, humanos e técnicos necessários para tal compromisso. Especialmente países menos desenvolvidos, estes são excessivamente sobrecarregados pelos custos de implementação do Acordo SPS.

No Acordo, consta o reconhecimento do direito que cada país possui em adotar normas que considerem apropriadas, por exemplo, para a proteção da saúde e da vida de pessoas e dos animais ou a preservação dos vegetais, para a proteção do meio ambiente ou em defesa de outros interesses dos consumidores. Estes são, segundo o Acordo, objetivos legítimos (TBT 2.2) para a adoção de medidas restritivas. Deve-se, contudo, levar em consideração os seguintes elementos: a informação técnica e científica disponível, a tecnologia de processamento conexa ou os usos finais a que se destinam os produtos, entre outros (Fermam, 2004).

Medidas SPS e TBT têm aumentado de maneira relevante em países desenvolvidos, porque nas Rodadas Internacionais, Negociações Multilaterais e até 
mesmo Bilaterais, as barreiras tarifárias estão sendo aniquiladas, pressupondo então, que as medidas TBT e SPS se tornem convenientes para encobrir o protecionismo, tornando esta uma questão muito relevante a ser explorada.

É importante que se conheça os mecanismos capazes de mitigar o problema, tanto para o Brasil garantir efetivo acesso a mercados, como para que esteja habilitado a restringir o comércio internacional de forma lícita, nos casos em que isto for necessário. O Acordo Geral sobre Tarifas e Comércio (GATT-1994) da OMC garante, com efeito, a possibilidade de se limitar o comércio internacional caso as importações atentem contra a segurança nacional. Do mesmo modo, o Acordo sobre Barreiras Técnicas da OMC também confirma esta exceção ao livre comércio (Prazeres, 2003).

Evidentemente, o emprego destas exceções está condicionado ao cumprimento de requisitos. Especificamente, os Acordos da OMC prevêem que exigências técnicas não poderão ser adotadas quando criam obstáculos desnecessários ao comércio internacional. Por esta razão, tais exigências não podem ser mais limitadoras ao comércio além do necessário para a obtenção do objetivo legítimo, no caso, a segurança nacional.

Portanto, o conhecimento e entendimento desses Acordos se tornam necessários, porque estes definem princípios para garantir a segurança nacional, evitar problemas à saúde do consumidor, e o mau uso das medidas técnicas, sanitárias e fitossanitárias. Sendo estes Acordos Internacionais, em âmbito da OMC, devem ser cumpridos pelos países (importadores e exportadores).

Castilho (1994), explica que tais barreiras se caracterizam pelo estabelecimento de normas visando a harmonização de regulações técnicas, padrões e normas de inspeção. Essas normas têm efeito restritivo ao comércio a partir do momento em que diferem entre os países, podendo ser compulsórias ou voluntárias. Contemplam também normas industriais, de segurança, embalagens e de mídia. Até 1994, antes do estabelecimento do Acordo sobre Medidas Sanitárias e Fitossanitárias (SPS), o Código 
de Padrões (Standards Code) tratava ambas as barreiras, técnicas e sanitárias, conjuntamente.

Na Rodada Tóquio do GATT (1973-79) foi estabelecido o Standards Code (Código de Normas), de adesão voluntária, cujo escopo era disciplinar o tema de regulamentos técnicos, incluindo as medidas de natureza sanitária. A disciplina sobre este assunto avançou durante a Rodada Uruguai (1986-1993), quando o Standards Code foi sucedido por dois novos acordos, o de Medidas Sanitárias e Fitossanitárias (Sanitary and Phytosanitary Agreement (SPS) e o Acordo sobre Barreiras Técnicas ao Comércio (Agreement on Technical Barriers to Trade (TBT). A diferença básica entre os dois está em seus objetivos e, portanto, em sua abrangência (Miranda et al., 2004).

O Acordo SPS aplica-se a todas as medidas sanitárias e fitossanitárias que possam afetar o comércio, direta ou indiretamente e estabelece que os países têm o direito de adotar medidas sanitárias e fitossanitárias que sejam necessárias para a proteção da vida ou saúde humana, animal ou vegetal, desde que tais medidas não sejam inconsistentes com os princípios do Acordo. Segundo Thorstensen (1999) citado em Miranda et al. (2004), essas medidas compreendem leis, regulamentos, decretos, exigências e procedimentos, métodos de processamento e produção, testes, inspeção, certificação, tratamento de quarentena, transporte, métodos estatísticos, amostragem e exigências de empacotamento e embalagem, diretamente ligados à segurança alimentar.

O Acordo TBT tem entre seus objetivos garantir que as normas e padrões técnicos elaborados e aplicados pelos países, tais como exigências de embalagem e rotulagem e procedimentos para avaliação de conformidade com as normas e padrões técnicos, não criem obstáculos desnecessários ao comércio internacional. Conforme estabelece em suas provisões gerais, abrange tanto produtos industriais quanto agrícolas. Contudo, as disposições desse Acordo não se aplicam às medidas sanitárias e fitossanitárias definidas no Acordo SPS.

Segundo Miranda et al. (2004), o TBT aplica-se a características do produto e aos métodos de processo e produção que tenham efeito sobre as características e qualidade do produto, tendo como objetivo garantir padrões de qualidade e de segurança e proteção à 
saúde dos consumidores, bem como de proteção ao ambiente, objetivos expressos no TBT como legítimos.

\subsubsection{Notificações: instrumento para transparência no comércio internacional}

$\mathrm{Na} \mathrm{OMC}$, a notificação consiste em um instrumento que visa a dar transparência ao sistema multilateral de comércio, possibilitando a qualquer membro a verificação do cumprimento e evolução dos acordos firmados. Por exemplo, o Acordo sobre Agricultura prevê a apresentação anual pelos membros da OMC de notificações sobre tarifas, quotas tarifárias, de medidas de salvaguardas especiais e de subsídios à exportação. A maioria dos acordos da OMC prevê algum tipo de notificação por parte dos membros da organização, que é um dos mecanismos para garantir a transparência (Icone, 2004).

Os Acordos SPS e TBT estabelecem o procedimento de notificação pelo qual os países membros, quando criarem novas normas e padrões técnicos ou alterarem as existentes, de forma que essas se tornem diferentes dos aceitos internacionalmente, devem apresentá-los ao demais países membros, notificando ao Secretariado da OMC. A OMC informa aos demais países, com antecedência suficiente para que todas as partes tenham tempo para se manifestar sobre o padrão/regulamento criado, podendo vir a contestar a medida. Esse mecanismo visa atender a um dos princípios básicos do TBT e SPS, que é o da transparência. Pode-se observar um modelo de notificação no anexo E.

\subsubsection{Acordo TBT, descrição e importância}

Para evitar uma diversidade excessiva, o Acordo encoraja os países a adoção de normas internacionais para elaboração de seus regulamentos técnicos (TBT 2.5) e procedimentos de avaliação da conformidade, bem como a harmonização de suas normas nacionais com as internacionais. Quando isto ocorre, presume-se, salvo 
refutação, não haver intenção protecionista por parte do país. Há também um incentivo à participação dos países-membro nas instituições de normalização internacionais apropriadas, para a elaboração de normas internacionais para os produtos para os quais tenham adotado, ou prevejam adotar, regulamentos técnicos (Fermam, 2004).

O Artigo 2.2 do Standards Code e o Artigo 2.4 do Acordo TBT estabelecem que quando da emissão de um regulamento técnico, o Estado deve tomar como base normas internacionais, exceto quando estas (a normas internacionais) forem incompetentes ou ineficazes para cumprimento dos objetivos legítimos, tais como constam nestes documentos oficiais (Tanno \& Ferracioli, 2004).

Em 1995, a OMC substituiu o GATT como foro multilateral para negociação de questões comerciais. Com a Rodada do Uruguai houve maior rigor ao cumprimento das obrigações assumidas pelos seus estados membros, uma vez que há a possibilidade do Estado sofrer penalidades caso descumpra com suas obrigações.

O governo brasileiro, preocupado em se adaptar à evolução do mercado internacional aprovou a Resolução No $5 / 95$ em 4 de setembro de 1995, que ampliou as funções do Inmetro e atribuiu-lhe a responsabilidade de notificar, aos organismos internacionais, toda proposta de elaboração da regulamentação técnica federal (Tanno \& Ferracioli, 2004).

A discussão sobre barreiras técnicas ao comércio internacional imprime a necessidade de analisar as formas existentes de protecionismo. De acordo com Barral (2002), protecionismo é o conjunto de medidas tomadas no âmbito do comércio internacional para modificar o seu fluxo. Tal questão é abordada de formas distintas por outros autores, muitas vezes com pequenas, mas significativas variações, dependendo evidentemente do uso que o autor faz da informação.

Segundo Ferracioli (2002), exigências técnicas, voluntárias ou obrigatórias, são utilizadas como formas dissimuladas de proteção de mercados nacionais, revelandose importante fator limitador à livre circulação de mercadorias. No entanto, destaca que 
o conceito de "barreiras técnicas" não é bem compreendido, sendo associado às dificuldades de exportadores em cumprir exigências técnicas.

Segundo Oliveira (2002), por trás da aparente promoção do intercâmbio comercial via eliminação de barreiras tarifárias há o jogo de consolidação e expansão de barreiras invisíveis ao comércio, que este define como: "Mecanismos não tarifários que objetivam o bloqueio do acesso de países menos desenvolvidos aos mercados do Primeiro Mundo".

Ferracioli (2004), destaca que o benefício conquistado no comércio internacional com a redução de entraves, tarifas, subsídios, questões aduaneiras, etc. se contrapõem ao surgimento de outras barreiras, mais sutis, de difícil identificação, mas com a mesma função: proteger mercados. Estas barreiras são chamadas de barreiras técnicas.

Prazeres (2003), também avança dizendo que no âmbito da OMC um Estado membro tende a tomar medidas de proteção (do tipo protecionismo ao mercado) com as barreiras não tarifárias, pois as tarifárias são facilmente identificadas. Contudo as barreiras não tarifárias, embora reduzidas a poucas hipóteses lícitas, tendem a ser cada vez mais utilizadas.

Thorstensen (2003), afirma que é prática usual dos governos a adoção de regras sobre regulamentos e normas técnicas aplicados sobre bens produzidos internacionalmente e sobre importados, com objetivo de garantir padrões de qualidade, de segurança, de proteção à saúde e ao meio ambiente. No entanto, estas regras podem se transformar em barreiras ao comércio internacional, tendo em vista a redução de tarifas e as pressões políticas para proteção de setores menos competitivos.

Segundo Thorstensen (2003), o critério para que normas técnicas não se transformem em barreiras comerciais é que estas estejam baseadas em regulamentos e padrões internacionais. 
Segundo o Inmetro (2004), a publicação do Senai e do Inmetro descreve as barreiras técnicas como um subgrupo das barreiras não tarifárias, que por sua vez fazem parte do grupo das barreiras denominadas barreiras comerciais. A definição para barreiras técnicas citada, segundo a $\mathrm{OMC}$, é: "Barreiras Técnicas às Exportações são barreiras comerciais derivadas da utilização de normas ou regulamentos técnicos não transparentes ou que não se baseiam em normas internacionalmente aceitas ou ainda, decorrentes da adoção de procedimentos de avaliação da conformidade não transparentes e/ou demasiadamente dispendiosos, bem como de inspeções excessivamente rigorosas".

Segundo Garrido (2004), o TBT considera que um regulamento técnico adotado por um dado país, poderá ser considerado uma barreira técnica se divergir de uma norma técnica internacional existente no que se refere às exigências para se atingir os objetivos legítimos que tenham justificado a promulgação desse regulamento. Bem como considera uma barreira técnica a que decorrer da adoção de procedimentos de avaliação da conformidade não transparentes, ou demasiadamente dispendiosos, bem como de inspeções excessivamente rigorosas.

A definição de barreiras técnicas neste caso é mais abrangente, pois não se considera somente, para fins práticos, como barreira técnica, aquela decorrente da intervenção direta do poder público do país importador, através da regulamentação técnica. Exigências dos compradores quanto ao cumprimento de normas, por exemplo, constituem-se em dificuldades de fato. Neste tipo de abordagem está implícito que as barreiras técnicas podem ser superadas não sendo sempre ilegítimas.

Nesta linha pode-se dizer que as barreiras técnicas são resultados de exigências técnicas estabelecidas pelos compradores para os produtos ou serviços, seja em relação às suas características intrínsecas, seja pela necessidade de ter, de alguma forma, de demonstrar o atendimento a esses requisitos (por exemplo, a realização de ensaios ou inspeções).

Pode-se dividir as barreiras técnicas em duas grandes categorias (Garrido, 2004): 
a) Barreiras decorrentes de razões oficiais;

b) Barreiras decorrentes de razões voluntárias.

No ambiente das barreiras decorrentes de razões oficiais os regulamentos técnicos promulgados pelos poderes públicos impõem requisitos técnicos que são obrigatórios para que os produtos por eles abrangidos possam ter acesso ao respectivo mercado, ou estabeleçam regras para os procedimentos de avaliação da conformidade correspondentes.

Assim, para poder fornecer a esse mercado, os regulamentos técnicos obrigatoriamente têm que ser atendidos. Se estes regulamentos estiverem sendo destinados a assegurar que os produtos ou serviços fornecidos nesses mercados atendam a requisitos de segurança de pessoas e bens, saúde, segurança sanitária e fitossanitária, prevenção da concorrência desleal, proteção do meio ambiente, segurança nacional, entre outros, então seus objetivos são considerados legítimos, conforme definido no Acordo sobre Barreiras Técnicas da OMC.

Mesmo nas situações em que as barreiras técnicas são consideradas legítimas, uma vez que no Acordo sobre Barreiras Técnicas da OMC as medidas com objetivos legítimos são aceitas, pode-se deparar com medidas excessivas em relação aos aspectos que se pretendia assegurar, ou seja, passam a ser discriminatórias, ou vão além dos aspectos legítimos referidos, constituindo-se então em medidas de caráter protecionista (Garrido, 2004).

Existem barreiras que são estabelecidas pelo mercado, sem qualquer interferência direta do Estado. As práticas adotadas têm relação direta com os hábitos, culturas e/ou necessidades e expectativas, as quais são normalmente traduzidas por requisitos técnicos, especificados em normas e especificações. Da mesma forma que os procedimentos de avaliação da conformidade, associados às necessidades de assegurar a conformidade dos produtos e serviços a estes requisitos/especificações, são utilizados de tal forma que se tornam exigências de fato. Desta maneira, quem pretender exportar para 
determinados mercados, se quiser ter sucesso, deverá atender a esses requisitos consagrados. Os requisitos podem acabar por se constituir em barreiras técnicas, no amplo sentido, sempre quando forem diferentes dos consagrados no país de origem dos produtos ou serviços que se quer exportar.

Nesta situação não se discute a questão da legitimidade, pois qualquer mercado comprador, no caso também importador, pode estabelecer os requisitos que julgar como necessários para atender às suas necessidades.

As barreiras técnicas, principalmente no amplo sentido, sempre existiram, embora a sua importância relativa tenha aumentado em virtude da constante diminuição das tarifas. Várias destas barreiras não eram percebidas antes devido à existência de elevadas tarifas que, por si só, já inviabilizavam o comércio.

Do ponto de vista da competitividade e do acesso a mercados, na medida em que mais e mais mercados exigem requisitos técnicos diferentes para os mesmos produtos ou serviços, esta multiplicidade de exigências cria sérias dificuldades de acesso aos mercados e gera custos adicionais crescentes, até inviabilizando o acesso.

Por fim pode-se dizer que uma barreira técnica é caracterizada pela tomada de decisão, por meio de instrumentos técnicos, de impedir o fluxo de comércio, sem o uso de argumentos considerados legítimos, e que imprima discriminação a determinados produtos.

Segundo a conclusão de Garrido (2004), do ponto de vista da exportação (externo), as barreiras técnicas inviabilizam a geração de emprego e renda, limitam a produção à demanda do país produtor, deslocam o eixo de investimentos para outros setores produtivos e podem trazer um papel marginal, em termos de comércio internacional, para este país. Já do ponto de vista da importação (interno), as barreiras técnicas protegem os produtores nacionais e, num primeiro momento, os empregos, mas desestimulam os investimentos, levam à diminuição da competitividade deste país, 
estimulam a prática de elevação de preços e podem influenciar negativamente o desenvolvimento de pesquisas, bem como o avanço científico e tecnológico do país.

Sobre Barreiras técnicas, segundo Oliveira (2002), usar um novo acordo somente para tornar ainda mais rígidas as obrigações dos países menos desenvolvidos, ou para ampliar os espaços de mercado já atingidos pelo monopólio temporal conferido aos titulares de patente, seja via prorrogação de prazo da patente concedida seja pela ampliação da abrangência de seu escopo, constitui mais uma forma de barreira técnica para impedir o crescimento econômico autônomo dos países menos desenvolvidos.

\subsubsection{Medidas técnicas relevantes no contexto da produção de frutas brasileiras}

Para que a adoção de uma norma, regulamento técnico ou procedimento de avaliação da conformidade não acarrete a criação de obstáculos desnecessários ao comércio, segundo o TBT, alguns requisitos devem ser verificados. Dentre estes requisitos, segundo o autor Fermam (2004), encontra-se:

1) Embasamento em normas internacionais: isso pressupõe que o HACCP tenha sido elaborado por instituições de normalização internacionais. A questão, então, passa a ser o consenso sobre a definição de uma "instituição de normalização internacional".

Geralmente entende-se que quatro organismos de normalização atendem a esses requisitos: a ISO (International Organization for Standardization), a Comissão do Codex Alimentarius, a IEC (International Electrotechnical Commission) e a ITU (International Telecommunication Union). No caso do presente estudo, a ISO é a imprescindível para frutas.

O sistema HACCP é parte integrante da norma "Código Internacional de Práticas Recomendado para Princípios Generais de Higiene dos Alimentos” Assim, o 
HACCP não viola o Artigo 2.5 do TBT e, portanto, não cria um obstáculo desnecessário ao comércio;

2) Atendimento aos objetivos legítimos: a adoção do HACCP pelos países gera restrições ao comércio que não existiam anteriormente. Para que isso não se constitua numa barreira técnica, é necessário que o HACCP tenha sido elaborado, adotado ou aplicado, visando objetivos de segurança nacional; a prevenção de práticas enganosas; a proteção da saúde ou segurança humana, da saúde ou vida animal ou vegetal, ou do meio ambiente.

Segundo a concepção de Ferman (2004), o HACCP possui inúmeras vantagens em relação ao processo tradicionalmente usado de inspeção alimentar. No processo tradicional, a inspeção baseia-se nos sentidos da visão, olfato e tato para detectar perigos (lesões, contaminação, etc.), sendo somente concebida quando os perigos eram a contaminação macroscópica e os animais doentes.

Percebe-se então, que o sistema HACCP, ao contrário da inspeção tradicional, é preventivo, onde ações são tomadas antes que o problema ocorra, concentrando o controle nos pontos críticos para a inocuidade do produto.

O objetivo desta discussão é fornecer informações sobre as atuais discussões do comércio internacional envolvendo regras como etiquetagem e rotulagem (que estão dentro das discussões técnicas), por exemplo. Tais discussões têm sido promovidas tanto no Comitê sobre Barreiras Técnicas ao Comércio (CTBT) quanto no Comitê sobre Comércio e Meio Ambiente (CTE).

No âmbito da $\mathrm{OMC}$, as questões relacionadas à etiquetagem de alimentos são tratadas em outros Comitês como o Comitê sobre Medidas Sanitárias e Fitossanitárias (Comitê SPS) e também no CTBT em decorrência das definições de regulamento e normas técnicas adotadas no Acordo sobre TBT (Tanno, 2004). 
No CTBT, várias exigências sobre etiquetagem têm sido denunciadas como mais detalhistas do que necessário ou envolvendo métodos ou processos de produção que não revelam características dos produtos, sendo, portanto, medidas que não estão de acordo com o objetivo do TBT de evitar a criação de barreiras técnicas ao comércio internacional.

Percebendo o potencial protecionista das crescentes exigências relativas à etiquetagem, o Comitê TBT (ainda GATT), em 1992, determinou que todos os países teriam a obrigação de notificar todos os requisitos obrigatórios para etiquetagem que não são baseados em norma internacional relevante e que podem ter efeito negativo no comércio com outros países (Tanno, 2004).

Por outro lado, segundo o mesmo autor, a análise das regras de comércio aplicável aos requisitos de etiquetagem vem também sendo realizada, por instrução da Declaração Ministerial de Doha (WT/MIN (01)/17), de novembro de 2001, pelo Comitê sobre Comércio e Meio Ambiente.

A etiquetagem e rotulagem são exemplos de exigências dos mercados consumidores (importadores) que tem sido muito requerida em acordos como TBT, CTE e SPS, o que vem aumentando o potencial para que esta medida seja utilizada como uma barreira técnica ao comércio internacional.

Nestas discussões, é essencial o conhecimento das dificuldades que podem advir de requerimentos feitos em legislações domésticas elaboradas com o intuito de cumprir com as obrigações assumidas em acordos ambientais multilaterais, havendo exigências técnicas relacionadas a métodos e processos de produção não encontrados no Acordo TBT (Tanno, 2004).

A discussão sobre o tema etiquetagem e rotulagem torna-se cada vez mais presente na medida em que nas negociações sobre agricultura, os aspectos não-tarifários se mostram como assuntos de sérias discussões entre os Estados membros da organização. É preciso que sejam consideradas as relações entre temas vinculados às 
negociações, como os princípios da precaução e a multifuncionalidade ${ }^{21}$ sobre $^{2}$ agricultura e temas associados ao TBT, como a etiquetagem e rotulagem obrigatória.

Principalmente para o Brasil que tende a se tornar até o final desta década o maior produtor de frutas frescas, este tema é de extrema importância dado o fato dos produtores brasileiros de frutas pretenderem atender ao mercado (nacional e internacional), que incluem alimentos in natura, alimentos orgânicos e alimentos geneticamente modificados. São mercados exigentes e minuciosos quando o assunto é o que os consumidores estão adquirindo, que tipo de alimento, se é inócuo à saúde ou não, preocupando-se com a informação da etiqueta, rótulo e embalagem do alimento.

No programa PIF do Brasil toda fruta que receber o selo com a logomarca PIF, o consumidor terá a tranqüilidade de consumi-la porque saberá o que está consumindo (através das informações contidas na embalagem), além da garantia da fruta ser inócua à sua saúde, ou seja, livre de resíduos químicos e outros problemas fitossanitários.

\subsubsection{Discussões sobre o Acordo SPS}

Dentre os diversos Acordos da OMC, consta o de Medidas Sanitárias e Fitossanitárias. Ele estabelece as regras básicas para a normativa sobre a inocuidade dos alimentos, para a saúde dos animais e a preservação dos vegetais. Estas devem se basear em princípios científicos (SPS 2.2), quando da sua elaboração.

${ }^{21}$ A multifuncionalidade enuncia que a um Estado deve ser resguardado o direto de exigir o cumprimento de medidas que terão impacto no comércio internacional se estas tiverem como objetivo a preservação de aspectos relativos à história, tradição, cultura, paisagem, recreação e monitoramento sanitário e ambiental que estejam relacionadas às atividades agrícolas (Tanno, 2003). 
Todos os países aplicam medidas para garantir a inocuidade dos produtos alimentícios destinados ao consumo humano e para evitar a propagação de pragas ou enfermidades entre os animais e os vegetais. Estas medidas sanitárias e fitossanitárias podem adotar muitas formas: por exemplo, podem referir-se à necessidade de que os produtos procedam de zonas livres de enfermidades, à inspeção dos produtos, a seu tratamento ou elaboração por meios específicos, ao estabelecimento de níveis máximos autorizados de resíduos de pesticidas ou à exclusão do uso de determinadas substâncias como aditivos alimentares.

O Acordo SPS incentiva os membros a utilizarem normas, diretrizes e recomendações Internacionais (SPS 3.1), quando existirem, na elaboração de suas medidas sanitárias e fitossanitárias visando à harmonização das mesmas. Deste modo, presumir-se-á que tais medidas são compatíveis com as disposições pertinentes ao Acordo SPS e do GATT 1994. Incentiva-se também a participação dos países-membros em organizações internacionais competentes e seus órgãos auxiliares, como a Comissão do Codex Alimentarius (Fermam, 2004).

O impulso para a criação do Acordo SPS durante a Rodada Uruguai foi por dois fatores: 1) O Código Padrão era visto como fundamentalmente falho e incapaz de evitar o aumento da tensão entre os principais parceiros de comércio, Estados Unidos e União Européia; 2) a liberalização de barreiras tarifárias ao comércio agrícola, que pressupunha que medidas como SPS corriam o risco de serem freqüentemente usadas para propostas protecionistas (Jensen, 2001).

Exportadores (países em desenvolvimento) buscando aumentar sua fatia de mercado poderiam ter problemas se os importadores (países desenvolvidos) usassem as medidas do Acordo SPS de forma protecionista.

O Acordo SPS estabelece regras internacionais de como aplicar as medidas SPS. Segundo Jensen (2001), de um lado admite-se que países usem de forma correta a proteção de riscos contra a vida e saúde humana, animal e de plantas. De outro lado, é 
necessário impedir que os países usem estes riscos de forma errônea, criando barreiras desnecessárias ao comércio.

Em resumo, a proposta do Acordo é permitir a legitimidade da proteção da vida e saúde enquanto evita o aumento do protecionismo ${ }^{22}$ ilegítimo.

Os dois princípios básicos do Acordo são: (i) princípio da não discriminação e (ii) princípio da justificação científica. O princípio da não discriminação é descrito no Artigo 2.3 do Acordo (este princípio equivale ao do GATT da nação menos favorecida). A medida não deve ser discriminatória, contra ou entre os parceiros de comércio, mais do que o necessário para alcançar o objetivo de proteção sanitária e fitossanitária. $\mathrm{O}$ princípio da justificação científica de medidas SPS está descrito no Artigo 2.2 (Jensen, 2001).

O Acordo SPS, segundo Jensen (2001), também contém além dos princípios gerais (não discriminação, e justificação científica) instrumentos que são usados para alcançar tais objetivos. Estes instrumentos são:

a) Risco de taxação;

b) Regras na colocação do nível de proteção;

c)Exceção no caso de evidências insuficientes;

d) Harmonização;

e) Equivalência;

f) Regionalismo:

g) Transparência:

${ }^{22}$ Protecionismo é definido como barreiras ao comércio além, acima do que se necessita para desejar um nível de proteção. 
As dificuldades na exportação sobre o aumento rígido de medidas SPS vão se multiplicando particularmente em países em desenvolvimento. O custo envolvido inclui ambos, o custo de produção, de respeitar as exigências SPS, e o custo de conformidade, ou seja, de estar se fazendo a produção de modo garantido, respeitando as medidas SPS.

Enquanto as exigências SPS aumentam o custo de produção, como exigências de novos insumos e troca de tecnologia, o custo de conformidade inclui o custo de certificação e controle. Sendo que os custos de respeitar as medidas SPS, são maiores em países em desenvolvimento do que em países desenvolvidos. Segundo a opinião de Jensen (2001), o acesso à tecnologia de ponta é mais restrito em países em desenvolvimento e o setor privado e público que certifica e controla a conformidade é subdesenvolvido.

O Acordo SPS elegeu as normas, diretrizes e recomendações do Codex como sendo medidas que devem ser preferencialmente adotadas pelos países com vistas a facilitar o comércio de alimentos. Com isso, há o reconhecimento de que as normas do Codex possuem base científica sólida (Jensen, 2001).

Sendo assim, o Codex Alimentarius é um ponto de referência mundial de grande relevância para consumidores, produtores, fabricantes de alimentos, organismos nacionais de controle de alimentos e o comércio internacional de alimentos (como mencionado no capítulo 2, item 2.3.1). Nele os países participam na harmonização e aplicação de normas relativas a alimentos em escala mundial, além da possibilidade de participarem na elaboração de normas alimentares de uso internacional.

\subsubsection{Medidas fitossanitárias relevantes para a produção de frutas}

Segundo o Artigo $2^{\circ}$. "Direitos e Obrigações Básicas", Parágrafo $1^{\circ}$ do Acordo SPS, "Os Membros têm direito a adotar as medidas sanitárias e fitossanitárias 
necessárias para proteger a saúde e a vida das pessoas e dos animais ou para preservar os vegetais, sempre que tais medidas não sejam incompatíveis com as disposições do presente Acordo" (Fermam, 2004). Deste modo, faz-se necessário verificar se o HACCP não é incompatível com o Acordo SPS. As disposições do SPS relevantes neste caso são:

1. Embasamento científico: pressupõe que o HACCP reflita o "estado da arte"em matéria de segurança alimentar. Segundo o $2^{\circ}$. Parágrafo de seu Preâmbulo, o HACCP é elaborado de acordo com princípios científicos. O Artigo intitulado "HACCP: A State-of-the-Art Approach to Food Safety" publicado na "FDA Consumer (periodical), December/1995”, afirma que o HACCP se baseia “em princípios científicos sólidos". No mesmo Artigo, é dito que "o HACCP tem sido aprovado pela Academia Nacional de Ciências dos EUA, pela Comissão do Codex Alimentarius e pelo Comitê Consultivo Nacional sobre Critérios Microbiológicos para Alimentos dos EUA" (Claudio R. Almeida citado em Fermam, 2004);

2. Embasamento em normas, diretrizes ou recomendações internacionais: o Anexo A (3.a.) do Acordo SPS define o tema, em matéria de inocuidade de alimentos, como sendo "as normas, diretrizes e recomendações estabelecidas pela Comissão do" Codex Alimentarius sobre aditivos alimentares, resíduos de medicamentos veterinários e pesticidas, contaminantes, métodos de análise e amostragem, e códigos e diretrizes sobre práticas em matéria de higiene" (Fermam, 2004).

O próprio Acordo SPS elege a Comissão do Codex Alimentarius, que incorporou as Diretrizes para aplicação do Sistema HACCP, como sendo "organização internacional competente". Assim, a adoção do HACCP é necessária para proteger a saúde e a vida das pessoas e dos animais ou para preservar os vegetais, e também, portanto, compatível com as disposições pertinentes do Acordo SPS. 


\subsubsection{União Européia: exigências técnicas e sanitárias}

Como se sabe, a política agrícola comum (PAC) da Comunidade Européia é caracterizada pelo alto nível de protecionismo, pois vem implementando a estratégia de legitimar a adoção de medidas comerciais protecionistas através do princípio da precaução $^{23}$ e pela multifuncionalidade (Tanno, 2004).

Na interpretação do artigo 5.7 do Acordo do SPS, o princípio da precaução é defendido como justificativa legítima para o requerimento de exigências técnicas, ou seja, a proposta européia é que, a despeito de existir incerteza científica quanto à exata necessidade de exigir uma medida que terá impacto no comércio (ex. uma etiqueta), esta poderá ser legitimamente feita e mantida durante todo o tempo em que as avaliações científicas são conduzidas (Tanno, 2004).

De acordo com a autora, em relação à interpretação do artigo 2 do TBT, a União Européia propõe que passe a ser considerado como um objetivo legítimo àquele de prover informação ao consumidor, o que permitiria que este passasse a ser informado sobre métodos e processos de produção que não revelam características dos produtos. Portanto, a aceitação da proposta européia introduziria significativas mudanças sobre as próprias provisões do Acordo TBT. Os objetivos declarados deste regulamento são a prevenção da ocorrência de práticas enganosas e a proteção do consumidor europeu.

Outras considerações importantes apresentadas pela União Européia sobre a relação entre as provisões do TBT e as exigências de etiquetagem podem ser analisadas no Documento (G/TBT/W/150), de 2 de novembro de 2000, que são notificações. Neste, a União Européia propõe que a discussão sobre o assunto envolva três medidas: em primeiro lugar, a realização de um levantamento de informações pertinentes à etiquetagem, de forma a permitir a identificação de necessidades e dificuldade

\footnotetext{
${ }^{23}$ O princípio da precaução está presente nas propostas da União Européia para interpretação do artigo 5.7 do Acordo sobre Medidas Sanitárias e Fitossanitárias (Acordo SPS) e do artigo 2 do Acordo TBT.
} 
envolvendo tais exigências e as regras de comércio acordadas na $\mathrm{OMC}$; em segundo lugar, deve ser feita uma análise dos trabalhos realizados em fóruns internacionais (ISO e Codex Alimentarius) sobre os objetivos e políticas de etiquetagem e, por último, deve ser considerada a possibilidade de desenvolver diretrizes multilaterais para os esquemas de etiquetagem. Tais diretrizes deverão clarificar como seriam mais bem aplicadas as provisões do TBT e como os esquemas de etiquetagem podem ser utilizados sem que acarretem a criação de barreiras desnecessárias ao comércio.

Uma pertinente questão apontada pela União Européia diz respeito às dificuldades enfrentadas pelos países em desenvolvimento em cumprir as exigências de etiquetagem (WT/CTE/W/212 ou G/TBT/W/175, de 12 de junho de 2002). Como é sabido, tais países, por estarem em estágio ainda insatisfatório de desenvolvimento tecnológico, não conseguem adotar os métodos e processos de produção requeridos pelos países desenvolvidos (Tanno, 2004).

A posição da Comunidade Européia em relação a este problema é indicar que a etiquetagem ambiental pode representar para os países menos desenvolvidos uma oportunidade de acesso a mercados. É oportuno mencionar que, com o intuito de ganhar apoio dos países menos desenvolvidos às suas propostas, a União Européia tem vinculado a resolução das dificuldades destes estados à promoção de programas de assistência técnica.

Contudo, é relevante mencionar que a possibilidade de isto vir a acontecer parece ser pequena já que, no documento WT/CTE/W/225, a União Européia afirma que uma medida que pode ser tomada para evitar que a exigência de mercado por uma etiqueta seja uma barreira ao acesso de produtos de países menos desenvolvidos é que estes busquem, junto aos países desenvolvidos, a permissão para utilizar suas etiquetas ambientais (Tanno, 2004). 


\subsubsection{Estados Unidos: exigências técnicas e sanitárias}

No que diz respeito aos efeitos sobre o comércio internacional, o documento americano discorre sobre a possibilidade de exigências acabarem por contribuir para acentuar segmentações de mercado e perdas na economia de escala e, por fim, constituírem barreiras técnicas (Tanno, 2004).

Uma outra questão levantada pelos Estados Unidos diz respeito às provisões do TBT para transparência, (documento G/TBT/W/165, de 25 de junho de 2001 e G/TBT/W/29, de 18 de junho de 1996). Apesar de existir uma recomendação para que sejam notificados todos os regulamentos técnicos de etiquetagem, independente do tipo de informação a ser veiculada através da etiqueta, não há recomendação semelhante para as exigências de natureza voluntária (feitas pelos importadores de modo particular).

Conseqüentemente, não há um mecanismo que permita ao exportador participar no processo de elaboração de um esquema de rotulagem voluntário, o que facilita que tais esquemas funcionem, em realidade, como barreiras técnicas ao comércio.

Os Estados Unidos, para este caso, examinam a possibilidade das etiquetas tais como exigidas atualmente, tanto de caráter voluntário ou compulsório, serem substituídas por formas menos restritivas ao comércio para informar o consumidor, como campanhas de conscientização e requerimento de etiquetas menos detalhadas (Tanno, 2004).

A Lei Agrícola de 2002 estabeleceu um requisito de rotulagem para país de origem, conhecido pela Sigla "COOL" (country of origin labeling), aplicável à comercialização varejista de cortes de carne bovina, ovina e suína, peixe, frutas, vegetais e amendoim. Segundo informações obtidas na Aduaneiras (2003), a lei será voluntária até setembro de 2004 e obrigatória a partir de 30/09/2004, ou seja, resultando em custos adicionais para varejistas, importadores consumidores, associados à verificação da origem do produto e das despesas adicionais de rotulagem. 
A posição norte-americana é de não apoio às posições européias, fato que pode ser compreendido como uma decorrência das suas próprias políticas comerciais, em que a etiquetagem tem sido exigida, muitas vezes, de forma arbitrária, não chegando nem ao mesmo a ser legitimada por um princípio mais sofisticado como os princípios da precaução ou da multifuncionalidade presentes nas propostas da União Européia (Tanno, 2004).

Os EUA contam com inúmeros regulamentos federais, estaduais e municipais aplicáveis à qualidade, sanidade, inocuidade tanto de produção nacional quanto das importações. Esses regulamentos incluem padrões de rotulagem, embalagem, práticas sanitárias, de boa fabricação, aditivos, pesticidas e corantes em alimentos, certificação de farmacêuticos, produtos biológicos, níveis de acidez em enlatados, padrões industriais e sistemas de inspeção oficiais (Aduaneiras, 2003).

Observações do conselho Nacional de Pesquisas (NRC) dos EUA evidenciam as potenciais barreiras técnicas de acesso ao mercado representadas pelo sistema de normas técnicas, avaliação de conformidade e certificação dos EUA. A complexidade do sistema torna custoso para o exportador estrangeiro (principalmente países em desenvolvimento), especialmente o pequeno empresário, a identificação de normas técnicas e os procedimentos de avaliação de conformidade e certificação (Aduaneiras, 2003).

Os obstáculos enfrentados pelos exportadores estrangeiros na comercialização de seus produtos persistem, devido à lenta adoção por parte dos EUA de se adequar às normas técnicas estabelecidas por organismos internacionais. Isto se dá pela alegação de equivalência técnica do regulamento interno EUA, na tentativa de tentar reverter o quadro mediante a implementação das disposições dos Acordos sobre Barreiras Técnicas ao comércio da OMC.

Atualmente, termos referentes à normalização passam a ser conceitos imprescindíveis para o convívio com as novas tendências para produtos agrícolas. Entretanto, vale ressaltar que a normalização não é um conceito novo, existindo desde os 
primórdios da civilização, quando o homem começou a realizar transações comerciais. Podemos descrevê-la como a aplicação de regras às atividades do homem, com as quais a humanidade vem, desde tempos remotos, procurando regular seus relacionamentos dentro da comunidade, em vista da necessidade de estimar dimensões, pesos e distâncias para construir, produzir e colher sua alimentação e intercambiar gêneros e produtos diversos.

Portanto o pano de fundo da presente dissertação é, de uma nova tendência normalizadora, diante de preocupações agroecológicas, de segurança alimentar e de segurança de alimento.

\subsection{Conscientização mundial para normas}

Num mundo globalizado, países se comunicam constantemente devido ao intenso fluxo do comércio internacional, e um importante facilitador deste comércio foi a utilização de normas, principalmente quando harmonizadas. Neste contexto, os processos de certificação são garantias de que os países seguem normas.

A Normalização, conhecida como organização sistemática das atividades pela aplicação de regras comuns, destacou-se principalmente a partir da Revolução Industrial, quando cresceu a necessidade de utilização de normas que permitissem a produção de peças intercambiáveis, em virtude da transformação da produção artesanal em fabricação de grandes lotes com produção de escala, passando a ser uma das bases das modernas sociedades industriais.

Por outro lado, a importância da normalização para as empresas estava fundamentalmente centrada nos diversos mercados nacionais, em que cada país desenvolvia o seu conjunto de normas para orientar o seu mercado interno. Desta maneira, o seu desenvolvimento acompanhava o próprio desenvolvimento industrial das nações, sendo muitas vezes percebida como uma atividade dos países desenvolvidos. 
Nos países em desenvolvimento, a normalização foi durante muitos anos considerada uma atividade de importância secundária.

Entretanto, diante de um mundo crescentemente globalizado, esta atitude mudou, e temos assistido a uma maior busca pela participação nos foros de normalização por parte das empresas, que vêm se conscientizando de que estar presente nos processos de elaboração de normas é vital para sua permanência em um mercado cada vez mais competitivo, tanto em nível nacional quanto internacional.

Pelo lado da demanda, as mudanças também se verificam no mesmo sentido. Os consumidores vêm se organizando em associações, exigindo cada vez mais que os produtos correspondam efetivamente ao valor que pagam, o que vem estimulando o desenvolvimento de normas técnicas que sirvam como base para o relacionamento de confiança entre as partes, isto é, entre a empresa e o consumidor.

Uma das definições de normas é a maneira de organizar as atividades pela criação e utilização de regras que visa contribuir para o desenvolvimento econômico e social, sendo que a criação destas deve ser efetuada com a participação dos diversos interessados nos seus resultados, ou seja, quem fornece, quem compra e outras partes, como o governo, os institutos de pesquisa, etc. Pode-se dizer então que a normalização é a auto-regulamentação da sociedade.

Num determinado mercado onde a "Avaliação da Conformidade" é uma exigência compulsória, principalmente quando estão em jogo questões como a saúde, a segurança do consumidor e do alimento ou o meio ambiente, um exportador (de alimentos) deve se preocupar em atender a essas exigências do mercado internacional, obtendo a certificação por um organismo de certificação aceito mundialmente ou no mercado de destino. Assim, um exportador deve se informar sobre as exigências de avaliação da conformidade num mercado específico para o qual deseje exportar seu produto para que este não sofra nenhum tipo de restrição fitossanitária. 
Portanto torna-se imprescindível o conhecimento das normas e regras mais importantes, no caso do presente trabalho, para frutas, pelos países exportadores, principalmente países em desenvolvimento que possuem vantagens comparativas na exportação de alimentos in natura, dado a intensa tendência de harmonização e/ou normalização e padronização mundial.

\subsubsection{A importância da utilização de conceitos para a normalização e certificação de alimentos entre os países}

No Brasil existe somente um Organismo Nacional de Normalização, a Associação Brasileira de Normas Técnicas $(\mathrm{ABNT})^{24}$ que elabora as normas técnicas. Atualmente existe o Sistema Brasileiro de Normalização (SBN), que foi criado no âmbito do SINMETRO, destinando-se ao desenvolvimento e coordenação das atividades de normalização e inter-relação com a regulamentação técnica. Pode-se verificar um quadro que resume a estrutura do Sistema brasileiro de normalização no Anexo F.

\subsubsection{Organismos responsáveis pela normalização e certificação no Brasil}

A International Standardization Organization (ISO) é uma organização, sediada em Genebra (Suíça), reconhecida e aceita internacionalmente no estabelecimento de normas técnicas desenvolvidas e avaliadas no âmbito de competência de suas delegações nacionais. Essas são formadas por especialistas em negócios, governo e outras organizações relevantes, que participam ativamente de comitês técnicos, apresentando pareceres em consenso com a posição oficial de seus países (ISO, 2005).

${ }^{24} \mathrm{O}$ processo de certificação da ABNT está estruturado em padrões internacionais, de acordo com ISO/IEC Guia 62/1997, e as auditorias são realizadas atendendo às normas ISO 10011 e 14011, garantindo um processo reconhecido e seguro (INMETRO, 2004). 
O Instituto Brasileiro de Normas Técnicas representa o Comitê Brasileiro de Certificação (CBC) (criado pela resolução CONMETRO n.8 de 24/08/92) na ISO e, assim possui além das responsabilidades atribuídas a seus membros, a de divulgar, avaliar e preservar a aceitação, o uso e integridade da marca ISO. O INMETRO possui acordo de reconhecimento com os membros do IAF (International Acreditation Forum) para certificar Sistemas da Qualidade (ISO 9000) e Sistemas de Gestão Ambiental (ISO 14001) e diversos produtos e serviços. Nesse sentido, o Inmetro pode treinar e habilitar instituições para o credenciamento (INMETRO, 2004).

A Associação Brasileira de Normas Técnicas (ABNT) é o organismo de certificação brasileiro, credenciado pelo INMETRO para atuação em certificação de sistemas de garantia de qualidade e de produtos no país. É uma entidade privada, independente e sem fins lucrativos, fundada em 1940, que atua desde 1950 no desenvolvimento de programas de certificação apropriados a diversas áreas da sociedade brasileira, em conformidade com os modelos internacionalmente aceitos e estabelecidos no âmbito do Comitê de Avaliação da Conformidade (CASCO) da ISO (INMETRO, 2004).

É um organismo reconhecido pelo governo brasileiro como Fórum Nacional de Normalização. A ABNT conta ainda com um quadro de técnicos capacitados e treinados para realizar avaliações uniformes, garantindo maior rapidez e confiança nos certificados (INMETRO, 2004).

A ABNT atua na área de certificação, atualizando-se constantemente e desenvolvendo "know-how" próprio. É reconhecida pelo governo brasileiro como Fórum Nacional de Normalização (Resolução n. ${ }^{\circ} 07$ do CONMETRO, de 24.08.1992), além de ser um dos fundadores e único representante da ISO, no Brasil. Além disso, é credenciada pelo INMETRO, o qual possui acordo de reconhecimento com os membros do International Acreditation Forum (IAF) para certificar Sistemas da Qualidade (ISO 9000) e Sistemas de Gestão Ambiental (ISO 14001) e diversos produtos e serviços. A 
ABNT oferece também, através de acordos com Organismos congêneres, certificados aceitos na Europa, Estados Unidos da América e outros países da América do Sul.

Também é membro fundador da Comissão Panamericana de Normas Técnicas (COPANT) e da Associação Mercosul de Normalização (AMN).

A ABNT é a única e exclusiva representante no Brasil das seguintes entidades internacionais: ISO, International Electrotechnical Comission (IEC) e das entidades de normalização regional: COPANT e AMN.

A ABNT é um Organismo Nacional que oferece credibilidade internacional. Todo processo de certificação da ABNT está estruturado em padrões internacionais, de acordo com ISO/IEC Guia 62/1997, e as auditorias são realizadas atendendo às normas ISO 10011 e 14011, garantindo um processo reconhecido e seguro. A ABNT conta ainda com um quadro de técnicos capacitados e treinados para realizar avaliações uniformes, garantindo maior rapidez e confiança nos certificados.

Segundo Chaim (2004), entre os benefícios resultantes da implantação de processos de certificação citam-se: a organização, simplificação e clareza de procedimentos e tecnologias disponíveis para a produção; a definição de métodos de controle, calibração e segurança de equipamentos; a disciplina na produção; organização e agilidade na recuperação de documentação de registros de acompanhamentos; controle de produtos, serviços e processos; racionalização de tempo gasto nas atividades; redução do consumo e do desperdício de recursos naturais não renováveis; melhoria de qualidade; diminuição de entraves associados a barreiras comerciais; proteção a saúde do consumidor e ao meio ambiente; segurança e confiabilidade no produto. Assim, os benefícios supra citados podem ser priorizados em função de três grandes demandas do consumidor: facilidade de identificação do produto, competitividade de mercado e credibilidade. 


\subsubsection{Normas}

Norma internacional é um documento estabelecido por consenso e aprovado por um organismo reconhecido que fornece, para uso comum e repetitivo, regras, diretrizes ou características para atividades ou para seus resultados, visando à obtenção de um grau ótimo de ordenação em um dado contexto (INMETRO, 2004).

São normas técnicas estabelecidas por um organismo internacional de normalização para aplicação em âmbito mundial. Existem diversos organismos internacionais de normalização, em campos específicos, como a ISO, na maioria dos setores, inclusive de alimentos e frutas.

Tais normas são reconhecidas pela Organização Mundial do Comércio como a base para o comércio internacional, e o seu atendimento significa contar com as melhores condições para ultrapassar eventuais barreiras técnicas.

Normas nacionais são normas técnicas estabelecidas por um organismo nacional de normalização para aplicação num dado país. No Brasil, as normas brasileiras (NBR) são elaboradas pela ABNT. Em cada país, existe um organismo nacional de normalização (ABNT, 2004).

A ABNT é reconhecida pelo Estado brasileiro como o Fórum Nacional de Normalização, sendo as normas elaboradas por tal órgão - NBR - reconhecidas formalmente como normas brasileiras, elaboradas nos Comitês Brasileiros da ABNT (ABNT/CB) ou em Organismos de Normalização Setorial (ONS) por ela credenciados (ABNT, 2004).

\subsubsection{Importância das normas internacionais}

Os Acordos TBT e SPS estabelecem uma série de princípios com o objetivo de eliminar entraves desnecessários ao comércio, como já mencionado, em particular às 
possíveis barreiras, relacionadas com normas técnicas, regulamentos técnicos e procedimentos de avaliação da conformidade que podem dificultar o acesso de produtos aos mercados, como mencionado no item 3.4.

Um dos pontos essenciais dos acordos internacionais é o entendimento de que as normas internacionais (aquelas elaboradas pelos organismos internacionais de normalização) constituem referência para o comércio internacional.

Os Acordos consideram que as normas internacionais não se tornem barreiras e recomenda que sejam usadas como referência para os regulamentos técnicos e que também sejam adotadas como normas nacionais.

Por esta razão assiste-se a uma forte tendência de os organismos nacionais de normalização adotarem as normas internacionais integralmente como normas nacionais. Hoje é extremamente importante para os agentes econômicos que querem ser competitivos seguirem de perto os trabalhos de normalização internacional e procurarem que seus produtos, serviços e sistemas de gestão atendam aos requisitos das normas internacionais. Um exemplo desta tendência são as normas da série ISO 9000.

As normas da ISO, são desenvolvidas nos seus comitês técnicos (ISO/TC), organizados numa base temática, com representantes dos seus membros. As representações são nacionais, e a aprovação das normas ISO é feita mediante votação entre os seus membros.

Segundo o INMETRO (2004), a participação brasileira nos trabalhos de normalização da ISO é efetuada através da ABNT. As normas ISO são voluntárias, cabendo aos seus membros decidirem se as adotam como normas nacionais ou não. A adoção de uma norma ISO como Norma Brasileira recebe a designação NBR ISO, sendo seus objetivos: facilitação da comunicação, simplificação, proteção ao consumidor, segurança, economia, e principalmente a eliminação de barreiras comerciais, provocando impactos sobre: 
1) Economia: melhor qualidade, quantidade e regularidade de produção; equilíbrio entre a oferta e a procura; aumento da competitividade no mercado nacional; redução de litígios; crescimento da produtividade nacional.

2) Produção: eliminação de desperdícios; padronização da documentação técnica; redução de custos; aumento da produtividade; base clara para a concorrência, evitando assim a concorrência desleal.

3) Consumo: acesso a dados técnicos padronizados; redução de preços; padronização de pedidos; possibilidade de comparação objetiva entre produtos, processos ou serviços; redução de prazos de entrega; garantia da qualidade, regularidade, segurança e integridade.

b) Harmonização do formato dos relatórios de ensaio, inspeção ou auditoria, bem como do procedimento de avaliação destes relatórios;

c) Harmonização dos procedimentos de credenciamento;

d) Métodos harmonizados de avaliação de pessoal, das disponibilidades de meios de medição e calibração de equipamentos de ensaios;

e) Métodos harmonizados de controle das condições ambientais laboratoriais

\subsubsection{Organismos de Certificação de Produto (OCP)}

São organismos que conduzem e concedem a certificação de conformidade de produtos, nas áreas voluntária e compulsória, com base em normas nacionais, regionais e internacionais ou regulamentos técnicos. São utilizados no setor de frutas e alimentos. 
Os critérios adotados pelo Inmetro para a acreditação desses organismos são baseados no ABNT ISO/IEC Guia $65^{25}$ e suas interpretações pelo IAF e IAAC.

Com estas questões em pauta, foram criados importantes organismos internacionais com o objetivo de estabelecer mecanismos para viabilização dos acordos de reconhecimento tais como: IAF; IATCA; ILAC; e IAAC. Pode-se verificar de forma resumida a importância e funções desses organismos internacionais no quadro do Anexo G.

\subsection{Desenvolvimento do contexto analítico: a teoria pura do comércio internacional e as barreiras técnicas ao comércio}

Até recentemente, a regulamentação dos alimentos vinha sendo mantida sob o domínio de tecnologistas de alimentos e reguladores governamentais. Aspectos referentes à eficiência econômica e aos possíveis efeitos distributivos das regulamentações não eram considerados quando a questão era assegurar a segurança dos alimentos (Antle, 1999).

Tem se tornado cada vez mais clara, no entanto, a tendência à convergência dessas duas áreas de interesse, o que tem mudado a forma de legislar, bem como a maneira pela qual a legislação sobre produtos alimentares vem sendo delineada e implementada.

Distinguem-se, facilmente, pelo menos dois importantes direcionadores dessas mudanças. Um primeiro refere-se à percepção diferenciada dos consumidores, que vem redirecionando suas preocupações concentradas, a princípio, na disponibilidade de alimentos, para a questão da qualidade dos alimentos, incluindo atributos como sabor, conteúdo nutricional e segurança (Antle; 1999). Um segundo direcionados refere-se à preocupação crescente com que os governos têm buscado melhorar a efetividade,

\footnotetext{
${ }^{25}$ ASSOCIAÇÃO BRAILEIRA DE NORMAS TÉCNICAS. Instruções normativas. http://www.inmetro.gov.br (28 jan. 2005)
} 
eficiência e transparência das regulamentações, tanto para reduzir os custos de programas governamentais, como para melhorar a eficiência e competitividade internacional de suas economias, segundo Jacobs (1997).

Nesse item introduzem-se, a princípio, noções básicas sobre as diferentes formas de interpretação e enquadramento das barreiras técnicas relativamente às barreiras convencionais, de natureza estritamente comercial, conforme literatura relacionada. A seguir, essas noções são complementadas por uma seleção de formas encontradas para abordar a análise das barreiras técnicas e sanitárias pelos autores que têm desenvolvido trabalhos para fundamentar a abordagem e mensuração empírica do impacto de barreiras técnicas ao comércio internacional.

\subsubsection{Aspectos teóricos que diferenciam as barreiras técnicas de barreiras convencionais ao comércio internacional}

Desde os seus primeiros desenvolvimentos teóricos formais, a teoria pura do comércio internacional tem preconizado que a evolução das relações de trocas entre os países implica em ganhos de bem estar econômico. Dessa maneira, quaisquer impedimentos ao livre comércio resultam em uma redução dos ganhos potenciais (Krugman \& Obstefeld, 1996). Embora essa proposição seja aceita para barreiras protecionistas convencionais, como no caso de tarifas e quotas, não deve ser aplicada de forma irrestrita quando se avaliam as barreiras técnicas ou sanitárias ao comércio (Roberts et al., 1999).

Diversos autores ressaltam que a análise das barreiras técnicas requer o emprego de um contexto analítico diferenciado, para que sejam considerados os não apenas os custos de uma regulamentação ou adoção de um padrão voluntário, quando esse afeta o comércio internacional, como também os benefícios inerentes à introdução da regulamentação (Thornsbury, 1999; Wilson, 2001; Antle, 1999). 
Segundo Wilson (2001), assim como as regulamentações, os padrões voluntários também podem ser interpretados como um recurso necessário quando ocorre falha de mercado. A menos que esses discriminem entre diferentes fontes de oferta, os padrões não incorporam custos secundários de comércio. Mesmo quando esse é o caso, o autor considera aconselhável ponderar se esse recurso pode ser o menos restritivo dentre as alternativas possíveis.

Não é claro, portanto, que os impactos ao comércio de todas as barreiras técnicas sejam ineficientes ou devam ser objeto de negociação multilateral. De fato, quando os custos da regulamentação são acompanhados de ganhos de eficiência suficientemente elevados para compensar as perdas, podem ser considerados como investimentos feitos pela sociedade para atingir uma regulamentação benéfica.

Em suma, não existe analogia para a proposta de que o livre comércio em bens é ótimo quando se considera a imposição de padrões e regulamentações.

De maneira geral, pode-se considerar que, pelo menos teoricamente, alguns padrões voluntários e praticamente todas as regulamentações mandatórias visam solucionar falhas de mercado, aproximando-se do conceito bens públicos (Thornsbury, 1999). Exemplos de iniciativas dessa natureza incluem a proteção ambiental, o saneamento público, e uma gama de aspectos de sanidade e saúde de plantas, animais e seres humanos. Considera-se pouco provável que uma firma individual absorva os custos dos investimentos em padrões dessa natureza. Mesmo que a firma tente sinalizar seu investimento através de alguma marca ou programa de marketing, outras firmas poderiam atuar como caronas ("free-riders") nos custos de desenvolvimento.

\subsubsection{Abordagens para a análise teórica do efeito de barreiras técnicas}

No caso de regulamentações ou introdução voluntárias de padrões o impedimento do comércio tem sido um desafio menor para o desenvolvimento teórico 
que a identificação do balanço entre os ganhos e perdas de bem estar econômico, quando os regulamentos técnicos abrangem o comércio internacional. Conforme se discute a seguir, um diferencial importante no contexto analítico das barreiras técnicas refere-se, a princípio, às suas várias dimensões: tecnológica, política e econômica (Thornsbury, 1999).

Nos primórdios do século 19, David Ricardo aprimorou a base teórica da economia internacional, tendo proporcionado uma importante contribuição aos desenvolvimentos nesse âmbito com a identificação da teoria das vantagens comparativas. Segundo o modelo de Ricardo, cada país deve produzir e exportar os bens e serviços para os quais for relativamente mais eficiente que outros países. Ao mesmo tempo, cada país deve importar os bens e serviços de países que os produzem de forma relativamente mais eficiente que se fossem produzidos internamente (Krugman \& Obstefeld, 1996; Feenstra, 2003). A realização do comércio sem a imposição de barreiras ou restrições implica em ganhos de bem estar econômico, se cada país se especializar e comercializar os bens para os quais detém maior eficiência produtiva, ou seja, sempre que o custo de oportunidade da produção de todos os bens superar o custo da especialização (Krugman \& Obstefeld, 1996; Feenstra, 2003).

Os desenvolvimentos teóricos que se seguiram, pautados na teoria de Hecksher-Ohlin, também consideraram aspectos diretamente relacionados à oferta para explicar o padrão do comércio internacional e os impactos positivos de sua expansão em um contexto de livre comércio, acrescentando relações que possibilitam a avaliação de impactos sobre a distribuição de renda entre os diferentes insumos empregados na produção dos bens comercializados no mercado externo (Krugman \& Obstefeld, 1996; Feenstra, 2003).

Esses fundamentos buscavam explicar a maneira pela qual indivíduos de uma economia poderiam ser beneficiados pelo estabelecimento e desenvolvimento do comércio global. 
No entanto, foi o princípio da compensação, introduzido por Kaldor em 1939 e aplicado por Samuelson em 1939 e $1962^{26}$, citados por Hong (2005), que possibilitou explorar, de uma maneira efetiva, o aspecto dos ganhos derivados do comércio. Visando identificar um critério que permitisse afirmar que uma situação é "melhor" do que a outra, esse princípio foi sugerido por Hotelling em $1938^{27}$ e empregado por Kaldor citados por Hong (2005). Em essência, o princípio da compensação é um critério que possibilita estabelecer que uma situação gerada por uma determinada mudança política é "melhor" que qualquer outra, fazendo a distinção entre aspectos de eficiência de aspectos distributivos.

O comércio internacional tem sido associado, porém, não apenas a um aumento na eficiência econômica, como também à possibilidade de permitir que os países participem de uma economia global (Hong, 2005). Ou seja, com o desenvolvimento do comércio internacional, promovem-se oportunidades para o investimento direto estrangeiro, que resulta no investimento em companhias e outros ativos estrangeiros. Teoricamente, as economias passam a crescer de forma mais eficiente, o que facilita a sua transformação em participantes competitivos de uma economia global. Além de moeda estrangeira, os países receptores de investimento direto estrangeiro (IDE) também podem internalizar conhecimentos. Os níveis de emprego podem aumentar e, teoricamente, conduzir a um aumento do produto nacional bruto. Para o país que investe, o IDE oferece capacidade de expansão e crescimento para as empresas, o que significa receitas mais elevadas.

No entanto, como é comum no contexto teórico, prevalecem visões opostas. No caso do comércio internacional, não existe consenso com respeito ao nível de controle que deve prevalecer sobre o comércio, no que se contrapõem o livre comércio e

${ }^{26}$ SAMUELSON, P.A., The gains from international trade. Canadian Journal of Economics and Political Sciences, May 1939.

KALDOR, N. Welfare propositions in economics. Economic Journal, Sep. 1939.

${ }^{27}$ HOTELLING, H. The general welfare in relation to problems of taxation and compensation principle 17 the decision may concern optimum distribution of incomes at a specific point in time or over a period of time that involves the marginal rate of time preference and the marginal productivity of waiting. 
o protecionismo. O livre comércio é a mais simples das duas teorias, envolvendo uma abordagem de laissez-faire, sem restrições sobre o comércio. A principal idéia que sustenta essa teoria é que a oferta e a demanda pelos fatores, operando de forma global, devem assegurar a obtenção da produção de maneira eficiente. Dessa forma, não se considera necessária qualquer ação ou interferência que resulte em proteção ou promoção do comércio e crescimento, uma vez que as forças de mercado conduzem, automaticamente, a tal resultado.

O protecionismo, ao contrário, considera que a regulação do comércio internacional é importante para assegurar que os mercados funcionem adequadamente. Os defensores dessa teoria acreditam que as ineficiências de mercado podem impedir ou reduzir os benefícios do comércio internacional, visando, por meio da intervenção, direcionar o funcionamento do mercado (Dixit \& Norman, 1980). Segundo essa linha teórica, o protecionismo pode ser mantido de diversas maneiras diferentes, sendo que as mais comuns têm sido por meio das tarifas, subsídios e quotas (Lindert \& Pugel, 1996).

O que se tem como certo, no entanto, é que a economia global vem-se mantendo em estado permanente de mudança à medida que evolui, sendo que o mesmo é esperado de cada economia inserida nesse contexto. A abertura da economia para oportunidades de especialização e para o uso mais eficiente de seus recursos associa-se ao desenvolvimento do comércio internacional à maximização do potencial do país em produzir e adquirir bens. Oponentes do livre comércio argumentam, no entanto, que o comércio internacional ainda mantém ineficiências que prejudicam as nações em desenvolvimento (Hong, 2005).

Essa divergência se expressa de forma ainda mais intensa no contexto de medidas políticas relacionadas à soberania nacional, como é comum no âmbito das exigências de natureza técnica e sanitária. Como os países podem divergir consideravelmente em função de diversos fatores, que incluem desde a preferência e cultura de sua população, até o grau de instrução e capacitação tecnológica, tem sido difícil identificar, a partir da teoria econômica, uma maneira de distinguir uma exigência 
legítima de um requisito não legítimo, quando esse afeta o fluxo de comércio entre os países.

Os acordos multilaterais relacionados a barreiras técnicas (Acordo TBT) e medidas sanitárias e fitossanitárias (Acordo SPS) firmados no âmbito da Organização Mundial do Comércio explicitam, de forma bastante clara, que têm por objetivo permitir que os países mantenham ou introduzam as exigências consideradas necessárias para prover proteção à saúde humana, animal e de plantas, preservando o meio ambiente (Roberts et al., 1999). No entanto, ao mesmo tempo em que facilitam a proteção, esses acordos visam impedir que os países utilizem medidas técnicas e sanitárias com fins protecionistas (Thornsbury, 1999).

Segundo esses mesmos autores, atualmente, considera-se inquestionável que o comércio seja afetado por regulamentações técnicas. O tema já é destacado pela sua importância na literatura de política comercial e na evolução das negociações multilaterais. A regulamentação técnica já se constitui em um aspecto central nas disputas políticas no âmbito internacional. A questão é particularmente importante no caso das negociações que envolvem a agricultura, dada a relevância da regulamentação sanitária e fitossanitária que abrange plantas, animais e a saúde humana, além de questões ambientais. Um dos principais aspectos que diferenciam as barreiras técnicas das barreiras tradicionais, como é o caso das tarifas e quotas, é a natureza indireta de seus efeitos sobre os fluxos de comércio.

Tem-se constatado, por exemplo, que usualmente, as barreiras técnicas se efetivam através de incrementos nos custos incorridos pelos produtores e traders, seja para a adequação às exigências à medida que essas passam a prevalecer, seja em função do impedimento efetivo das importações (Thornsbury, 1999).

No entanto, a quantificação de seus efeitos sobre o comércio particularmente em função dessa natureza diversa em termos de possíveis efeitos divergentes, quando considerados sob a ótica da proteção (técnica ou sanitárias) e do protecionismo implícito às relações comerciais - tem-se constituído em um grande 
desafio para analistas de política comercial (Roberts et al., 1999). De fato, ainda não se dispõe de um procedimento consolidado que possibilite avaliar os custos e benefícios da imposição (bem como da contestação) de regulamentos técnicos que afetam o comércio internacional (Thornsbury et al., 2004). Esses mesmos autores destacam que as estratégias adotadas nas negociações, bem como os estudos que desenvolvem análises com tal objetivo geralmente enfocam problemas específicos a países ou produtos, empregando-se com frequência, a abordagem do estudo de casos.

O presente trabalho segue esse mesma linha de abordagem, assumindo uma característica peculiar, por enfocar um aspecto que pode ter implicações de natureza diversa para a economia, quando analisado sob o ponto de vista de política econômica de bem-estar e sob o ponto de vista da política comercial. Considera-se que a principal contribuição desse novo enfoque analítico é a constituição de uma base de informações requeridas para o desenvolvimento de análises prospectivas quanto à tendência de barreiras técnicas às exportações brasileiras.

Os objetivos da PIF são essencialmente positivos sob o ponto de vista do produtor e do consumidor estrangeiro e possivelmente consumidores doméstico com poder aquisitivo suficiente para adquirir um produto diferenciado. Um aspecto que extrapola os objetivos do presente trabalho, porém já pôde ser identificado pela análise conduzida, é que os benefícios, possívelmente não serão apropriados por todos os participantes do mercado - tanto consumidores como produtores. Parece procedente, ainda, concluir que as análises sobre os impactos desses exigências técnicas, quando afetam o comércio, sejam avaliadas não apenas sob o ponto de vista de seus custos, como é usualmente feito no caso de barreiras convencionais, como também de seus benefícios. 


\section{MATERIAL E MÉTODOS}

\subsection{Dados}

As informações levantadas para a condução da análise proposta para o estudo correspondem às notificações sobre regulamentações apresentadas à $\mathrm{OMC}$, no âmbito do Acordo sobre Medidas Sanitárias e Fitossanitárias (SPS) e do Acordo sobre Barreiras Técnicas ao comércio internacional.

As notificações são instrumentos previstos nesses Acordos para garantir transparência, onde sempre que um governo se propõe a uma nova regulamentação (ou sistema de avaliação de conformidade) ou modifica uma já existente, deve notificar a decisão a OMC, principalmente se esta se diferenciar de um padrão internacional (dado que as exigências não precisam, necessariamente, obedecer ao que é estabelecido por organismos internacionalmente reconhecidos) ou se tiver efeito significativo no comércio mundial.

Uma vez apresentada a $\mathrm{OMC}$, o seu Secretariado torna-se responsável pela divulgação das notificações a todos seus países membros, através dos pontos focais, para que sejam discutidas e comentadas, antes que venham a ser efetivadas.

No presente trabalho, as notificações no âmbito SPS foram obtidas para os Estados Unidos, a partir de documentos do tipo G/SPS/N/USA/875 e para os países da União Européia, tomando os documentos G/SPS/N/EEC/134. A escolha dos países analisados baseou-se na importância destes na importação de frutas brasileiras e por serem pró-ativos na criação de normas e padrões. 
Vale ressaltar que as notificações feitas pelos países da UE a OMC são apresentadas tanto como notificações que se referem ao bloco econômico, como por país individual. No presente estudo, no entanto, consideraram-se apenas as notificações apresentadas pelo bloco econômico, por serem em maior número e para facilitar o tratamento e interpretação dos resultados.

As notificações referentes a barreiras técnicas podem ser obtidas a partir de documentos do tipo G/TBT/N/USA/65 para os Estados Unidos e do tipo G/TBT/N/EEC/65 para o a União Européia (OMC, 2004).

Na descrição de uma notificação, encontram-se itens como o país membro que submete a notificação (país notificador), o organismo responsável pela imposição da exigência, a data da notificação, o código, o(s) produto(s) abrangido(s), a base legal ou portaria, a descrição da medida, a descrição da portaria, país ou região afetada pela notificação, o objetivo, recomendação ou guia internacional, além da explicitação de outros documentos relevantes sobre a norma alvo da notificação.

A denominação desses documentos obedece ao seguinte critério: - a primeira letra identifica a coleção de documentos da $\mathrm{OMC}^{28}$; - seguindo-se a primeira barra temse a identificação da série do documento ${ }^{29}$; - após a segunda barra, tem-se a indicação do tipo de documento ${ }^{30}$; - após a terceira barra indica-se o código ISO do país ${ }^{31}$; - o número final refere-se à numeração do documento ${ }^{32}$. Para a contagem das notificações, não foram levados em consideração os documentos técnicos referentes a addendum e corrigendum, por se constituírem em extensões ou correções nas notificações já emitidas.

\footnotetext{
${ }^{28}$ No caso dos documentos pesquisados, a letra G refere-se à coleção de documentos da OMC, explicitando que essa se refere ao comércio de bens (G: Trade in Goods (1994)).

${ }^{29}$ Classe de documentos que dividem uma estrutura comum. No caso são documentos referentes ao Acordo de Medidas Sanitárias e Fitossanitárias.

${ }^{30}$ Tipo de documento, neste caso "N" abreviação usada para denotar documentos que se dividem em atributos comum, como tipo específico de conteúdo de informação: $\mathrm{N}$ = notificação.

${ }^{31}$ Cada país membro da OMC tem seu código ISO, formado de três caracteres.

${ }^{32}$ Números seqüenciais que indicam a ordem das notificações.
} 
O período considerado para a análise inicia-se em 1995, ano em que os países membros passaram a ser obrigados a notificar mudanças em normas e regulamentos técnicos, sanitários e fitossanitários, conforme estabelecido nos Acordos da OMC, continuando até outubro de 2004.

As notificações sobre medidas sanitárias e fitossanitárias (SPS) e medidas técnicas (TBT) encontram-se disponíveis no site da OMC. Essas podem ser também consultadas junto ao Ponto Focal para o Brasil, que é o INMETRO. Além disso, o Centro de Estudos Avançados em Economia Aplicada (CEPEA) dispõe de um banco de dados organizado para facilitar o cruzamento das informações constantes nas notificações, desenvolvido e mantido pela equipe de Estudos Internacionais.

\subsection{Procedimento}

O procedimento empregado para a análise qualitativa conduzida no presente estudo compreendeu duas etapas principais. Uma primeira que envolveu a identificação de todas as notificações relacionadas a frutas, apresentadas pelos EUA e pelos países da UE à OMC, em conformidade com os Acordos SPS e TBT, durante o período considerado para a análise.

As notificações foram categorizadas por produtos (enfocando-se as frutas) e por objetivos a que se referiam.

Feita essa primeira triagem, foram identificadas algumas peculiaridades que levaram a uma nova seleção das notificações trabalhadas para a análise, restringindo-as a um conjunto indicando as características mais frequentes, em termos de produtos e objetivos. Nessa seleção, identificou-se na descrição das notificações, que essas tratavam, em grande parte, de Limite Máximo de Resíduos (LMR) associados a agroquímicos. Em função disso, optou-se por restringir a análise às notificações com tal referência. 
Embora "frutas" tenha sido a principal categoria de produtos para proceder à seleção das notificações, considerou-se adequado englobar a categoria alimentos, e à categoria pesticidas que apresentavam indicação explícita a frutas, tanto na definição do produto alvo, como no item "Descrição", explícito nas notificações.

A primeira etapa resumiu-se, portanto, na obtenção de uma base selecionada de notificações onde na "Descrição" o objetivo focado fosse: Limite Máximo de Resíduos referentes a frutas.

A segunda etapa consistiu na verificação do conjunto de notificações selecionadas na etapa anterior, quanto à sua consistência com as normas do Codex Alimentarius, organismo internacionalmente reconhecido e por estar em conformidade com Acordos Internacionais TBT e SPS.

Nessa análise verificou-se no item "descrição" das notificações, se as exigências dos países importadores constavam no Codex Alimentarius. As que não constavam foram interpretadas-como novas normas sendo desenvolvidas pelos países. As que constaram, avaliou-se em que medidas essas eram equivalentes, mais ou menos restritivas que as indicadas pela referência internacional.

Porém, sempre que uma exigência do país importador se mostrasse mais restritiva que a norma Codex, considerou-se a possibilidade de que isso se constituísse em uma indicação de que a medida representava uma possível barreira ao comércio, embora não se disponha de argumentos plenos para identificar a medida como não legítima. Por exemplo, para os Estados Unidos encontrou-se em uma das notificações analisadas o pesticida imidacloprid para citrus para morango, onde na notificação constava que era permitido $0.7 \mathrm{ppm}$ e no Codex o mesmo pesticida para a fruta citada estava como permitido $1 \mathrm{mg} / \mathrm{Kg}(1 \mathrm{ppm}=\mathrm{mg} / \mathrm{Kg})$. A partir dessa análise considerou-se, em função do requerido pelos Estados Unidos, que esse país estava sendo mais exigente que o Codex, considerando-o mais restritivo. Em casos em que os Estados Unidos apresentaram em suas normas, valores superiores ao sugerido pelo Codex, em suas notificações, o país foi considerado menos restritivo. 
Para analisar a freqüência relativa desses três casos principais foram compostas as Tabelas 8 e 9 que mostram o número de notificações feitas pelos países importadores, ano a ano, ao longo do período considerado para a análise; ou seja, a partir de janeiro de 1995 até outubro de 2004.

As constatações derivadas dessas etapas preliminares foram utilizadas para avaliar a PIF brasileira, no que se refere à adequação de seus mecanismos e exigências para que a fruta nacional, obtida por pelos produtores que aderem à produção integrada, seja identificada como adequada aos requisitos impostos às importações pelos principais compradores desses produtos no mercado internacional, particularmente no que tange a LMR de pesticidas.

Paralelamente, entre as notificações e o Sistema PIF, é importante ressaltar também o caso de agrotóxicos, onde estes têm sido notificados em quantidades muito significativas em relação a outros produtos. E este pode ser um forte ponto de estrangulamento para o Brasil.

Isto se dá pelo fato de o Brasil possuir clima tropical e estar evoluindo muito na produção de frutas tropicais e nossos maiores importadores são países de clima temperados, com isso estes exigem que os agrotóxicos usados aqui, sejam devidamente registrados em seus países e estejam dentro do limite máximo de resíduos permitidos por eles. Entretanto, muitas vezes os defensivos aqui empregados não são os mesmos usados nos outros países, dada a diferença climática, e , assim sendo, não estão lá registrados. Além do mais, os limites máximos podem variar em função do clima, do solo, causando uma forte incompatibilidade (variabilidade) de objetivos ${ }^{33}$

Os agrotóxicos utilizados pela PIF no Brasil seguem os limites definidos na comissão do Codex Alimentarius, mas existe sério problema para o Brasil no âmbito de exigências de limites máximos de agrotóxicos e agrotóxicos não registrados.

\footnotetext{
${ }^{33}$ BUSCHINELLI, C.; MAGANHOTTO, C.M.; HERMES, L.C., op. cit. p.22.
} 
Pesquisadores da Embrapa meio ambiente estão tentando intervir junto ao governo brasileiro, Ministério da Agricultura Pecuária e Abastecimento e Inmetro, para mostrar a importância do reconhecimento internacional do selo PIF Brasil ${ }^{34}$. A demanda é para que o governo brasileiro interfira nas políticas externas pedindo equivalência e padronização, assegurados nos Acordos Internacionais, tanto TBT quanto SPS, mencionado no Capítulo 3.

Outro forte ponto de estrangulamento do sistema PIF que pode ser relacionado com o alto número de notificações feitas a agroquímicos, é a elevação substancial dos custos de transação para o exportador (Brasil) diante da diversidade de exigências sanitárias e fitossanitárias dos países é uma das dificuldades mais evidentes e demonstra a importância da harmonização e equivalência das medidas SPS, pelo fato dos agroquímicos utilizados no Brasil diferirem dos da UE e EUA (devido a divergência de climas) e por isso sofrem restrições por não serem devidamente registrados e por não estarem dentro do limite máximo de resíduos.

Portanto, no presente estudo, além de constituir uma orientação quanto às tendências das exigências sanitárias e fitossanitárias através das notificações, buscou-se identificar e destacar os principais aspectos do Sistema PIF, de forma a criar um material de referência para análise de adequação da PIF brasileira com as exigências internacionais.

\footnotetext{
${ }^{34}$ BUSCHINELLI, C.; MAGANHOTTO, C.M.; HERMES, L.C., op. cit. p.22.
} 


\section{RESULTADOS E DISCUSSÃO}

Sabe-se que os países em desenvolvimento, por estarem em estágio menos avançado em termos de desenvolvimento tecnológico, apresentam dificuldades em adotar os métodos e processos produtivos exigidos pelos países desenvolvidos. No caso do Brasil, em relação a alguns países menos desenvolvidos que também apresentam vantagem comparativa na produção de frutas, está relativamente bem amparado em termos de pesquisas e desenvolvimento, técnicos formados na área afim, e interesse voluntário do setor privado na fruticultura, em adequar nosso país às exigências do mercado importador e de se atentar aos novos nichos de mercados que estão se formando.

Segundo pesquisadores da Embrapa que estão auxiliando no desenvolvimento das normas PIF no Brasil, frente aos outros mercados (internacionais) o Brasil é o que apresenta as normas mais desenvolvidas e completas para frutas, procurando se adequar às exigências que ainda não atendemos. $\mathrm{A} \mathrm{BRC}$, consórcio varejista inglês já fez uma proposta ao Ministério da Agricultura de comprar somente frutas advindas do Brasil desde que estas estejam com o selo PIF e atentas às exigências européias. Mais uma vez ressaltando a importância de se mostrar a evolução das tendências dos mercados importadores (no caso deste trabalho um modo é pelas notificações).

A evolução das exigências e preocupações fitossanitárias dos maiores importadores de frutas do Brasil são apresentadas neste item de uma forma sistemática, em tabelas, buscando identificar possíveis tendências em termos de medidas e exigências. 


\subsection{Análise das notificações e verificação de possíveis tendências no comercio internacional de frutas}

De maneira geral, observa-se que desde 1995, quando a apresentação das notificações à $\mathrm{OMC}$ tornou-se obrigatória para os países membros, os países desenvolvidos têm participado de forma mais intensa na normatização internacional do que os países em desenvolvimento. Isso permite inferir que os padrões que vêm sendo preconizados em termos sanitários e fitossanitários estão mais associados ao perfil das exigências e necessidades desses países mais ricos.

Na Figura 7, verifica-se análise da proporção das notificações feitas pelos Estados Unidos e países da União Européia, para frutas, em relação ao total de notificações feitas por estes países. No ano de 1998, por exemplo, 18,8\% das notificações totais feitas pelos Estados Unidos referiam-se às frutas. O percentual mais alto foi alcançado em 1999, pela UE, sendo que $25 \%$ do total de notificações apresentadas pelo bloco à $\mathrm{OMC}$ tiveram as frutas como foco principal. 


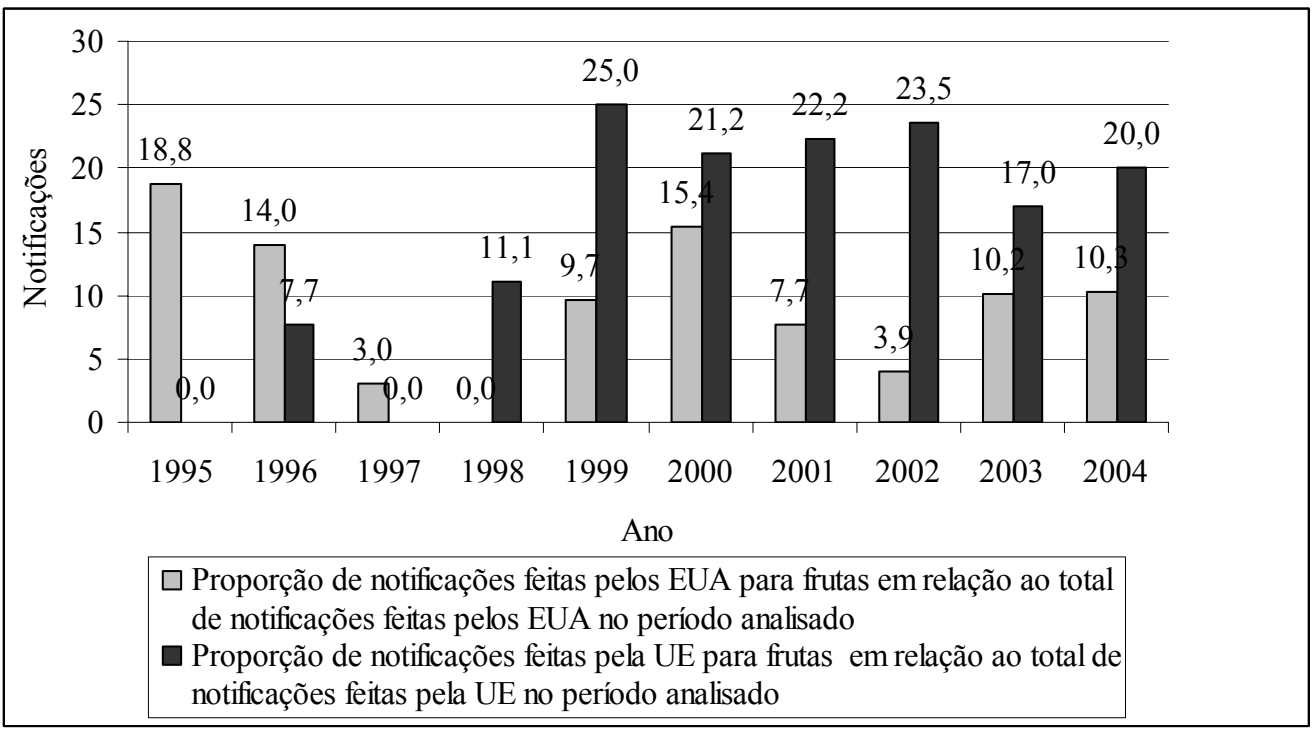

Figura 7 - Evolução anual do percentual das notificações feitas pelos Estados Unidos e União Européia para frutas em relação ao total das notificações feitas por estes países no período de janeiro de 1995 a outubro de 2004

Analisando as notificações na Tabela 8 percebe-se que tanto os Estados Unidos, quanto a União Européia, têm enfatizado questões que envolvem a segurança dos alimentos na sua normatização. Isso é particularmente verdadeiro quando se avaliam as notificações relativas às frutas. Nesse caso, existe um número considerável inserido na categoria produtos e descrição, voltados para agroquímicos, na forma de Limite Máximo de Resíduos (LMR). 
Tabela 8. Número de Notificações SPS apresentadas à OMC pelos Estados Unidos e União Européia, classificadas como: total de notificações; notificações referentes a frutas; notificações referentes a LMR relacionados a frutas. Período: 1995 a outubro de 2004

\begin{tabular}{|c|c|c|c|c|c|c|c|c|}
\hline Ano & $\begin{array}{c}\text { Total de } \\
\text { Notificações } \\
\text { feita pelos } \\
\text { EUA }\end{array}$ & $\begin{array}{l}\text { Notificações } \\
\text { feitas pelos. } \\
\text { EUA relativo } \\
\quad \text { a frutas }\end{array}$ & $\begin{array}{l}\text { Notificações } \\
\text { feitas pelos EUA } \\
\text { referentes a } \\
\text { LMR/frutas }\end{array}$ & $\begin{array}{l}\text { Evolução anual da \% das } \\
\text { notificações de } \\
\text { LMR/frutas no total de } \\
\text { notificações. dos EUA } \\
\text { feitas para frutas }\end{array}$ & $\begin{array}{c}\text { Total de } \\
\text { Notificações } \\
\text { feitas pela UE }\end{array}$ & $\begin{array}{l}\text { Notificações } \\
\text { feitas pela UE } \\
\text { relativas a frutas }\end{array}$ & $\begin{array}{l}\text { Notificações } \\
\text { feitas pela. UE } \\
\text { referentes a } \\
\text { LMR/frutas }\end{array}$ & $\begin{array}{l}\text { Evolução anual da \% das } \\
\text { notificações .de } \\
\text { LMR/frutas no total de } \\
\text { notificações. da UE feitas } \\
\text { para frutas }\end{array}$ \\
\hline 1995 & 16 & 3 & 3 & 100,0 & 23 & & - & 0 \\
\hline 1996 & 50 & 7 & 7 & 100,0 & 13 & 1 & - & 0 \\
\hline 1997 & 33 & 1 & 1 & 100,0 & 12 & & - & 0 \\
\hline 1998 & 35 & & & 0,00 & 18 & 2 & - & 0 \\
\hline 1999 & 62 & 6 & 6 & 100,0 & 8 & 2 & 2 & 100,0 \\
\hline 2000 & 162 & 25 & 25 & 100,0 & 33 & 7 & 7 & 100,0 \\
\hline 2001 & 156 & 12 & 9 & 75,0 & 36 & 8 & 8 & 100,0 \\
\hline 2002 & 127 & 5 & 5 & 100,0 & 34 & 8 & 8 & 100,0 \\
\hline 2003 & 187 & 19 & 19 & 100,0 & 47 & 8 & 8 & 100,0 \\
\hline 2004 & 156 & 16 & 15 & 93,75 & 20 & 4 & 4 & 100,0 \\
\hline TOTAL & 984 & 92 & 90 & 97,83 & 244 & 40 & 37 & 92,50 \\
\hline
\end{tabular}

Fonte: com base em documentos G/SPS/N/USA e G/SPS/N/EEC da OMC (2004) 
Verifica-se que de um total de 984 notificações feitas pelos Estados Unidos no período analisado (1995 a outubro de 2004) 92 notificações foram referentes a frutas, ou seja, 9.34\% das notificações totais e destas 92, 90 notificações se referiam a LMR relacionados a frutas $(97,83 \%$ das notificações para frutas eram em relação a LMR).

Para a União Européia, de um total de 244 notificações feitas no período analisado, 40 foram referentes a frutas, ou seja, 16,39\% das notificações totais, sendo que destas 40 referentes a frutas, 37 se relacionavam a LMR $(92,50 \%)$.

Podendo ressaltar assim a importância do LMR dentro da categoria frutas. No caso dos EUA, os únicos anos em que essas notificações não representam a totalidade, foram 1998, 2001 e 2004. Para a União Européia nos quatro primeiros anos, 1995 a 1998, não foram identificadas notificações sobre LMR aplicado a frutas, Após esse período, no entanto, essa preocupação foi prevalecente para as notificações relacionadas a frutas.

\subsection{Análise da equivalência entre as normas e regulamentos das notificações e as normas do Codex Alimentarius}

Após a coleta e organização das notificações relativas a frutas e LMR, desenvolveu-se uma análise que procurou verificar a adequação das exigências dos países importadores em relação às medidas existentes no Codex Alimentarius a partir do seguinte procedimento:

1) Condução de uma análise das notificações no item "Descrição", onde se buscou identificar, dentro de uma mesma notificação, quais os pesticidas mencionados, quais as frutas (frutas relacionadas aos pesticidas citados) mencionadas, e qual a quantidade dos vários pesticidas, permitida pelos Estados Unidos e União Européia, para a fruta; 
2) Verificação da conformidade entre as exigências mostradas na notificação e as diretrizes indicadas pelo Codex Alimentarius, atualizado em setembro de $1999^{35}$;

3) Trabalhou-se com informação atualizada sobre requisitos do Codex Alimentarius nos EUA, obtida pela representação brasileira do $\operatorname{Codex}^{36}$. Essas informações constam de documentos ainda não disponíveis no site do Codex, mas que já passaram em reuniões da OMC. Esses documentos mostram as quantidades permitidas para pesticidas determinados, de acordo com a fruta. Tais documentos se apresentam com os nomes: ALINORM 01/24 (verificando de modo especial os Apêndices II, III e VI) referente ao ano de 2001; ALINORMM 01/24 A (verificando de modo especial os Apêndices II, III, VI), ano 2001; ALINORM 03/24 (de modo especial os apêndices II e IV) ano de 2003; ALINORM 03/24 A (de modo especial os apêndices III, IV, IV) ano 2003; ALINORM 04/27/24 (de modo especial os Apêndices II, III, V), ano 2004;

4) Todas as notificações foram verificadas individualmente, sendo que as exigências encontradas nas notificações foram conferidas com as normas estabelecidas pelo Codex Alimentarius, primeiramente pelo cruzamento dos dados disponíveis no site (atualizado em setembro/1999). Aquelas que não constavam no site do Codex foram pesquisadas nos cinco documentos referentes ao Codex. Tal procedimento pode ser verificado na Tabela 9 e com um maior riqueza dos detalhes no Anexo A.

Na Tabela 9 encontra-se o resultado da avaliação das notificações feitas pelos EUA em relação à sua conformidade com o Codex Alimentarius, seguindo o procedimento:

\footnotetext{
${ }^{35}$ Tal verificação pode ser adquirida através de um cruzamento de dados: frutas e pesticidas; disponível no site do Codex Alimentarius e/ou no site da FAO (www.codexalimentarius.net/web/index_en.jsp e/ou www.faostat.fao.org./faostat). Através do resultado do cruzamento dos dados conseguimos ter acesso a medida permitida pelo Codex Alimentarius de Limite Máximo de Resíduos de um certo pesticida, permitido na produção de uma certa fruta, informando também se tal pesticida ou frutas consta ou não no Codex.

${ }^{36}$ Coordenadora chefe Maria Aparecida Martinelli.
} 
1) Analisando notificação por notificação, buscou-se diferenciar os pesticidas incluídos no item LMR que constam (c) dos que não consta (nc) nas normas do Codex Alimentarius;

2) Nos casos em que o produto "constava" buscou-se verificar se a exigência era mais restritiva ou menos restritiva (em termos de valores máximos permitidos) que a norma estabelecida pelo Codex;

Notou-se que as exigências dos EUA diferem das estabelecidas pelo Codex na unidade de medida. Nos EUA, a unidade encontrada foi PPM (parte por milhão), enquanto no Codex, a unidade é apresentada em $\mathrm{mg} / \mathrm{kg}$ (miligramas do pesticida por quiilograma da fruta). Através da representação do Codex no Brasil identificou-se que 1 $\mathrm{mg} / \mathrm{kg}=1$ PPM. Já para a UE, a unidade estava de acordo com a do Codex (exemplo 0,5 $\mathrm{mg} / \mathrm{kg}$ tanto na notificação, quanto nas normas do Codex Alimentarius).

\subsection{Análise da equivalência entre as normas e regulamentos das notificações e as normas do Codex Alimentarius para os Estados Unidos}

Na tabela 9 verificam-se as informações obtidas para os Estados Unidos, onde de um total de 90 notificações pode-se observar que a maioria não constava no Codex Alimentarius. Das notificações que estavam de acordo com o organismo internacional, verifica-se que o ano de 2000 foi o que mais esteve dentro das referências, onde das 19 notificações encontradas para frutas neste ano, sete constavam no codex, porém dentre as sete notificações em quatro verificou-se uma maior restritividade dos EUA. Verificou-se também que para os Estado Unidos dentro de uma mesma notificação conseguiu-se extrair informações mais detalhadas sobre as normas referentes a frutas como: se estas constavam ou não no codex; se estavam mais ou menos restritivas; se existiam os pesticidas para as frutas notificadas ou para outras frutas; se havia sido revogado ou não. 
Tabela 9. Número de notificações de LMR para os Estados Unidos

\begin{tabular}{llll}
\hline \multicolumn{1}{c}{ Ano } & $\begin{array}{c}\text { Numero de } \\
\text { notificações }\end{array}$ & \multicolumn{1}{c}{$\begin{array}{c}\text { Não consta (no } \\
\text { Codex Alimentarius) }\end{array}$} & \multicolumn{1}{c}{$\begin{array}{c}\text { Consta (no Codex } \\
\text { Alimentarius) }\end{array}$} \\
\hline 1995 & 3 & 1 & $3\left(1^{\mathrm{d}}, 1^{\mathrm{e}}\right)$ \\
1996 & 7 & 4 & $3\left(2^{\mathrm{a}}\right)$ \\
1997 & 1 & 1 & \\
1998 & - & - & - \\
1999 & 6 & 3 & $3\left(1^{\mathrm{d}}, 2^{\mathrm{a}}\right)$ \\
2000 & 25 & 18 & $7\left(4^{\mathrm{c}}, 1^{\mathrm{d}}, 1^{\mathrm{e}}, 1^{\mathrm{a}}\right)$ \\
2001 & 9 & 6 & $3\left(1^{\mathrm{d}}, 1^{\mathrm{a}}\right)$ \\
2002 & 5 & 2 & $3\left(1^{\mathrm{d}}\right)$ \\
2003 & 19 & 14 & $5\left(2^{\mathrm{c}} 2^{\mathrm{a}}\right)$ \\
2004 & 15 & 11 & $4\left(1^{\mathrm{c}}, 3^{\mathrm{a}}\right)$ \\
Total & 92 & 60 & 32 \\
\hline
\end{tabular}

${ }^{a}$ Consta para outras frutas

${ }^{\mathrm{b}}$ Consta e está de acordo com o estabelecido pelo Codex

${ }^{c}$ Mais restritivo que o estabelecido pelo Codex

${ }^{\mathrm{d}}$ Consta e é menos restritivo que o estabelecido pelo Codex

${ }^{\mathrm{e}}$ Foi revogado pelo Codex

Na Figura 8 verifica-se a evolução das notificações feitas a cada ano pelos EUA, dentro dos itens selecionados na tabela como: total de notificações feitas a por ano (1995 a outubro de 2004); quantas estão de acordo com as normas do Codex Alimentarius observada no item "Consta" e quantas não estão de acordo com Codex Alimentarius observada no item "Não consta". 


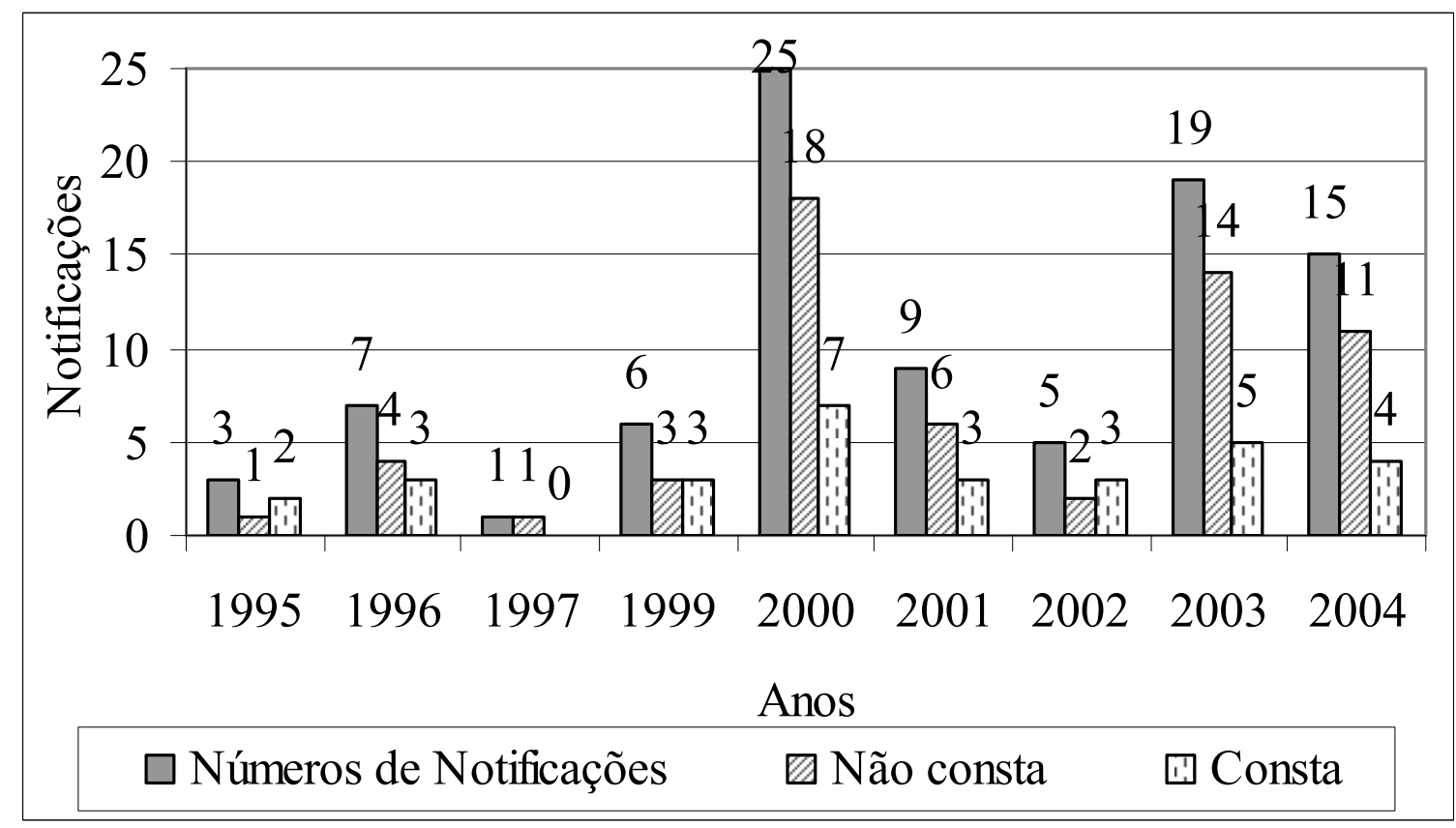

Figura 8 - Comparativo das notificações sobre frutas e produtos alimentícios com objetivo: número de notificações feitas pelos Estados Unidos verificando-se quais constam no Codex e quais não constam no Codex, no período de 1995 a outubro de 2004

Verifica-se que em praticamente todos os anos analisados, o número de informações que não constavam no Codex Alimentarius, superou o número total das que constavam. Esse padrão tornou-se mais visível a partir de 2000, quando a primeira categoria superou a segunda em mais de $50 \%$ um padrão semelhante foi observado em 2003.

Observa-se também que de um total de 90 notificações feitas pelos Estados Unidos para frutas e LMR no período de 1995 a outubro de 2004, somente 35,5\% (32 notificações) estão de acordo com o Codex Alimentarius e a maior parte, $68,8 \%$ (60 notificações), como verificado na tabela 9, não constam. Podendo dizer que os Estados Unidos estão realmente pró-ativos na criação de novas normas para o assunto segurança do alimento. 


\subsection{Análise da equivalência entre as normas e regulamentos das notificações e as normas do Codex Alimentarius para a União Européia}

O perfil da União Européia, nesse âmbito, difere dos Estados Unidos. Embora a unidade de medida da UE tenha se mostrado de acordo com a do codex em termos de unidade de medida $(\mathrm{mg} / \mathrm{kg})$, suas notificações não explicitavam volumes identificando-se apenas se o pesticida era ou não permitido, pelo codex, para na descrição das exigências feitas pelo bloco econômico. Isso dificultou a avaliação da restritividade relativa dos países da UE com relação ao Codex, de maneira semelhante à verificação para os EUA. Procedeu-se à composição de uma tabela diferenciada, onde os itens avaliados foram se as notificações feitas pela UE constavam ou não no Codex Alimentarius.

Um outro aspecto observado foi que, dentro de uma única notificação, ocorre a referência a diferentes pesticidas para frutas específicas ou para frutas no geral. Assim sendo, numa mesma notificação observa-se que alguns pesticidas constam no Codex e outros não, conforme indicado na Tabela 10 e com uma riqueza maior de detalhes no anexo A. (por exemplo, em uma notificação do ano de 2001 constam os pesticidas pymentrozine, azoxystrobin e Krezoxin para frutas em geral, e no Codex consta somente o Kresoxim para frutas em geral). $\mathrm{Na}$ Tabela 10 são apresentadas as notificações de LMR para frutas feitas pela UE.

É importante ressaltar, ainda, que embora o período da análise compreenda 1995 a outubro de 2004 também para a UE, os resultados apresentados a seguir referem-se aos anos posteriores a 1999, uma vez que até esse ano, não se observou notificação referente a LMR para frutas feitas pelo bloco econômico, conforme destacado anteriormente. 
Tabela 10. Notificações de LMR referente a frutas apresentados à $\mathrm{OMC}$ pela União Européia; período: 1999 a outubro de 2004

\begin{tabular}{lllll}
\hline Ano & Numero de notificações & Não consta & Consta \\
\hline 1999 & 2 & 1 & 1 \\
2000 & 7 & 5 & 2 \\
2001 & 9 & 6 & 3 \\
2002 & 8 & 5 & 3 \\
2003 & 8 & 8 & - \\
2004 & 4 & 2 & 2 \\
Total & 38 & 27 & 11 \\
\hline
\end{tabular}

Na Figura 9 verifica-se a evolução das notificações feitas pela UE, anualmente dentro dos itens selecionados na tabela como: total de notificações feitas a por ano (1995 a outubro de 2004); quantas estão de acordo com as normas do Codex Alimentarius observada no item "consta" e quantas não estão de acordo com Codex Alimentarius observado no item "não consta". 


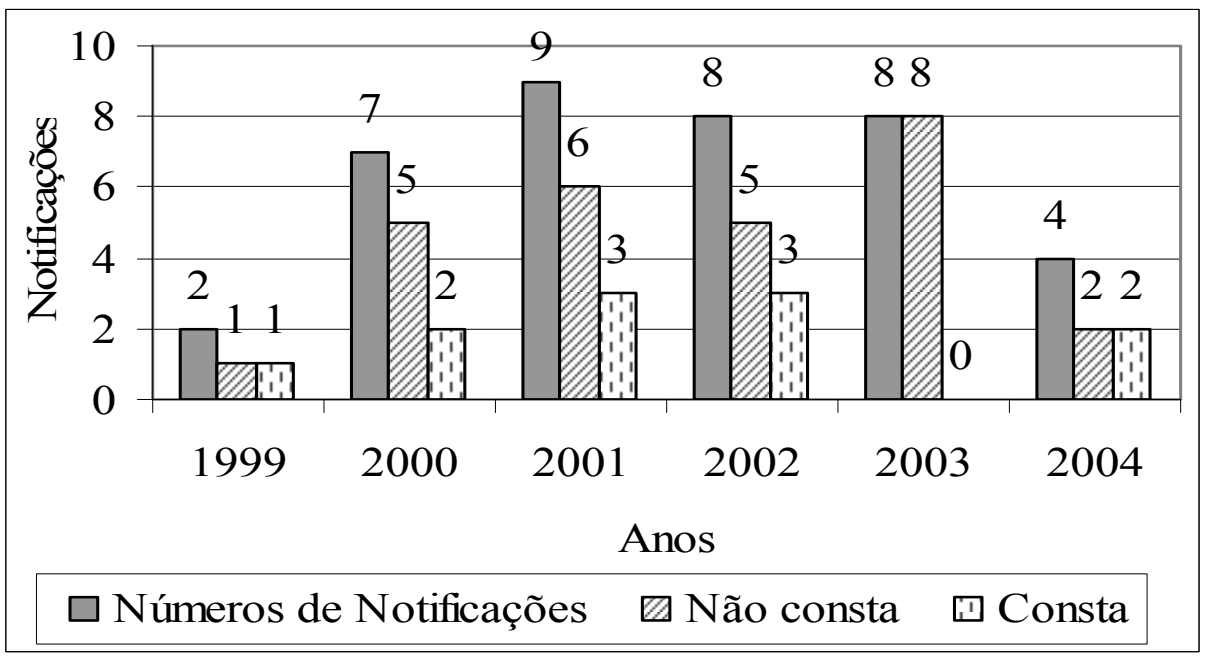

Figura 9 - Número de notificações feitas pela União Européia, referentes a frutas e LMR, diferenciadas quanto à observação das que constam no Codex e daquelas que não constam. Período: 1995 a outubro de 2004

Para a União Européia pode-se verificar uma tendência de normatização semelhante a dos Estados Unidos. Praticamente todos os anos analisados, o número de informações que não constavam no Codex, superaram o número total das que constavam, principalmente no ano de 2003 onde não há registro de notificações que contem no codex no ano de 2001 e 2002 foram os anos que apresentaram uma quantidade maior de notificações que contaram no codex, mostrando uma afinidade da UE com as diretrizes do Codex em relação aos outros anos. Apesar das notificações começarem a ser feitas em 1995, na UE para LMR referentes a frutas, só se percebe uma participação no ano de 1999, pois antes não há registro de notificações feitas pela União Européia sobre o assunto. Nos anos de 2000, 2001 e 2003, uma forte tendência para uma participação pró-ativa da UE para a normatização internacional, devido ao fato das notificações que não constavam no codex superarem as que constavam, principalmente no ano de 2003, onde tal observação se fortifica. 
Pode-se verificar através da Tabela 10, que de um total de 40 notificações feitas pela União Européia para frutas e LMR no período de 1995 a outubro de 2004, somente $29 \%$ das notificações de todo o período analisado (11 notificações) estão de acordo com o Codex Alimentarius e a maior parte, 71\% (27 notificações) não constam. Confirmando a afirmação acima de que a União Européia está se tornado pró-ativa na criação de novas normas relacionadas à segurança do alimento.

No entanto, como o mercado europeu importa maior volume de frutas que os EUA, a PIF mostra uma maior aderência às exigências européias. Isso não significa, no entanto, que os produtores brasileiros que aderem a PIF não se preocupem com as exigências norte-americanas. Por exemplo, um mesmo produtor brasileiro de frutas, pode atender aos dois mercados (europeu e norte-americano), observando, no entanto, que os EUA são mais exigentes tanto no processo produtivo quanto na fase póscolheita $^{37}$.

Para atender, no entanto, os dois maiores mercados importadores, no processo produtivo (principalmente o pós-colheita), torna-se necessário proceder a uma separação da fruta em lotes, sendo que o lote destinado aos EUA, será preparado de acordo com as exigências americanas. O lote destinado à Europa será preparado para atender às exigências européias, segundo informações de técnicos da Embrapa - Meio Ambiente e Semi-Árido que estão trabalhando de modo efetivo na produção de manga e uva do sistema PIF $^{38}$.

Além da constatação acima, encontra-se disponível nas normas do $\operatorname{Codex}^{39}$, as exigências para frutas no processo produtivo e no pós-colheita, sendo estas, mais um fator que demonstra a maior exigência (restritividade) dos EUA em relação à UE. Por exemplo para a fruta manga, os EUA exigem que a fruta esteja 50\% vermelha enquanto a UE exige $25 \%$. Outras exigências como: aparência da fruta, em relação a queimaduras

\footnotetext{
${ }^{37}$ De acordo com na análise das notificações assim como informações obtidas através de entrevistas com técnicos da Embrapa e certificadoras, como a Checkplant e BVQI.

${ }^{38}$ BUSCHINELLI, C.; MAGANHOTTO, C.M.; HERMES, L.C., op. cit., p.22.

${ }^{39}$ CODEX ALIMENTARIUS. Official standards. http://www.codexalimentarius.net (28 Jan. 2005)
} 
de sol, machucaduras e estética e outros detalhes como a forma de embalagem, rotulagem, transporte da fruta, confirma a maior exigência dos EUA". 


\section{CONCLUSÕES}

$\mathrm{O}$ aumento das exigências dos consumidores europeus e norte americano quanto à segurança do alimento conduziram a mudanças no ambiente institucional e organizacional no Brasil, dado que a UE e os EUA são os principais importadores de frutas brasileiras. Dentre tais mudanças, destacou-se de modo significativo a implementação da Produção Integrada de Frutas (PIF) no Brasil.

Diante do crescimento do comércio internacional de alimentos, as frutas defrontam-se com barreiras fitossanitárias que tendem a se fortalecer com o aumento da conscientização dos consumidores em relação à qualidade e inocuidade da fruta e a preocupação dos países em proteger seu território contra possíveis ameaças de doenças para suas plantas e animais.

A partir do instrumento de transparência do Acordo SPS/OMC - as notificações, que indicam a regulamentação dos países - constatou-se que as frutas são produtos bastante afetados por medidas fitossanitárias notificadas, sugerindo que as normas e regulamentos referentes à segurança do alimento, saúde do consumidor, produção e comercialização de frutas, têm-se tornado bastante significativas, particularmente nos países estudados. Isso pode ser verificado pela análise das notificações SPS dos Estados Unidos, que de 1995 a 2004, tiveram 9,34\% referentes a frutas. Dentre essas, 97,83\% eram relacionadas a Limites Máximos de Resíduos (LMR). No caso da União Européia, 16,39\% das notificações totais feitas pelos países à OMC, contém medidas relacionadas a frutas e destas, 92,5\% referentes a LMR. As justificativas mais freqüentes para as exigências apresentadas pelos maiores importadores foram: a segurança do alimento; segurança da planta; segurança do consumidor. 
Conclui-se que, adotando-se a análise das notificações como indicadora de tendências, um grande número de medidas visou restringir ainda mais a entrada e saída dos produtos. Parte significativa dessas medidas enfatiza a reação dos consumidores de não adquirir um produto importado não certificado e a criação dos novos regulamentos fitossanitários. Para a comercialização de frutas, esses novos regulamentos dos países desenvolvidos relacionam-se, em grande parte, a LMR para agroquímicos.

Conforme discutido, as diretrizes da PIF brasileira vêm sendo moldadas em programas de natureza semelhante aos desenvolvidos nos países ricos, principalmente nos países europeus, visando a obtenção de produtos que atendam às novas exigências dos consumidores, não apenas em termos de sabor e preços competitivos, mas também a requisitos atestados de sanidade e preservação das condições ambientais. A análise sobre o Programa PIF no Brasil, no presente estudo, permitiu concluir que o seu desenvolvimento vem sendo direcionado, fundamentalmente, para atender às exigências do mercado externo, visando o aumento da fatia de mercado e divisas, estimulando os produtores a adotarem práticas de cultivo que atendam às exigências dos consumidores estrangeiros. Assim um produto certificado, com selo PIF, promoveria a diferenciação necessária para as frutas brasileiras nos principais mercados importadores.

Dado que a UE importa $65 \%$ das frutas nacionais e os EUA aproximadamente $10 \%$, e assumindo que as notificações sejam uma variável proxy, adotada neste trabalho, para analisar a evolução do desenvolvimento e internacionalização dos padrões e normas, considera-se de grande relevância que o Programa PIF do Brasil tenha como foco as tendências futuras, direcionadas pelas notificações analisadas, com destaque aos agroquímicos para frutas. Isso é reforçado pelo fato desses países desempenharem importante papel na normalização internacional.

Tendo-se averiguado a evolução das notificações feitas pelos países desenvolvidos importadores, e conseqüentemente sua maior participação na normatização internacional, impõe-se aos países em desenvolvimento, no caso o Brasil, a adoção de regras, normas, procedimentos vinculados às suas exigências. 
O acesso à informação pode ser interpretado como um novo insumo, , sendo que alguns segmentos ficarão ainda mais dispersos se considerarmos os desafios à extensão rural, cuja eficiência pode ser reduzida por políticas públicas que concentrem permanentemente a informação e as tecnologias apenas nos agentes de maior poder econômico. Assim, como resultado desse processo de integração entre os mercados, pode ocorrer a exclusão de produtores agrícolas e países com menor renda com maiores dificuldades para adequação às exigências do mercado que se torna cada vez mais competitivo, seja por insuficiência de renda ou por impossibilidade de aumentarem um acréscimo nas margens de trabalho, ou de risco econômico e maior dificuldade ao acesso às informações.

Diante disso, parece prevalecer uma visão simplista que supõe a adoção dessas normas pelos países em desenvolvimento, arcando não só com os custos adicionais que podem acarretar ao setor privado, mas também com o ônus comercial do período de adequação. Além disso, embora os países afetados possam buscar o reconhecer a equivalência de seus padrões e procedimentos, trata-se de um processo que exige recursos financeiros. A comprovação nos fóruns competentes pode se tornar um processo moroso, o que acarreta ônus adicionais.

No contexto teórico, é interessante observar que a teoria do comércio internacional preconiza que a evolução das relações de trocas entre os países implica em ganhos de bem estar econômico, ou seja, qualquer tentativa de dificultar o livre comércio internacional resulta em uma redução dos ganhos potenciais para o país. Parece plausível considerar, no entanto, que se os custos da regulamentação são acompanhados de ganhos de eficiência suficientemente elevados para compensar as perdas, podem ser considerados como investimentos feitos pela sociedade para atingir uma regulamentação benéfica.

Os fundamentos da Teoria Econômica discutidos neste trabalho sugerem que os indivíduos de uma economia podem ser, de fato, beneficiados pelo estabelecimento e desenvolvimento do comércio global. Nesse contexto, espera-se que a abertura da 
economia para oportunidades de especialização e para o uso mais eficiente de seus recursos pelo comércio internacional, leve à maximização do potencial do país em produzir e adquirir bens.

Dessa forma, se cada país se especializar e comercializar os bens para os quais detém maior eficiência produtiva, ou seja, sempre que o custo de oportunidade da produção de todos os bens, superar o custo da especialização, haverá um ganho para o país. Considera-se que esse é o caso da produção de frutas no Brasil, onde os benefícios resultantes da adequação do setor para possibilitar a maior inserção internacional incluem: ganho sociais com o aumento de emprego; ganhos com o aumento de divisas; ganhos ambientais com a redução de defensivos agrícolas; além dos ganhos para o produtor, e também consumidor, como citados no capitulo 3.

No presente estudo foi mencionado que se pode considerar alguns padrões voluntários, como a adesão dos produtores ao programa PIF, e também praticamente todas as regulamentações mandatórias visam solucionar falhas de mercado, podendo-se aproximar do conceito bens públicos. Exemplos de iniciativas dessa natureza incluem a proteção ambiental, o saneamento público, segurança do trabalhador e uma gama de aspectos de sanidade e saúde de plantas, animais e seres humanos.

A análise da PIF permite concluir que seus objetivos são essencialmente positivos sob o ponto de vista do produtor e do consumidor estrangeiro e, possivelmente, também para o consumidor doméstico com poder aquisitivo suficiente para adquirir um produto diferenciado.

Parece procedente, ainda, concluir que as análises sobre os impactos das exigências fitossanitárias, quando afetam o comércio, sejam avaliadas não apenas sob o ponto de vista de seus custos, como é usualmente feito no caso de barreiras convencionais, como também de seus benefícios.

Esse é um fator que merece atenção do sistema PIF no Brasil, onde a adesão dos produtores brasileiros de frutas, ao sistema e o rápido reconhecimento internacional 
do selo PIF Brasil pode vir a facilitar ou proporcionar maior abertura ao mercado europeu e principalmente o norte-americano, fazendo com que o Brasil consiga uma maior inserção no mercado internacional, de modo competitivo, incrementando sua fatia de mercado.

Para tal, a análise conduzida permite concluir que os esforços nacionais devam voltar-se não só para um maior conhecimento e melhor entendimento dos acordos internacionais, como também para o conhecimento das necessidades reais das pessoas nos países importadores. Sobretudo, é preciso organizar e ajustar o país em termos de estrutura doméstica, particularmente, quanto à defesa sanitária. e fitossanitária. É necessário demonstrar que os sistemas de defesa sanitária e fitossanitários do país são eficientes e eficazes. $\mathrm{Na}$ seqüência, e não menos importante, é preciso trabalhar pela promoção comercial e pelo marketing internacional, de forma a aproximar-se dos consumidores no exterior e criar a confiança necessária para consolidar o Brasil como grande exportador de frutas seguras e de qualidade.

A partir disso, torna-se importante a divulgação do Programa de Produção Integrada de Frutas do Brasil, para que haja uma maior adesão de produtores de frutas, um maior incentivo e preocupação do governo brasileiro e um maior empenho para o rápido reconhecimento do selo desse programa nos mercados importadores. Isso é particularmente importante, tendo em vista que as estimativas mostradas no corpo do presente trabalho, indicam o potencial do país em tornar-se o maior produtor mundial de frutas no final desta década.

É importante destacar que a evolução temporal da PIF pode ser afetada por uma série de fatores, como o perfil das equipes técnicas que compõem os órgãos responsáveis pela normalização, disponibilidades de recursos, problemas técnicos conjunturais que podem surgir repentinamente em função da demanda de algum setor ou de alguma disputa com outros países, e que podem gerar a necessidade da normalização. Portanto, os resultados do presente trabalho devem ser interpretados como uma análise apenas descritiva, requerendo, para interpretar a sua maior ou menor gravidade ou abrangência, um estudo caso a caso. 
É interessante observar, no entanto, que os ganhos decorrentes da qualidade serão refletidos no preço final do produto, uma vez que o maior aproveitamento da matéria prima implica em menores custos envolvidos na sua seleção, separação e na vida útil do produto na prateleira. Entretanto, para viabilizar essas expectativas o Brasil precisa investir em qualidade, que quando comparada aos padrões utilizados por outros países mais desenvolvidos, não tornam nossos produtos competitivos.

Verifica-se, portanto, que o reconhecimento das características de "qualidade e certificação" para a fruta brasileira, requer um maior empenho para a obtenção de um selo ao rótulo do produto comercializado. Isso requer uma mudança de hábitos e posturas de fornecedores, produtores, atacadistas, exportadores, consumidores e, principalmente governamentais.

Para que a implantação desses processos no país surta o efeito esperado é imprescindível o apoio governamental na qualidade de serviços e incremento a pesquisas básica e aplicada que enfoquem: fiscalização fitossanitária efetiva e constante; incentivo a pesquisa agropecuária para a busca e disponibilização de sistemas de produção mais avançados, menos agressivos ao meio ambiente e competitivo internacionalmente, assim como de boas práticas agrícolas de manejo; oportunidades para que o produtor eleve seu nível de investimentos na propriedade (tecnificação); capacitação de profissionais envolvidos em toda a cadeia produtiva (onde se incluem os alfandegários); diminuição de perdas; incentivo a conscientização e percepção gerais através de educação agroambiental aplicada ao homem do campo e a difusores; disponibilidade de acesso a meios de informação constantes e atualizados; melhoria no processo de transporte da fruta das propriedades para as unidades de processamento; modificação de padrões de automação de produção, entre outros.

$\mathrm{O}$ aprendizado dessa nova maneira de pensar e fazer agricultura passa por experiências de êxito e fracasso. Portanto, é razoável considerar que em países em desenvolvimento, como o Brasil, o desafio da produção de alimentos em sistemas agroecológicos, dentro de uma economia globalizada e flexível, implica na retomada do 
debate sobre políticas públicas amplas e diferenciadas, reforma agrária, agricultura familiar e segurança alimentar. Fica claro, porém, que apesar de não ser pequeno, é imprescindível o esforço de toda sociedade para uma mudança de paradigma da pesquisa agrícola, principalmente, quando esta se encontra atrelada a alterações sócio-políticas de caráter estrutural. 
ANEXOS 
ANEXO A - Análise das notificações de LMR

\begin{tabular}{|c|c|c|c|c|c|c|}
\hline & & Pesticida & Frutas & Notif & \multicolumn{2}{|c|}{ Codex } \\
\hline & & & & & Consta & Não Consta \\
\hline 1999 & 1 & azoxystrobin & & & & + \\
\hline \multirow{18}{*}{2000} & \multirow{3}{*}{1} & vinclozolin & tomate & & & \\
\hline & & \multirow[b]{2}{*}{ diphenylamine } & apple & & & + \\
\hline & & & pears & & & + \\
\hline & 2 & spiroxamine & fruits & & & + \\
\hline & \multirow{2}{*}{3} & \multirow{2}{*}{ mercury } & fruits & & & + \\
\hline & & & berries & & & + \\
\hline & & $\begin{array}{c}\text { nitrato } \\
\text { (contaminantes) }\end{array}$ & fruits & & & + \\
\hline & 4 & aflotoxins & fruits & & & + \\
\hline & 5 & Kresoxim-methyl & fruits & & + & \\
\hline & \multirow{8}{*}{6} & aziphos ethyl & \multirow{8}{*}{ fruits } & & foi revogado & \\
\hline & & chlozolinate & & & & + \\
\hline & & dinoterb & & & & + \\
\hline & & DNCO & & & & + \\
\hline & & monolinuros & & & & + \\
\hline & & propham & & & foi revogado & \\
\hline & & pyrazophos & & & & + \\
\hline & & tecnazene & & & + & \\
\hline & 7 & azoxystrobin & fruits & & & + \\
\hline \multirow{15}{*}{2001} & 1 & fluroxypir & fruits & & & + \\
\hline & \multirow{3}{*}{2} & azoxystrobine & & & & + \\
\hline & & \multirow[b]{2}{*}{ Krezoxim } & citurs & & + & \\
\hline & & & fruits & & + & \\
\hline & 3 & Cholorothalon & fruits & & + & \\
\hline & \multirow[b]{2}{*}{4} & dioxins & fruits & & & + \\
\hline & & poly chlorinated & fruits & & & + \\
\hline & \multirow[b]{2}{*}{5} & dioxins & & & & + \\
\hline & & polychlrinated & & & & + \\
\hline & \multirow[b]{2}{*}{6} & dioxins & fruits & & & + \\
\hline & & polychlrinated & fruits & & & + \\
\hline & $7 * *$ & $\mathrm{n}$ - pesticidas** & $\mathrm{n}$-frutas** & & & \\
\hline & \multirow[b]{3}{*}{8} & pymetrozine & fruits & & & + \\
\hline & & azoxystrobin & fruits & & & + \\
\hline & & Krezoxim & fruits & & $*$ & \\
\hline
\end{tabular}


ANEXO A - Análise das notificações de LMR

\begin{tabular}{|c|c|c|c|c|c|c|}
\hline & & Pesticida & Frutas & Notif & \multicolumn{2}{|c|}{ Codex } \\
\hline & & & & & Consta & Não Consta \\
\hline & 9 & pymetrozine & & & & + \\
\hline \multirow{14}{*}{2002} & & bentazone & & & & + \\
\hline & 1 & pyridate & & & & + \\
\hline & & lindane & \multirow[b]{4}{*}{ fruits } & & + & \\
\hline & & quintozine & & & + & \\
\hline & & permethrin & & & + & \\
\hline & 2 & parathion & & & + & \\
\hline & & dimethoate & fruits & & + & \\
\hline & 3 & $\begin{array}{l}\text { oxydementon - } \\
\text { methyl }\end{array}$ & & & foi revogado & \\
\hline & 4 & somente cita LMR & & & & \\
\hline & 5 & somente cita LMR & & & & \\
\hline & $6 * *$ & & & & & \\
\hline & & triasulfuron & fruits & & & + \\
\hline & 7 & thifensulfuron & fruits & & & + \\
\hline & 8 & azoxystrobin & & & & + \\
\hline \multirow{13}{*}{2003} & $1 * *$ & & & & & \\
\hline & 2 & $\begin{array}{c}\text { cita como evitar } \\
\text { combinação de certos } \\
\text { pesticidas }\end{array}$ & & & & \\
\hline & & acephate & fruits & & & + \\
\hline & & metalaxyl & fruits & & & + \\
\hline & 3 & parathion & fruits & & & + \\
\hline & \multirow[b]{5}{*}{4} & chlormequat & \multirow[b]{5}{*}{ fruits } & & & + \\
\hline & & fenamiphos & & & & + \\
\hline & & lambda-cyhalothrin & & & & + \\
\hline & & Kresoxin - methyl & & & & + \\
\hline & & azoxystrobin & & & + & \\
\hline & $5 * *$ & & & & & \\
\hline & $6 * *$ & & & & & \\
\hline & 7 & $\begin{array}{c}\text { somente cita a } \\
\text { necessidade de LMR }\end{array}$ & & & & \\
\hline
\end{tabular}


ANEXO A - Análise das notificações de LMR

\begin{tabular}{|c|c|c|c|c|c|c|}
\hline & & Pesticida & Frutas & Notif & \multicolumn{2}{|c|}{ Codex } \\
\hline & & & & & Consta & Não Consta \\
\hline \multirow{11}{*}{2004} & \multirow{8}{*}{1} & fenpropimorph & \multirow[b]{8}{*}{ fruits } & & foi revogado & \\
\hline & & myclobutanil & & & + & \\
\hline & & chlorothalonil & & & + & \\
\hline & & methomyl & & & + & \\
\hline & & metalaxyl & & & + & \\
\hline & & penconazole & & & + & \\
\hline & & azoxystrobin & & & & + \\
\hline & & fenhexamid & & & & + \\
\hline & $2 * *$ & & & & & \\
\hline & 3 & $\begin{array}{c}\text { só cita a imporntância } \\
\text { de LMR }\end{array}$ & & & & \\
\hline & 4 & fenamiphos & & & & + \\
\hline
\end{tabular}

Quadro 1 - Análise das notificações de LMR relacionadas a frutas para a UE de 1999 até outubro de 2004

** há a relação de muitos pesticidas e frutas numa mesma notificação, alguns constam 


\section{ANEXO A - ANÁLISE DAS NOTIFICAÇÕES DE LMR}

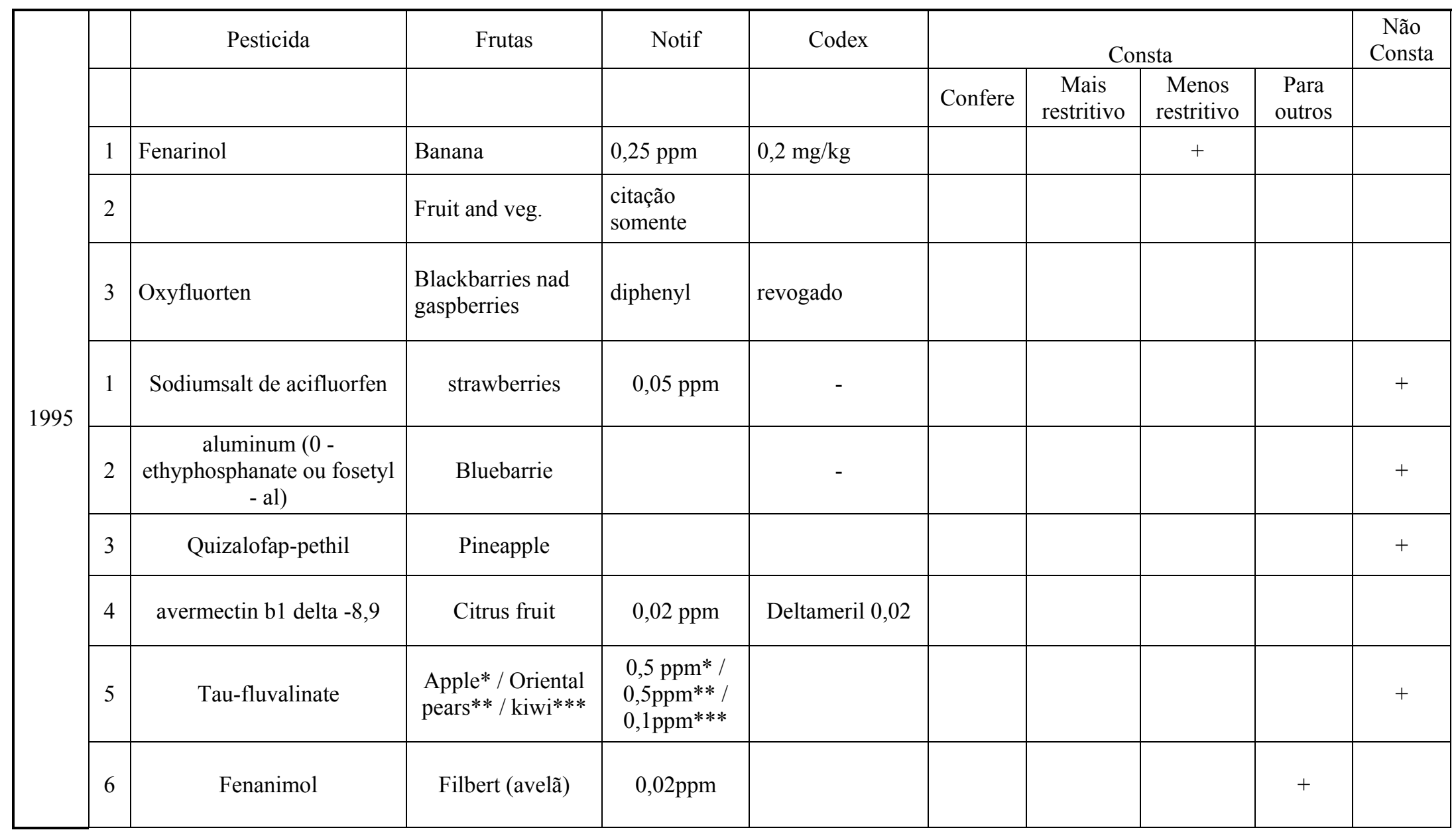




\begin{tabular}{|c|c|c|c|c|c|c|c|c|c|c|}
\hline & & \multirow[t]{2}{*}{ Pesticida } & \multirow[t]{2}{*}{ Frutas } & \multirow[t]{2}{*}{ Notif } & \multirow[t]{2}{*}{ Codex } & \multicolumn{4}{|c|}{ Consta } & \multirow[t]{2}{*}{$\begin{array}{l}\text { Não } \\
\text { Consta }\end{array}$} \\
\hline & & & & & & Confere & $\begin{array}{l}\text { Mais } \\
\text { restritivo }\end{array}$ & $\begin{array}{l}\text { Menos } \\
\text { restritivo }\end{array}$ & $\begin{array}{l}\text { Para } \\
\text { outros }\end{array}$ & \\
\hline 1995 & 7 & Cyfluthrin pyrefhroid & Citrus fruits & $0,2 \mathrm{ppm}$ & & & & & + & \\
\hline 1997 & 1 & $\begin{array}{l}\text { Hydroprene/Trimethyl/Dod } \\
\text { ecadienoate }\end{array}$ & Fruits & $0,2 \mathrm{ppm}$ & & & & & & + \\
\hline \multirow{4}{*}{1999} & 1 & diphenylamine & Pears & $10 \mathrm{ppm}$ & $5 \mathrm{mg} / \mathrm{kg}$ & & & $\begin{array}{c}+/ \text { Doc. } \\
2004\end{array}$ & & \\
\hline & 2 & Cironazine & Mango & $0,3 \mathrm{ppm}$ & & & & & + & \\
\hline & 3 & Spinosad e Tetra conazole & & $\begin{array}{l}\text { Frutas } \\
\text { Tropicais }\end{array}$ & & & & & + & \\
\hline & 4 & n-pesticidas & & $\begin{array}{l}\text { somente } \\
\text { citação }\end{array}$ & & & & & & + \\
\hline
\end{tabular}




\begin{tabular}{|c|c|c|c|c|c|c|c|c|c|c|}
\hline & & Pesticida & Frutas & Notif & Codex & & $\mathrm{Co}$ & & & $\begin{array}{c}\text { Não } \\
\text { Consta }\end{array}$ \\
\hline & & & & & & Confere & $\begin{array}{c}\text { Mais } \\
\text { restritivo }\end{array}$ & $\begin{array}{c}\text { Menos } \\
\text { restritivo }\end{array}$ & $\begin{array}{c}\text { Para } \\
\text { outros }\end{array}$ & \\
\hline & 1 & $\begin{array}{l}\text { phosphorous e } \\
\text { cloropyridazin }\end{array}$ & Fruits & $0,2 \mathrm{ppm}$ & & & & & & + \\
\hline & 2 & $\begin{array}{l}\text { dimethyl benzol } \\
\text { /hydrazide/phosphonametil } \\
\text { glycine }\end{array}$ & Fruits & & & & & & & + \\
\hline & 3 & Phosphorus & Fruits & & & & & & & + \\
\hline & 4 & Trifloxitrobin & Fruits & $2.5 \mathrm{ppm}$ & & & & & & + \\
\hline & 5 & Imidracloprid & Citrus & $0,7 \mathrm{ppm}$ & $1,0 \mathrm{mg} / \mathrm{Kg}$ & & + & & & \\
\hline & 6 & Deltamethrin & pome fruit & & & + & & & & \\
\hline 2000 & 7 & flufenacet * & & & & & & & & \\
\hline & 8 & Clethodim & & & foi revogado & & & & & \\
\hline & 9 & Fludioxonil & strawberrie & & & & & & & + \\
\hline & 10 & Ethanadiamine & Fruits & & & & & & & + \\
\hline & 11 & Uréia & Fruits & & & & & & & + \\
\hline & & nitric acid & Fruits & & & & & & & + \\
\hline & 12 & Dimethomorph & grapes & $3,5 \mathrm{ppm}$ & & & & & & + \\
\hline & 13 & n-pesticidas* & & & & & & & & + \\
\hline & 14 & Methylparation & fruits & & & & & & & + \\
\hline & & Paraquat & frutas & $0.05 \mathrm{ppm}$ & \begin{tabular}{|l|}
0.02 \\
(passionfruits)
\end{tabular} & & & + & & \\
\hline & 15 & Fosety & crawberries & $0.05 \mathrm{ppm}$ & & & & & & + \\
\hline & & Cyprodinil & strawberries & $5.0 \mathrm{ppm}$ & $2.0 \mathrm{mg} / \mathrm{Kg}$ & & & + & & \\
\hline
\end{tabular}




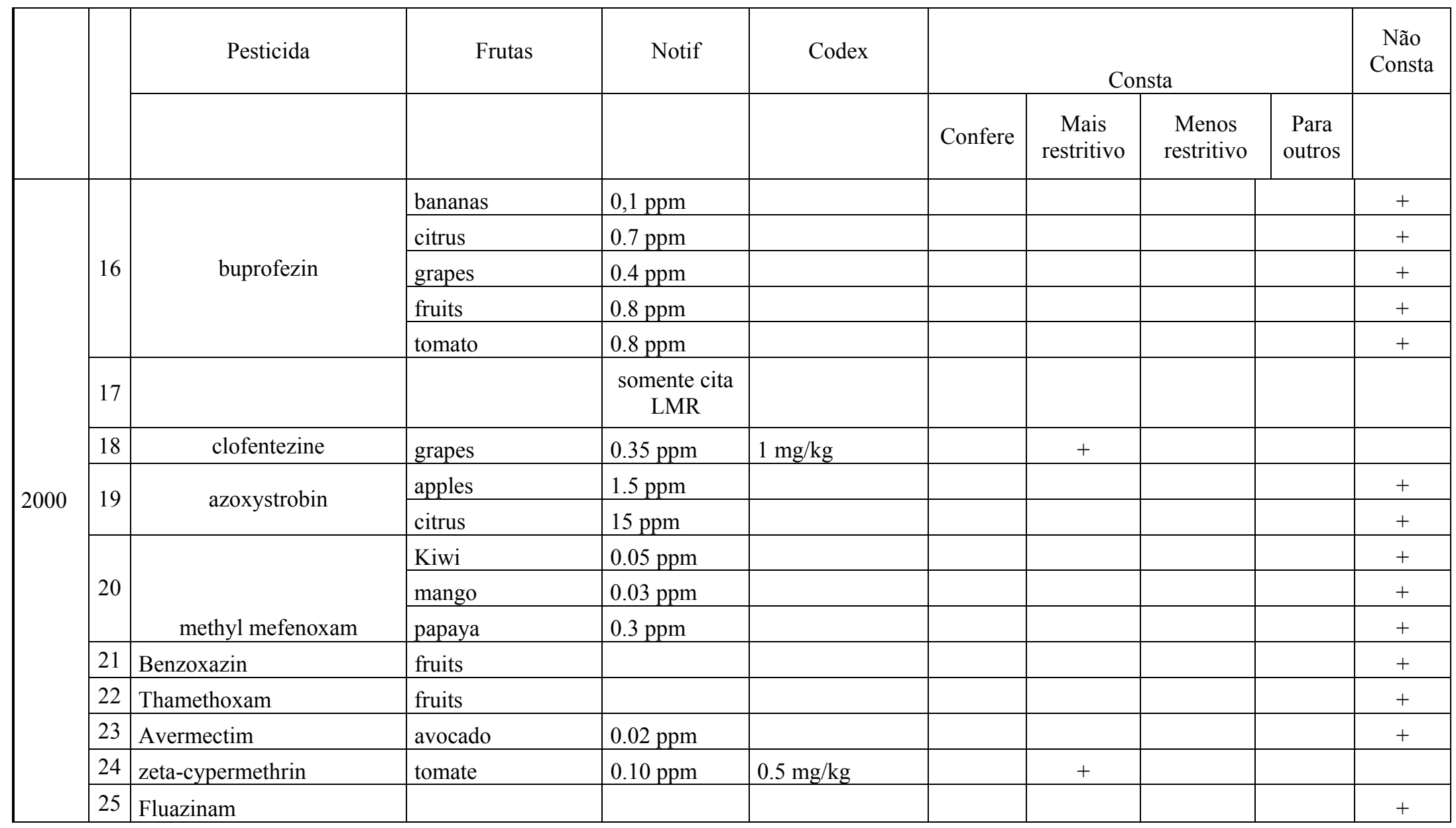




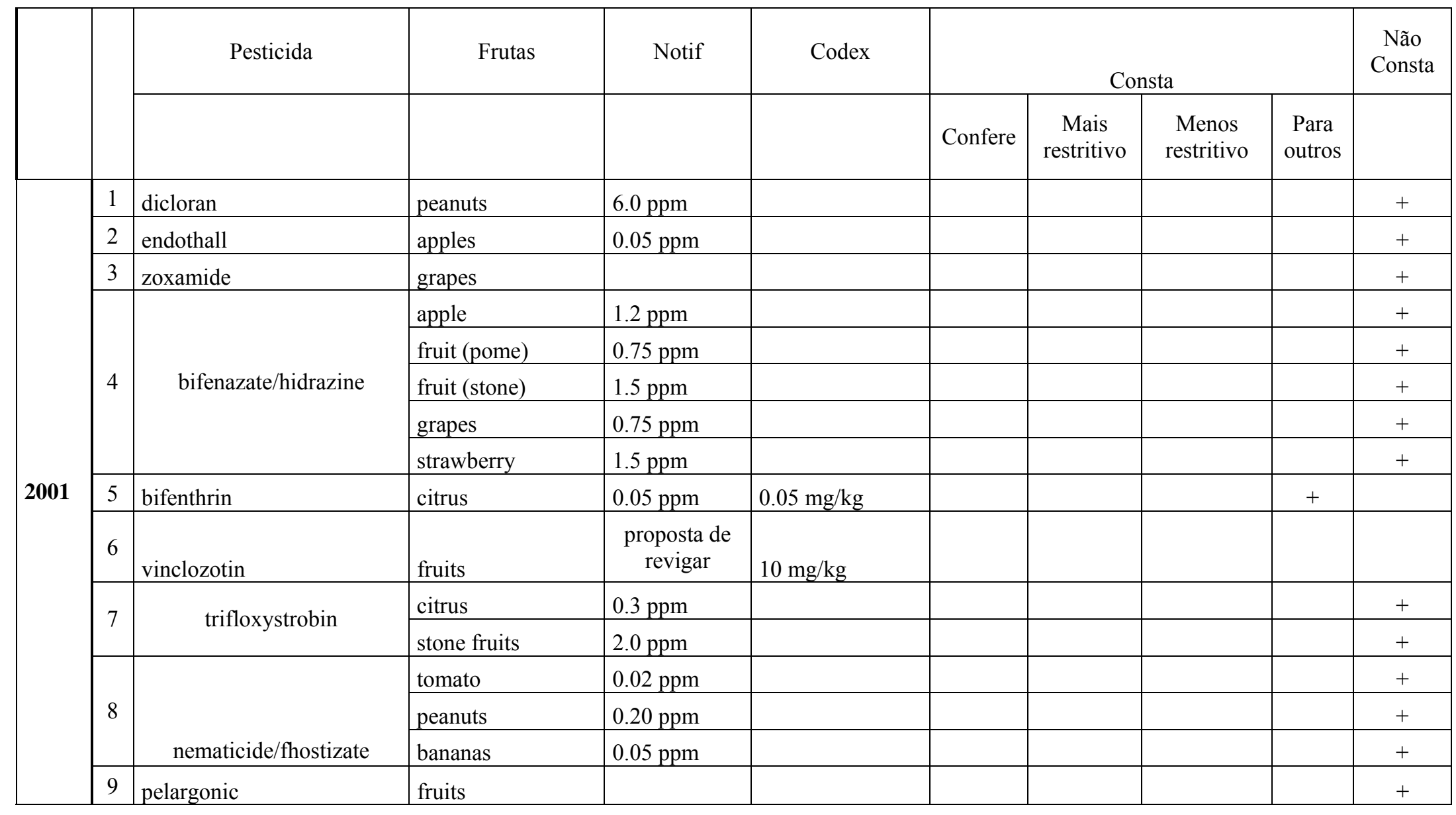




\begin{tabular}{|c|c|c|c|c|c|c|c|c|c|c|}
\hline & & Pesticida & Frutas & Notif & Codex & \multicolumn{4}{|c|}{ Consta } & $\begin{array}{l}\text { Não } \\
\text { Consta }\end{array}$ \\
\hline & & & & & & Confere & $\begin{array}{l}\text { Mais } \\
\text { restritivo }\end{array}$ & $\begin{array}{l}\text { Menos } \\
\text { restritivo }\end{array}$ & $\begin{array}{l}\text { Para } \\
\text { outros }\end{array}$ & \\
\hline \multirow{6}{*}{2002} & 1 & fenamidone & tomatos & $1.0 \mathrm{ppm}$ & & & & & & + \\
\hline & 2 & indoxcarb & peanuts & $0.01 \mathrm{ppm}$ & & & & & & + \\
\hline & 3 & fenhaxamid & pistachio & $0.5 \mathrm{ppm}$ & & & & & & + \\
\hline & & \multirow{3}{*}{ bifenthrin } & pears & $1.0 \mathrm{ppm}$ & $0.5 \mathrm{mg} / \mathrm{kg}$ & & & + & & \\
\hline & 4 & & tomato & $0.15 \mathrm{ppm}$ & & & & & & + \\
\hline & & & carambola & $1.0 \mathrm{ppm}$ & & & & & & + \\
\hline \multirow{13}{*}{2003} & 1 & uréia & fruits & revogar & & & & & & \\
\hline & \multirow{4}{*}{2} & \multirow[b]{4}{*}{ pyriproxyfen } & apples & $0.20 \mathrm{ppm}$ & & & & & + & \\
\hline & & & avocado & $1.0 \mathrm{ppm}$ & & & & & + & \\
\hline & & & mango & $1.0 \mathrm{ppm}$ & & & & & + & \\
\hline & & & papaya & $1.0 \mathrm{ppm}$ & & & & & + & \\
\hline & 3 & cyazofamid & tomatos & $0.2 \mathrm{ppm}$ & & & & & & + \\
\hline & 4 & metolachlos Acetamid & tomatos & $0.1 \mathrm{ppm}$ & & & & & & + \\
\hline & \multirow{2}{*}{5} & \multirow{2}{*}{ Thiacloprid } & apple & $0.6 \mathrm{ppm}$ & & & & & & + \\
\hline & & & fruit stone & $0.5 \mathrm{ppm}$ & & & & & & + \\
\hline & 6 & hexythiozox & dried fruits & $1.0 \mathrm{ppm}$ & & & & & + & \\
\hline & \multirow{3}{*}{7} & \multirow{3}{*}{ flonicamid } & pome friut & $0.2 \mathrm{ppm}$ & & & & & & + \\
\hline & & & stone fruits & $0.7 \mathrm{ppm}$ & & & & & & + \\
\hline & & & tomato & $0.5 \mathrm{ppm}$ & & & & & & + \\
\hline
\end{tabular}




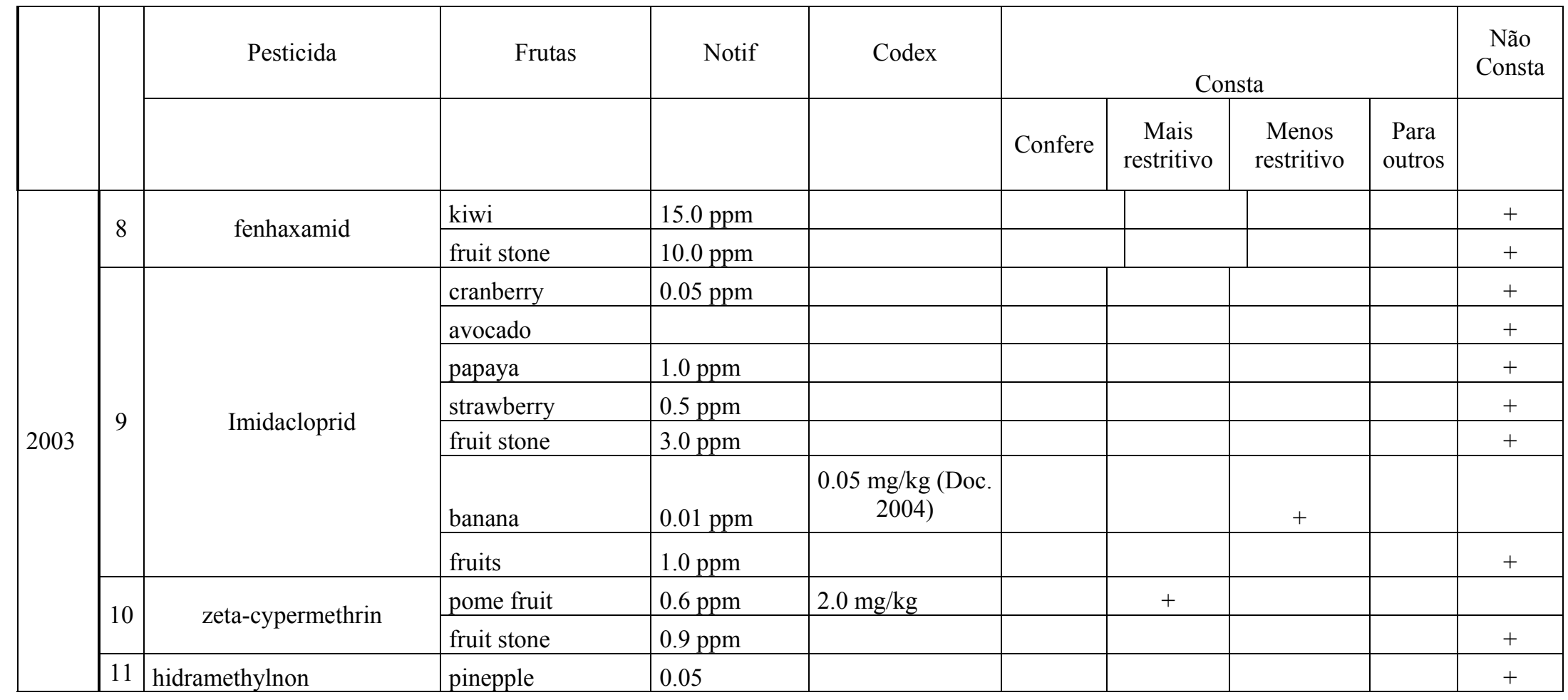




\begin{tabular}{|c|c|c|c|c|c|c|c|c|c|c|}
\hline & & Pesticida & Frutas & Notif & Codex & \multicolumn{4}{|c|}{ Consta } & \multirow[t]{2}{*}{$\begin{array}{l}\text { Não } \\
\text { Consta }\end{array}$} \\
\hline & & & & & & Confere & $\begin{array}{l}\text { Mais } \\
\text { restritivo }\end{array}$ & $\begin{array}{l}\text { Menos } \\
\text { restritivo }\end{array}$ & $\begin{array}{l}\text { Para } \\
\text { outros }\end{array}$ & \\
\hline \multirow{12}{*}{2003} & \multirow{4}{*}{12} & \multirow{4}{*}{ etoxazole } & pome fruit & $0.2 \mathrm{ppm}$ & & & & & & + \\
\hline & & & apple & $1.0 \mathrm{ppm}$ & & & & & & + \\
\hline & & & strawberry & $0.5 \mathrm{ppm}$ & & & & & & + \\
\hline & & & orange & $0.10 \mathrm{ppm}$ & & & & & & + \\
\hline & \multirow{2}{*}{13} & \multirow{2}{*}{ dimethomorph } & tomato & $0.5 \mathrm{ppm}$ & & & & & & + \\
\hline & & & fruits & $0.5 \mathrm{ppm}$ & & & & & & + \\
\hline & 14 & thiamexotan & stone fruits & & & & & & & + \\
\hline & 15 & trifloxysulfuron & citrus & $10 \mathrm{ppm}$ & & & & & & + \\
\hline & 16 & bifenazate & pistachio & $0.20 \mathrm{ppm}$ & & & & & & + \\
\hline & 17 & aviglycine $\mathrm{HCI}$ & apples and pears & & & & & & & + \\
\hline & \multirow{2}{*}{18} & \multirow{2}{*}{ aviglycine $\mathrm{HCI}$} & stone fruits & & & & & & & + \\
\hline & & & cherries & & & & & & & + \\
\hline \multirow{5}{*}{2004} & \multirow{5}{*}{1} & \multirow{5}{*}{ Cyfluthrin } & pistachio & 0.01 & & & & & & + \\
\hline & & & pome fruit & 0.10 & 0.5 & & + & & & \\
\hline & & & stone fruits & 0.30 & & & & & & + \\
\hline & & & grapes & 0.8 & & & & & & + \\
\hline & & & peanuts & 6.0 & & & & & & + \\
\hline
\end{tabular}




\begin{tabular}{|c|c|c|c|c|c|c|c|c|c|c|}
\hline & & \multirow[t]{2}{*}{ Pesticida } & \multirow[t]{2}{*}{ Frutas } & \multirow[t]{2}{*}{ Notif } & \multirow[t]{2}{*}{ Codex } & \multicolumn{4}{|c|}{ Consta } & \multirow[t]{2}{*}{$\begin{array}{l}\text { Não } \\
\text { Consta }\end{array}$} \\
\hline & & & & & & Confere & $\begin{array}{l}\text { Mais } \\
\text { restritivo }\end{array}$ & $\begin{array}{l}\text { Menos } \\
\text { restritivo }\end{array}$ & $\begin{array}{l}\text { Para } \\
\text { outros }\end{array}$ & \\
\hline & \multirow{5}{*}{2} & \multirow{5}{*}{ spirodiclofen } & citrus & & & & & & & + \\
\hline & & & pome fruit & & & & & & & + \\
\hline & & & stone fruits & & & & & & & + \\
\hline & & & pistachio & & & & & & & + \\
\hline & & & grapes & & & & & & & + \\
\hline \multirow{18}{*}{2004} & 3 & acequinocyl & fruit & & & & & & & + \\
\hline & \multirow{3}{*}{4} & \multirow[b]{3}{*}{ novaluron } & apple & $6.0 \mathrm{ppm}$ & & & & & & + \\
\hline & & & pears & & & & & & & + \\
\hline & & & pome fruit & $1.0 \mathrm{ppm}$ & & & & & & + \\
\hline & \multirow{4}{*}{5} & \multirow[b]{4}{*}{ indixacarb } & kiwi & & & & & & & + \\
\hline & & & pome fruit & & & & & & & + \\
\hline & & & melon & & & & & & & + \\
\hline & & & citrus & & & & & & & + \\
\hline & 6 & $\begin{array}{c}\text { bromoxynil/picloran/paraqu } \\
\text { at }\end{array}$ & & & & + & & & & \\
\hline & 7 & forchlorfeuron & fruits & $0.01 \mathrm{ppm}$ & & & & & & + \\
\hline & 8 & apergillus & peanuts & & & & & & & + \\
\hline & 9 & indoxcarb & cherries & & & & & & & + \\
\hline & & & & & & & & & & \\
\hline & 10 & imidacloprid & Bluebarry & $3.5 \mathrm{ppm}$ & & & & & + & \\
\hline & 11 & spinosad & peanuts & & & & & & + & \\
\hline & \multirow{2}{*}{12} & \multirow{2}{*}{ Pyridaben } & apricot & & & & & & & + \\
\hline & & & cherries & & & & & & & + \\
\hline & 13 & Mesotrione & crawberries & & & & & & & + \\
\hline
\end{tabular}

Quadro 2 - Análise das notificações de LMR relacionadas a frutas para os EUA de 1995 até outubro de 2004 


\section{ANEXO B - Modelo de Avaliação de Conformidade do Sistema PIF Brasil}

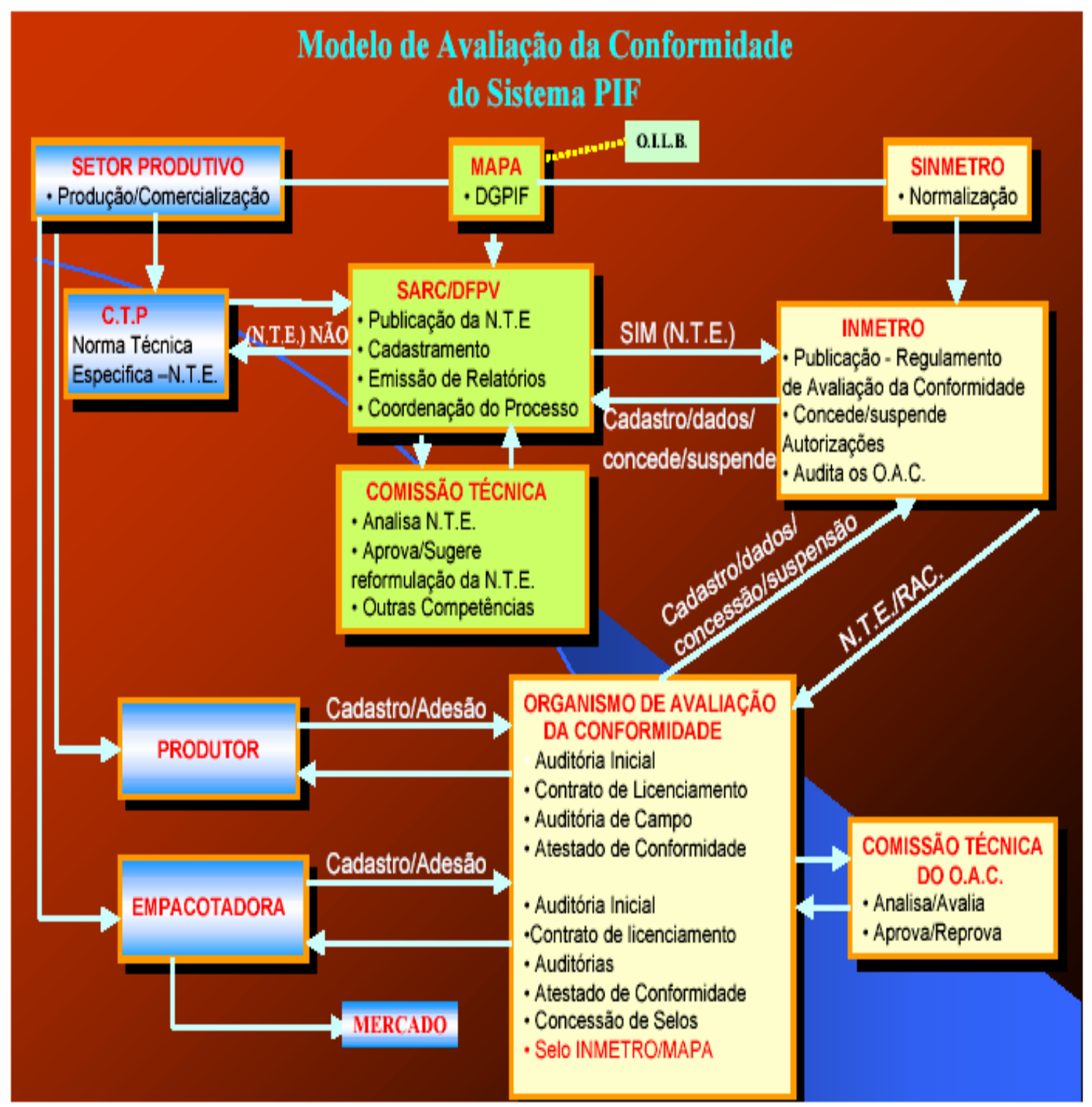




\section{ANEXO C - Glossário: significado de termos importantes para a implementação do PIF no Brasil (INMETRO, 2004)}

Avaliação de conformidade - Conformity Assessment, definida como qualquer atividade com o objetivo de determinar, direta ou indiretamente, que um produto, processo, pessoa ou serviço atende aos requisitos (itens ou critérios definidos em uma norma técnica, regulamento técnico ou outro documento de referência) especificados. Avaliação de conformidade a especificações, normas e/ou regulamentos técnicos pode ser realizada pelo uso de ferramentas como: ensaios*, inspeção, coleta de amostras no fornecedor e/ou comércio de auditorias, que é o exame sistemático e independente para verificar se as atividades e seus resultados estão em conformidade com requisitos especificados e objetivos planejados;

Certificação - Conjunto de atividades realizadas por uma organização independente, normalmente denominadas Organismos de Certificação (OC) ou organismos de certificação credenciados (OCC), quando são credenciados por um organismo de credenciamento, por exemplo, no âmbito do SINMETRO, o organismo credenciador é o INMETRO, para atestar e declarar que um produto, serviço, pessoa ou sistema está em conformidade com requisitos técnicos especificados;

Credenciamento - Processo que estabelece um mecanismo par evidenciar que os laboratórios utilizam um sistema de qualidade e possuam competência técnica para realizar serviços de ensaios, assegurando a estes a capacidade em obter resultados de acordo com métodos e técnicas reconhecidos nacional e internacionalmente. No âmbito do Sistema Brasileiro de Certificação o organismo autorizado é o INMETRO, que credencia organismos de certificação de sistemas, produtos, serviços, pessoal e de treinamento, organismo de inspeção, laboratórios de ensaios e laboratórios de calibração;.

Ensaios- Trata-se de uma operação técnica que consiste na determinação de uma ou mais características de um dado produto, processo ou serviço, de acordo com o procedimento especificado. Pode ser realizado para atender a: um fornecedor que 
pretenda emitir uma declaração do fornecedor para demonstrar a conformidade de um produto com uma norma; um comprador ou usuário de um produto, o qual deseja ter certeza de que os requisitos de um produto estejam atendidos; um organismo certificador, cujo negócio seja indicar a conformidade de um produto com uma norma ou especificação;

Regulamentos Técnicos - São documentos adotados por uma autoridade com poder legal para tanto, que contém regras de caráter obrigatório, estabelecendo requisitos técnicos pela referência a normas técnicas ou a incorporação do seu conteúdo, no todo ou na parte. Visa assegurar aspectos relativos à saúde, à segurança, ao meio ambiente, ou à proteção do consumidor e da concorrência justa. Seu cumprimento é obrigatório, e o seu não cumprimento constitui uma ilegalidade com a correspondente punição. Podendo estabelecer procedimentos para a avaliação da conformidade ao regulamento, inclusive certificação compulsória. 


\section{ANEXO D - Normas do APHIS direcionadas ao Brasil}

BRAZIL, Federative Republic of

\begin{tabular}{|c|c|c|c|}
\hline \multicolumn{3}{|l|}{ From all states of Brazil: } & \multirow{2}{*}{\begin{tabular}{|l} 
From the state of Espinito \\
Santo Only:
\end{tabular}} \\
\hline ALL & NA & SAG & \\
\hline 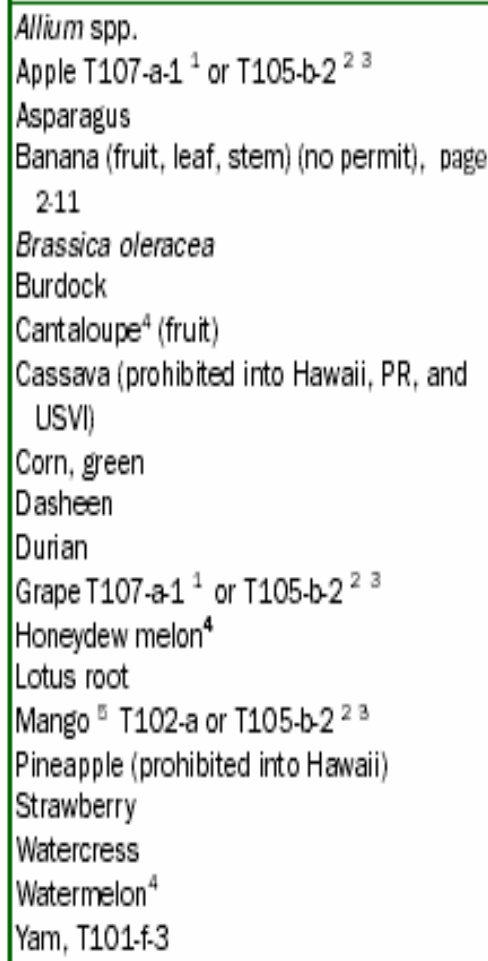 & $\begin{array}{l}\text { Artichoke, globe (immature } \\
\text { flower head) } \\
\text { Cacao bean pod } \\
\text { Lettuce } \\
\text { Okra (pod), page } 2.28 \\
\text { Pea (pod or shelled) } \\
\end{array}$ & $\begin{array}{l}\text { Lettuce } \\
\text { Okra (pod), } \\
\text { T101-p-2 }\end{array}$ & $\begin{array}{l}\text { Papaya (fruit) (Solo line or olo } \\
\text { cultivars such as Formosa or } \\
\text { Maradol) (prohibited into } \\
\text { Hawaii) }^{6}\end{array}$ \\
\hline
\end{tabular}

1 If treatment has not been completed before entry, the fruits or vegetables may arrive in the United States only at the following ports:

11/2004-39 Nonpropagative Manual 2-71

Any port located north of 39 o latitude and east of $104 \mathrm{o}$ longitude;

At one of the following maritime ports: Wilmington, NC; Seattle, WA; Corpus Christi, TX; and Gulfport, MS (not currently operational);

Seattle-Tacoma International, Seattle, WA (not currently operational);

Hartsfield-Atlanta International Airport, Atlanta, GA; and

Washington Dulles International Airport, Chantilly, VA 
2 Irradiation as an optional treatment is available only after an exporting country has entered into a framework equivalency work plan agreement and met other requirements as specified in 7CFR 305.2. Currently, this country has not entered into a work plan agreement.

3 Fruits irradiated in the country of origin and accompanied by a PPQ Form 203 to confirm irradiation may enter any State. However, untreated fruits and vegetables, intended to be irradiated for quarantine pests, cannot be treated within nor transit through the following States: Alabama, Arizona, California, Florida, Georgia (except for treatment in Atlanta, GA), Kentucky, Louisiana, Mississippi (except for treatment in Gulport, MS), Nevada, New Mexico, North Carolina (except for treatment in Wilmington, NC), South Carolina, Tennessee, Texas (except untreated products to be irradiated may transit through Dallas/Ft Worth) and Virginia.

4 Each shipment must be accompanied by a phytosanitary certificate issued by the Ministry of Agriculture for Brazil bearing the additional declaration: "Melons were produced in approved Anastrepha grandis-free production areas near Mossoro".

5 Mangoes must be treated with a hot water dip at an APHIS approved facility in Brazil. Each box must be marked with the statement: "APHIS-USDA TREATED WITH HOT WATER." The shipment must be accompanied by the original copy of the PPQ Form 203 completed and signed by the APHIS officer on site in Brazil.

6 May only come from the state of Espirito Santo and must be accompanied by a phytosanitary certificate declaring that "The papayas in this shipment were grown, packed, and shipped in accordance with the provisions of 7CFR 319.56-2(w).” 


\section{ANEXO E - Modelo de Notificação}

WORLD TRADE

ORGANIZATION

G/SPS/N/USA/959

24 August 2004

(04-3542)

Committee on Sanitary and Phytosanitary Measures

Original:

English

\section{NOTIFICATION}

1. Member to Agreement notifying: UNITED STATES

If applicable, name of local government involved:

2. Agency responsible: Environmental Protection Agency (EPA)

3. Products covered (provide tariff item number(s) as specified in national schedules deposited with the WTO; ICS numbers should be provided in addition, where applicable): Products that use the fungicide Forchlorfenuron such as almonds, apples, blueberries, cranberries, figs, grapes, kiwifruit, olives, pears and plums (fresh).

4. Regions or countries likely to be affected, to the extent relevant or practicable: Any U.S. trade partners.

5. Title, language and number of pages of the notified document: Final Rule. Forchlorfenuron; N-(2-chloro-4-pyridinyl)-N-phenylurea; Time Limited Pesticide Tolerance (Available in English; 7 pages).

6. Description of content: This final rule establishes a time limited tolerance for residues of forchlorfenuron; N-(2-chloro-4-pyridinyl)-N-phenylurea in or on almonds, apples, blueberries, cranberries, figs, grapes, kiwifruit, olives, pears and plums (fresh) at $0.01 \mathrm{ppm}$. The tolerance will expire on 31 May 2006.

7. Objective and rationale: [X] food safety, [ ] animal health, [ ] plant protection, $[\mathrm{X}$ ] protect humans from animal/plant pest or disease, [ ] protect territory from other damage from pests 


\begin{tabular}{|c|c|}
\hline 8. & $\begin{array}{l}\text { International standard, guideline or recommendation: } \\
\text { [ ] Codex Alimentarius Commission, [ ] World Organization for Animal } \\
\text { Health (OIE), [ ] International Plant Protection Convention, [X ] None } \\
\text { If an international standard, guideline or recommendation exists, give the } \\
\text { appropriate reference and briefly identify deviations: NA }\end{array}$ \\
\hline 9. & $\begin{array}{l}\text { Relevant documents and language(s) in which these are available: DOCID:fr, } \\
\text { Federal Register: } 11 \text { August } 2004 \text { (Volume 69, Number 154) Pages 48799- } \\
\text { 48805; } \quad \text { http://www.epa.gov/fedrgstr/EPA-PEST/2004/August/Day- } \\
\text { 11/p18383.htm (available in English). }\end{array}$ \\
\hline 10. & Propo \\
\hline 11. & Proposed date of entry into force: Not a \\
\hline 12. & $\begin{array}{l}\text { Final date for comments: } 11 \text { August } 2004 \text {. Objections and requests for } \\
\text { hearings must be received on or before } 12 \text { October 2004. EPA published a } \\
\text { notice pursuant to this action in the } 7 \text { April } 2004 \text { Federal Register. } \\
\text { Agency or authority designated to handle comments: [ X ] National notification } \\
\text { authority, [ ] National enquiry point, or address, fax number and E-mail } \\
\text { address (if available) of other body: } \\
\text { Registration Division ( } 7505 \mathrm{C} \text { ), Office of Pesticide Programs (OPP), } \\
\text { Environmental Protection Agency, } 1200 \text { Pennsylvania Ave., NW., } \\
\text { Washington, DC 20460. opp-docket@epa.gov Note: Identify docket name } \\
\text { "OPP-2004-0145" in subject line of your response. }\end{array}$ \\
\hline 13. & $\begin{array}{l}\text { Texts available from: [ ] National notification authority, [X] National } \\
\text { enquiry point, or address, fax number and E-mail address (if available) of other } \\
\text { body: } \\
\text { Ms. Julie Morin, United States SPS Enquiry Point Officer, USDA Foreign } \\
\text { Agricultural Service, Food Safety \& Technical Services Division, Stop 1027, } \\
\text { Washington D.C. 20250. Tel: 202-720-4051; Fax: 202-720-7772; Email: } \\
\text { fstsd@usda.gov }\end{array}$ \\
\hline
\end{tabular}




\section{ANEXO F - Estrutura do Sistema Brasileiro de Normalização}

Os principais organismos têm o seguinte papel: $\mathrm{O}$ inmetro é um órgão do Conmetro que foi instituído pelo Sinmetro, do MDIC, órgão nomeado pela presidência da República, com o intuito de acreditar processos onde se obtém produtos e serviços rastreáveis aos organismos aos quais ele foi acreditado. Ficou meio estranho esse começo.

Atualmente a cadeia de rastreabilidade mais importante do Inmetro é o ILAC (cerca de 140 países signatários). Assim, o Inmtero para o programa PIF, atua como órgão de acreditação de Organismos de certificação de Produtos (OCP'S).

A SGS, por exemplo, é um OCP acreditado pelo Inmetro que faz a certificação PIF. Todo o processo de certificação é baseado em auditorias e inspeções no sistema da qualidade montado a partir da cartilha do PIF (normas), que foram baseadas nas diretrizes do EUREPGAP ou EN 4500, ISO guia 65 ou do Codex Alimentarius. 

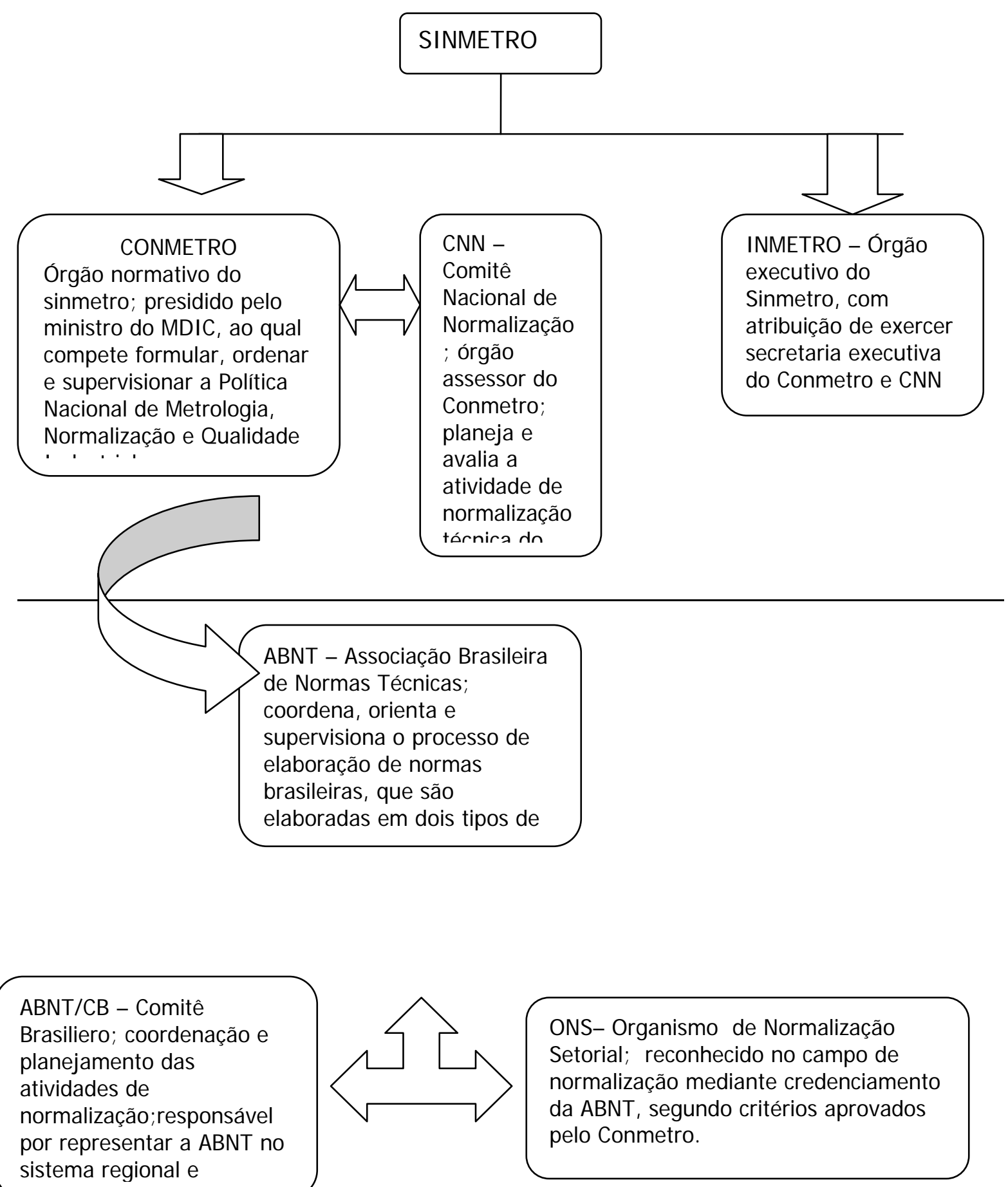

ONS- Organismo de Normalização Setorial; reconhecido no campo de normalização mediante credenciamento da ABNT, segundo critérios aprovados pelo Conmetro. 


\section{ANEXO G - Organismos internacionais importantes}

\begin{tabular}{|c|c|c|}
\hline Órgãos & Objetivos & Atuação \\
\hline $\begin{array}{l}\text { IOBC } \\
\text { International } \\
\text { Organisation for } \\
\text { Biological Control - } \\
\text { estabelecido em } \\
1956 \quad \text { como } \\
\text { organização global, } \\
\text { afiliado } \\
\text { International } \\
\text { Council of Scientific } \\
\text { Unions (ICSU). }\end{array}$ & $\begin{array}{l}\text { Promover pelo lado do meio } \\
\text { ambiente, métodos seguros de controle } \\
\text { de pestes e doenças; } \\
\text { Desenvolver o desenvolvimento do } \\
\text { controle biológico e aplicações nos } \\
\text { programas de gerenciamento de pestes } \\
\text { integradas, e corporações integradas } \\
\text { para esses estes fins; } \\
\text { Como uma Organização profissional } \\
\text { independente, pode ser um defensor } \\
\text { efetivo do controle biológico, e pode } \\
\text { influenciar os Governos e políticas; } \\
\text { Publicar um jornal para pesquisas } \\
\text { básicas e aplicadas no controle } \\
\text { biológico de vertebrados, invertebrados, } \\
\text { pestes daninhas e doenças de plantas. }\end{array}$ & $\begin{array}{l}\text { Coleta, avalia e dissemina informações } \\
\text { sobre o controle biológico, e promove } \\
\text { ação nacional e internacional } \\
\text { preocupando-se com pesquisas, treinando } \\
\text { pessoal, coordenando em larga escala } \\
\text { aplicação e publicação de anúncios da } \\
\text { importância social e econômica do } \\
\text { controle biológico; } \\
\text { Organiza conferências, encontro e } \\
\text { simpósios e pega outras informações para } \\
\text { implementar os objetivos gerais da } \\
\text { Organização; comunicação entre } \\
\text { Assiste na controle biológico, } \\
\text { trabalhadores de } \\
\text { através da difusão da IOBC Newsletter. }\end{array}$ \\
\hline $\begin{array}{l}\text { IAF- International } \\
\text { Accreditation } \\
\text { Forum - } \\
\text { Organização } \\
\text { voluntária } \\
\text { internacional } \\
\text { composta, } \\
\text { principalmente, por } \\
\text { organismos de } \\
\text { credenciamento em } \\
\text { avaliação de } \\
\text { conformidade. }\end{array}$ & $\begin{array}{l}\text { Promover o reconhecimento mútuo dos } \\
\text { sistemas nacionais e regionais de } \\
\text { avaliação da conformidade } \\
\text { desenvolver um programa mundial de } \\
\text { avaliação de conformidade para } \\
\text { promover a eliminação de barreiras não- } \\
\text { tarifárias ao comércio. }\end{array}$ & $\begin{array}{l}\text { Avaliação da Conformidade: } \\
\text { Promover a elaboração de acordos de } \\
\text { reconhecimento mútuo, memorandos de } \\
\text { entendimento e aceitação de certificados } \\
\text { de conformidade emitidos pelos seus } \\
\text { membros; } \\
\text { Desenvolver diretrizes } \\
\text { harmonização de sistemas de } \\
\text { credenciamento e certificação; } \\
\text { Estimular e apoiar o desenvolvimento } \\
\text { de organismos de credenciamento em } \\
\text { países que não os tenham. }\end{array}$ \\
\hline
\end{tabular}




\section{ANEXO G - Organismos internacionais importantes}

\begin{tabular}{|c|c|c|}
\hline Órgãos & Objetivos & Atuação \\
\hline $\begin{array}{l}\text { IATCA- } \\
\text { International } \\
\text { Auditor } \\
\text { Tranining } \\
\text { Certification }\end{array}$ & $\begin{array}{l}\text { Uniformizar programas internacionais } \\
\text { de treinamento e de registro de auditores } \\
\text { estabelecendo bases para acordos } \\
\text { mútuos de reconhecimento. Cooperando } \\
\text { com várias outras organizações } \\
\text { internacionais envolvidas com avaliação } \\
\text { de conformidade e com organismos de } \\
\text { certificação. }\end{array}$ & $\begin{array}{l}\text { Avaliação da Conformidade: } \\
\text { Definição de bases para atuação, } \\
\text { treinamento e registro de auditores com o } \\
\text { objetivo de ampliar a credibilidade de } \\
\text { avaliações de conformidade, as quais } \\
\text { usam a auditoria como elemento de } \\
\text { verificação da conformidade. }\end{array}$ \\
\hline $\begin{array}{l}\text { Cooperation } \\
\text { Cooperação } \\
\text { Internacional } \\
\text { Credenciamento } \\
\text { Laboratórios }\end{array}$ & 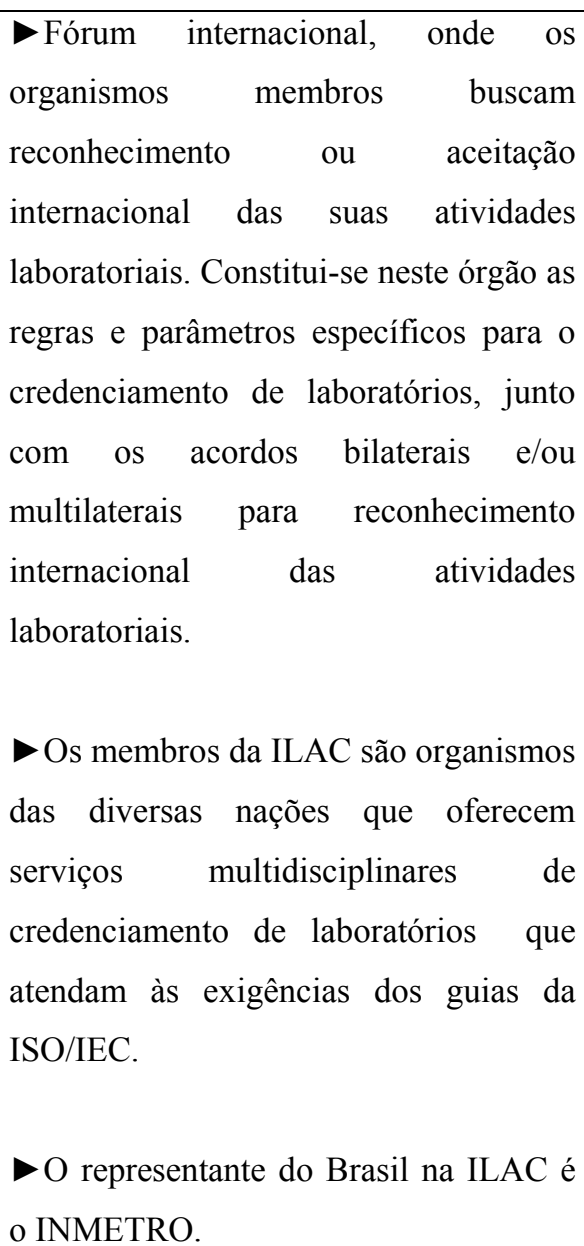 & $\begin{array}{l}\text { Normalização: harmonizar procedimentos } \\
\text { operacionais dos organismos de } \\
\text { credenciamento participantes. } \\
\text { Metrologia: promover o uso dos } \\
\text { laboratórios credenciados, abrindo e } \\
\text { mantendo canais para o fluxo das } \\
\text { informações. } \\
\text { Avaliação da Conformidade: incentivar o } \\
\text { desenvolvimento de cooperações } \\
\text { regionais; promover o avanço e a } \\
\text { aceitação de acordos de reconhecimento } \\
\text { mútuo; ajudar os organismos de } \\
\text { credenciamento interessados } \\
\text { desenvolvimento de seus sistemas e } \\
\text { cooperar com outros organismos } \\
\text { nacionais, regionais ou internacionais com } \\
\text { objetivos similares e complementares. }\end{array}$ \\
\hline
\end{tabular}




\section{ANEXO G - Organismos internacionais importantes}

\begin{tabular}{|c|c|c|}
\hline Órgãos & Objetivos & Atuação \\
\hline $\begin{array}{l}\text { IAAC } \\
\text { Interamerican } \\
\text { Accreditation } \\
\text { Cooperation. Criada } \\
\text { em 1996, congrega } \\
\text { organismos de } \\
\text { credenciamento das } \\
\text { Américas nos } \\
\text { seguintes escopos: } \\
\text { certificação, } \\
\text { inspeção, } \\
\text { laboratórios } \\
\text { calibração e ensaios. }\end{array}$ & $\begin{array}{l}\text { Facilitar trocas comerciais entre as } \\
\text { nações e blocos de nações nas Américas } \\
\text { através da discussão e troca de } \\
\text { experiências nas atividades de } \\
\text { credenciamento como primeiro estágio } \\
\text { do desenvolvimento das bases do } \\
\text { Acordo de Reconhecimento Mútuo } \\
\text { (Multilateral Recognition Agreement - } \\
\text { MRA), baseando-se em mecanismos } \\
\text { internacionalmente reconhecidos e } \\
\text { documentos de referência. }\end{array}$ & $\begin{array}{l}\text { Avaliação da Conformidade: } \\
\text { Dar suporte à Área de Livre Comércio } \\
\text { das Américas (ALCA) na eliminação de } \\
\text { barreiras técnicas relativas à avaliação da } \\
\text { conformidade através do Acordo de } \\
\text { Reconhecimento Mútuo entre organismos } \\
\text { de credenciamento; } \\
\text { Dar suporte ao mercado nas demandas } \\
\text { do Acordo de Reconhecimento Mútuo; } \\
\text { Manter a equivalência dos programas } \\
\text { de credenciamento de organismos para: } \\
\text { sistemas da qualidade e ambiental, } \\
\text { produtos, pessoal, laboratórios de } \\
\text { calibração e de ensaios. }\end{array}$ \\
\hline
\end{tabular}




\section{ANEXO H - Quadro resumo da estrutura brasileira de normalização}

\begin{tabular}{|c|c|}
\hline $\begin{array}{l}\text { INMETRO - Instituto Nacional } \\
\text { de Metrologia, Normalização e } \\
\text { Qualidade Industrial }\end{array}$ & $\begin{array}{l}\text { INMETRO é um órgão governamental com a finalidade de formular e } \\
\text { executar a política nacional de metrologia, normalização industrial e } \\
\text { certificação de qualidade de produtos industriais. }\end{array}$ \\
\hline $\begin{array}{l}\text { ABNT - Associação Brasileira de } \\
\text { Normas Técnicas }\end{array}$ & $\begin{array}{l}\text { ABNT é uma entidade civil, sem fins lucrativos, credenciada como } \\
\text { único Fórum Nacional de Normalização, responsável pela elaboração } \\
\text { das normas brasileiras de caráter voluntário. }\end{array}$ \\
\hline $\begin{array}{lrr}\text { CONMETRO } & - & \text { Conselho } \\
\text { Nacional de } & \text { Metrologia, } \\
\text { Normalização } & \text { e } & \text { Qualidade } \\
\text { Industrial } & & \end{array}$ & $\begin{array}{l}\text { Órgão político central do SINMETRO, do qual participam oito } \\
\text { ministérios, a ABNT - Associação Brasileira de Normas Técnicas, o } \\
\text { IDEC - Instituto Brasileiro de Defesa do Consumidor e a CNI - } \\
\text { Confederação Nacional da Indústria, sendo presidido pelo Ministério } \\
\text { do Desenvolvimento, Indústria e Comércio Exterior e secretariado } \\
\text { pelo INMETRO }\end{array}$ \\
\hline $\begin{array}{l}\text { SINMETRO - Sistema Nacional } \\
\text { de Metrologia, Normalização e } \\
\text { Qualidade Industrial }\end{array}$ & $\begin{array}{l}\text { Criado em 1973, tem como finalidade o desenvolvimento e } \\
\text { implementação da política nacional de metrologia, normalização e } \\
\text { avaliação da qualidade industrial. Qualquer entidade pública ou } \\
\text { privada que exerça atividade relacionada aos assuntos pode integrar- } \\
\text { se ao SINMETRO. Possui como órgão normativo o CONMETRO e } \\
\text { como órgão executivo o INMETRO. }\end{array}$ \\
\hline $\begin{array}{l}\text { SBC - Sistema Brasileiro de } \\
\text { Certificação }\end{array}$ & $\begin{array}{l}\text { Conjunto de organizações, atividades, regras e procedimento } \\
\text { reconhecido pelo governo brasileiro para garantir a transparência e } \\
\text { credibilidade da atividade de certificação e atividades correlatas. O } \\
\text { órgão executivo do SBC é o INMETRO }\end{array}$ \\
\hline Sistema de Certificado OIML & $\begin{array}{l}\text { Sistema possibilita a qualquer fabricante de um instrumento de } \\
\text { medição, associado à metrologia legal, solicitar um certificado OIML } \\
\text { a um estado membro que faça parte do sistema (no caso do Brasil, o } \\
\text { INMETRO). Os ensaios são realizados de acordo com as } \\
\text { recomendações da OIML em laboratórios designados pela autoridade } \\
\text { emissora do certificado. Esses laboratórios devem satisfazer aos } \\
\text { requisitos da NBR ISO/IEC } 17025 \text { e outros documentos apropriados. } \\
\text { O certificado deve ser registrado no BIML, que é o responsável pelo } \\
\text { envio de cópias aos países membros da OIML e pela publicação no } \\
\text { boletim OIML. }\end{array}$ \\
\hline
\end{tabular}


ANEXO H - Quadro resumo da estrutura brasileira de normalização

\begin{tabular}{|ll|l|}
\hline SI - Sistema Internacional de & Sistema coerente de unidades adotado e recomendado pela CGPM
\end{tabular} Unidades (VIM

O SI foi ratificado pela $11^{\mathrm{a}} \mathrm{CGPM} / 1960$ e atualizado até a $20^{\mathrm{a}}$ CGPM/1995.

Fonte: INMETRO (2004) 


\section{REFERÊNCIAS BIBLIOGRÁFICAS}

ADUANEIRAS. Barreiras a produtos e restrições a serviços e investimentos nos EUA. 3.ed. São Paulo: Edições Aduaneiras Ltda., nov. 2003. 167p.

ANDRIGUETO, J.R. Conferência internacional sobre rastreabilidade de alimentos. Produção integrada (compact disc). In: CURSO INTERNACIONAL SOBRE O PROTOCOLO EUROPEU E DE BOAS PRÁTICAS AGRÍCOLAS, 1., Bento Gonçalves, 2000. Anais. Jaguariúna: Embrapa, 2001.

ANDRIGUETO, J.R. Desenvolvimento e conquistas da produção integrada de frutas no Brasil (compact disc). In: EMPRESA BRASILEIRA DE PESQUISA AGROPECUÁRIA. Meio Ambiente. Formação de inspetores para atuação no Brasil de acordo com o Protocolo Europeu de Boas Práticas Agrícolas e Qualidade do Produto (EUREPGAP+BRC). Jaguariúna, 2004.

ANIMAL AND PLANT HEALTH INSPECTION SERVICE (APHIS). Programs. http://www.aphis.usda.br (20 Oct. 2004)

ANTLE, J.M. Benefits and costs of food safety regulation. Food Policy, v.3, n.4, p.605623, 1999.

ASSOCIAÇÃO BRASILEIRA DE NORMAS TÉCNICAS (ABNT). Normalização/institucional. http://www.abnt.org.br (18 out. 2004)

ATHUKORALA, P.C.; JAYASURIYA, S. Food safety issues, trade and WTO rules: a developing country perspective. The World Economy, v.26, n.9, p.154-167, Sep. 2003. 
BRASIL. Ministério da Agricultura Pecuária e Abastecimento. Estatísticas/agronegócio brasileiro. http://www.agricultura.gov.br (12 set. 2004a)

BRASIL. Ministério da Agricultura Pecuária e Abastecimento. Estatísticas/comércio exterior brasileiro. http://www.agricultura.gov.br (15 out. 2004b)

BRASIL. Ministério da Agricultura Pecuária e Abastecimento. Estatísticas/dados estatísticos. http://www.agricultura.gov.br (12 nov. 2004c)

BRASIL. Ministério da Agricultura Pecuária e Abastecimento. Estatísticas: programa de apoio à produção e exportação de frutas, hortaliças, flores e plantas ornamentais (FRUPEX). http://www.agricultura.gov.br (15 out. 2004d)

BRASIL. Ministério do Desenvolvimento da Indústria e Comércio. Secretaria de Comércio Exterior. Exportações brasileiras: 1999-2005 (13 nov. 2004e)

BRASIL. Ministério do Desenvolvimento da Indústria e Comércio. Secretaria de Comércio Exterior. Informativos técnicos. http://www.desenvolvimento.gov.br/sitio/secex/informativo (12 nov. 2004f)

BRASIL. Secretaria de Comércio Exterior. Sistema Aliceweb. http://www.portaldoexportador.gov.br (20 out. 2004g)

BRITISH RETAIL CONSORTIUM (BRC). BRC global standards and services. http://www.brc.org.uk (10 Nov. 2004)

CHAIM, A.M.C. Acordo de aceitação mútua de relatórios de ensaio e certificados de calibração entre signatários do Acordo Multilateral e o CODEX, Codex alimentarius: understanding codex. http:/www.codexalimentarius.net/web/index _officialsatandars (15 Sep. 2004)

CODEX ALIMENTARIUS (CODEX). Official standards. http://www.codexalimentarius.net.www.fao.org/documents/codex (15 Nov. 2004) 
DANKERS, C. The WTO and environmental and social standards, certification and labelling in agriculture. Genebra: Fao, Commodity And Trade Policy Research Working Raw Materials, Tropical and Horticultural Products Service (ESCR), Commodities and Trade Division, 2003. 47p. (Paper, 2/2003)

DEHAVEN, W. Animal and Plant Health Inspection Service. http://www.aphis.usda.gov (20 Mar. 2004)

DEODHAR, S.Y. WTO agreements on SPS and TBT: implications for food quality issues indian. Food Industry, v.20, n.3, p12-20, May/June 2001.

DIXIT, A.; NORMAN, V. Theory of international trade: a dual general equilibrium approach. Cambridge: Cambridge University Press, 1980. 339p.

EHLERS, E. Agriculturas sustentável: origens e perspectivas de um novo paradigma. São Paulo: Livros da Terra, 1996. 97p.

EMPRESA BRASILEIRA DE PESQUISA AGROPECUÁRIA. Meio Ambiente. Qualidade ambiental em fruticultura irrigada no nordeste brasileiro. Jaguariúna: EMBRAPA, CNPMA, Ecofrutas, 1999b. (Projeto 11.0.99.239)

EMPRESA BRASILEIRA DE PESQUISA AGROPECUÁRIA. Meio Ambiente. Qualidade ambiental em fruticultura irrigada no nordeste brasileiro. Jaguariúna; EMBRAPA, CNPMA, 2004c. http://www.cnpma.embrapa.br/projetos/prod_int. (20 out. 2004)

EMPRESA BRASILEIRA DE PESQUISA AGROPECUÁRIA. Qualidade ambiental em fruticultura irrigada no nordeste brasileiro. Petrolina: EMBRAPA, CNPMA, Ecofrutas, 2004a. http://www.embrapa.br/_(20 out. 2004)

EUREPGAP. The normative document for certification: EUREPGAP fruit and vegetables. http://www.eurep.org/fruit/index_html (20 Oct. 2004) 
FACHINELLO, A. Checkplant: rastreabilidade e segurança alimentar. http://www.checkplant.com.br (20 Oct. 2004)

FACHINELLO, J.C. Produção integrada de frutas (PIF) para frutas de qualidade. Pelotas: Faculdade de Agronomia Eliseu Maciel, Depto. Fitotecnia, ago. 2004. 63p.

FAO. FAOSTAT: crops \& liverstock primary processed. http://www.fao.org (20 Oct. 2004)

FEENSTRA, R.C. Advanced international trade: theory and evidence. Princeton: Princeton University Press, 2003. 496p.

FERMAN, R.K. A evolução do procedimento de notificação de normas e regulamentos técnicos na União Européia e seu papel na eliminação de barreiras técnicas. http://www.inmetro.gov.bt/barreirastecnicas/artigos (14 ago. 2004)

FERMAN, R.K. HACCPP e as barreiras técnicas. http://www.inmetro.gov.bt/barreirastecnicas/artigos (15 set. 2004)

FERRACIOLI, P. Negociações sobre barreiras técnicas. http://www.inmetro.gov.bt/barreirastecnicas/artigos (15 set. 2004)

FOOD AND DRUG ADMINISTRATION (FDA). Information. http://www.fda.gov (20 Oct. 2004)

GARRIDO, A.E. Barreiras técnicas ao comércio internacional. Rio de Janeiro, 2004. 103p. Dissertação (M.S.) - Universidade Federal Fluminense.

GRAF, H.G. Background analysis: trend extrapolation, analysis of framework, megatrend analysis. Cambridge: University of Cambridge, 2004. 15p.

HONG, W. International trade: a provisional lecture note. http://prome.snu.ac.kr/ wthong/trade/trdindex.html (10 Jan. 2005) 
ICONEBRASIL. Instituto de Estudos do Comércio e Negociações Internacionais: artigos/publicações. http://www.íconebrasil.org.br/index (20 out. 2004)

INSTITUTO NACIONAL DE METROLOGIA, NORMALIZAÇÃO E QUALIDADE INDUSTRIAL (INMETRO). Barreiras técnicas às exportações. http://www.inmetro.gov.br/artigos (20 out. 2004)

INTERNATIONAL ORGANIZATION STANDARDIZATION (ISO). ISO's structure. http//www.iso.org/iso/en/aboutiso/isostr.html (31 Jan. 2005)

JENSEN, M.F. Reviewing the SPS agreement: a developing country perspective CDR. Washington: USDA, Economic Research Service, Feb. 2002. (Working Paper, 02.3)

KOSOSKI, A.R. Projeto de avaliação da conformidade da produção integrada de frutas. Brasília: Ministério da Agricultura Pecuária e Abastecimento (MAPA), 2004. 9p.

KRUGMAN, P.R.; OBSTFELD, M. Internatonal economics: theory and policy. New York: Addison-Wesley, 1997. 795p.

LINDERT, P.H.; PUGEL, T.A. International economics. Homewood: Irwin Inc., 1996. $36 \mathrm{p}$.

MASKUS, K.; WILSON, J.; OTSUKi, T. Quantifying the impact of technical barriers to trade: a framework for analysis. Washington: World Bank, Jan. 2001. $33 p$.

MIRANDA, S.H.G.; CUNHA FILHO, J.H.; BURNQUIST, H.L.; BARROS, G.S.A.C. Normas sanitária e fitossanitárias: proteção ou protecionismo. Informações Econômicas, v.34, n.2, p.3-4, fev. 2004.

MORAES, M.V.P. Marco legal da produção integrada de frutas do Brasil. Brasília: Ministério da Agricultura, Pecuária e Abastecimento, set. 2002. 58p. 
OLIVEIRA, N.B. Barreiras invisíveis no comércio. Gazeta Mercantil, Brasília, 12 dez. 2002.

PESSOA, M.C.P.; SILVA, Y.P.; SOUZA, A. Eurep GAP-APPCC-campo. http://www.embrapa.br/mapa (20 out. 2004)

PRAZERES, T. Quando a segurança nacional serve para dissimular o protecionismo. Gazeta Mercantil, Brasília, 31 mar. 2003.

ROBERTS, D.; JOSLING, T.E.; ORDEN, D. A framework for analyzing technical trade barriers in agricultural markets. Washington: Department of Agriculture, Economic Research Service, Market and Trade Economics Division, Mar. 1999. 44p. (Technical Bulletin, 1876)

SILVA, A.S. Boas práticas de fabricação (BPF). http://www.embrapa.br/mapa (15 out. 2004)

SPERS, E.E.; KASSOUF, A.L. A segurança dos alimentos uma preocupação crescente. Piracicaba: Escola Superior de Agricultura "Luiz de Queiroz", Depto. Economia, Administração e Sociologia, ago. 1996. 74p.

TANNO, G. Etiquetagem e barreiras técnicas: posicionamento dos EUA e UE. http://www.inmetro.gov.br/barreirastécnicas/artigos (15 ago. 2004)

TANNO, G.; FERRACIOLLI, P. Barreiras técnicas o papel do Inmetro do GATTOMC. http://www.inmetro.gov.br/barreirastécnicas/artigo.asp (15 ago. 2004)

THORNSBURY, S. Technical regulations as barriers to agricultural trade. Virginia, 1998. 192p. Dissertation. (M.S.) - Virginia Polytechnic Institute and State University. 
THORNSBURY, S.; ROBERTS, D.; DEREMER, D.; ORDEN, D. A first step in understanding technical barriers to agricultural trade. In: INTERNATIONAL CONFERENCE OF AGRICULTURAL ECONOMISTS, Sacramento, 1997. Proceedings. Oxford: University of Oxford, 1999. p.453-464.

THORNSBURY, S.; ROBERTS, D.; ORDEN, D. Measurement and political economy of disputed technical regulations. Journal of Agricultural and Applied Economics, v.36, n.3, p.559-574, 2004.

THORSTENSENS, V. Organização mundial do comércio. São Paulo: Aduaneiras, 1996. 406p.

WILSON, J.S. Bridging the standards divide: recommendations for reform from a development perspective background paper for the World Development Report. Washington: The World Bank, Development Economics Research Group, Feb. 2001.21p. 